\title{
A Structural Integrity Assessment of the Tank Farm Waste Transfer System
}

\author{
B. J. Wiersma \\ Savannah River National Laboratory \\ Materials Science and Technology
}

Publication Date: March, 2006

\section{Westinghouse Savannah River Company} Savannah River Site

\section{Aiken, SC 29808}

This document was prepared in connection with work done under Contract No. DE-AC09-96SR18500 with the U. S. Department of Energy 


\section{DISCLAIMER}

This report was prepared as an account of work sponsored by an agency of the United States Government. Neither the United States Government nor any agency thereof, nor any of their employees, makes any warranty, express or implied, or assumes any legal liability or responsibility for the accuracy, completeness, or usefulness of any information, apparatus, product, or process disclosed, or represents that its use would not infringe privately owned rights. Reference herein to any specific commercial product, process, or service by trade name, trademark, manufacturer, or otherwise does not necessarily constitute or imply its endorsement, recommendation, or favoring by the United States Government or any agency thereof. The views and opinions of authors expressed herein do not necessarily state or reflect those of the United States Government or any agency thereof. 


\title{
MS\&T
}

Materials Science and Technology

Keywords: Corrosion, Structural Integrity, Transfer Lines

Retention - Permanent

\section{A Structural Integrity Assessment of the Tank Farm Waste Transfer System}

\author{
by
}

\author{
B. J. Wiersma
}

SRNL SAVANNAH RIVER NATIONAL LABORATORY, AIKEN, SC 29808 Westinghouse Savannah River Company

Prepared for the U. S. Department of Energy under Contract DE-AC09-96SR18500 


\begin{tabular}{l}
\hline Date: \\
\hline B. J. Wiersma, AUTHOR \\
Materials Performance \& Corrosion Technology Group \\
MATERIALS SCIENCE AND TECHNOLOGY \\
\\
G. B. Rawls, TECHNICAL REVIEWER \\
Materials Applications \& Process Technology Group \\
MATERIALS SCIENCE AND TECHNOLOGY \\
Date: \\
\hline C. F. Jenkins, TECHNICAL REVIEWER
\end{tabular}

NDE and Materials Reliability Group MATERIALS SCIENCE AND TECHNOLOGY

G. T. Chandler, MANAGER

Date:

Materials Performance and Corrosion Technology Group MATERIALS SCIENCE AND TECHNOLOGY

N. C. Iyer, MANAGER

Date:

MATERIALS SCIENCE AND TECHNOLOGY

$\overline{\text { G. D. Thaxton, MANAGER }}$

Date:

Structural Integrity

LIQUID WASTE PROCESS ENGINEERING

E. J. Freed, MANAGER

Date:

Structural Integrity

LIQUID WASTE PROCESS ENGINEERING

D. B. Little

Date:

LIQUID WASTE DISPOSITION PROJECTS 
Table of Contents

1.0 Executive Summary $\quad 1$

2.0 Background $\quad 2$

3.0 Design and Specifications for Radioactive Waste Transfer Lines 3

3.1 Radioactive Waste Transfer Line Design 3

3.1.1 Type I Transfer Lines 3

3.1.2 Type II and IIA Transfer Lines 4

3.1.3 Type III Transfer Lines 5

3.2 Historical Background on Specifications 6

4.0 Degradation Mechanisms 15

4.1 Stainless Steel Core Pipe $\quad 15$

$\begin{array}{lll}\text { 4.1.1 General Corrosion } & 15\end{array}$

$\begin{array}{lll}\text { 4.1.2 } & \text { Pitting } & 18\end{array}$

4.1.3 Stress Corrosion Cracking $\quad 20$

4.1.4 Microbiologically Induced Corrosion 25

4.1.5 Erosion/Erosion Corrosion $\quad 31$

4.1.6 Thermal Fatigue $\quad 35$

4.2 Carbon Steel Jacket Pipe 35

5.0 Monitoring and Inspection of Transfer Lines 40

5.1 Monitoring of Transfer Lines for Through-wall Penetrations 40

5.2 Inspection of Transfer Lines 41

5.2.1 Jackets Associated with FDB-2 42

5.2.2 Radioactive Waste Transfer Lines Associated with Tanks 1 through 844

5.2.3 Jacket for Transfer Line \# 1663 (near Tank 50) 47

5.2.4 Tank 28 Radioactive Waste Transfer Line Jackets 49

6.0 Life Estimation Calculations and Fitness-For-Service Evaluation 52

6.1 Life Estimation Calculations for Stainless Steel Core Pipe 52

6.1.1 General Corrosion $\quad 52$

6.1.2 Erosion/Corrosion $\quad 54$

6.2 Life Estimation Calculations for Carbon Steel Jacket 57

$\begin{array}{ll}\text { 6.2.1 General Corrosion } & 58\end{array}$

$\begin{array}{ll}\text { 6.2.2 Pitting Corrosion } & 58\end{array}$

6.3 Fitness-For-Service for Carbon Steel Jacket $\quad 60$

$\begin{array}{lll}7.0 & \text { Conclusions } & 63\end{array}$

$\begin{array}{lll}\text { 8.0 Acknowledgements } & 64\end{array}$

$\begin{array}{lll}9.0 & \text { References } & 64\end{array}$

Appendix A: Summary of DOE Findings and WSRC Responses i

Appendix B: Calculation Methodology for Determining the Minimum vi

Required Wall Thickness

Appendix C: Calculation of Life Expectancy for Stainless Steel Core Pipe viii

Considering Erosion Due to Sludge Slurry or DWPF Recycle Waste 
List of Tables

Page

Table 1. Nominal Dimensions of Core and Jacket Piping Utilized for Type II and IIA Transfer Lines

Table 2. $\quad$ Review of Specifications for the Tank Farm Transfer Line System Piping

Table 3. $\quad$ Piping Code from Specification 3018

Table 4. $\quad$ Piping Code from Specification $4482 \quad 12$

Table 5. $\quad$ Piping code from Engineering Guide 15060-G 14

Table 6. Molar Anion Concentrations for Simulated Waste Solutions $\quad 17$

Table 7. General Corrosion Rates for 304L Stainless Steel Exposed to Simulated Waste Environments

Table 8. $\quad$ Composition of Simulated Evaporator Solution 18

Table 9. $\quad$ Summary of Thermal Fatigue Analysis for Transfer Lines 36

Table 10. $\quad$ Soil Corrosivity vs. Resistivity 38

Table 11. $\quad$ Wall thickness measurements for Line \#106 (near FDB-2) 43

Table 12. Wall Thickness Measurements on Waste Transfer Line Piping Associated with Tanks 1 through 8

Table 13. Life Expectancy of Stainless Steel Core Pipe Considering Erosion Due to Sludge Slurry and DWPF Recycle Wastes

Table 14. $\quad$ Pit-couple Data from Line \#1663 (near Tank 50) 
List of Figures

Page

Figure 1. Type I Transfer Lines that Travel between Tanks 1 to 8 in F-area 3

Figure 2. Cut-away Drawing of a Type II Transfer Line $\quad 4$

Figure 3. Cut-away Drawing of a Type III Transfer Line 5

Figure 4. Straight Section of Pipe Exhibiting General Corrosion of Carbon Steel $\quad 15$

Figure 5. Polarization curve diagram illustrating the corrosion behavior of a passive material such as stainless steel

Figure 6. Polarization curve showing the corrosion behavior of 304L stainless steel in Solution \#1 at $60^{\circ} \mathrm{C} \quad 17$

Figure 7. $\quad$ Pitting Corrosion on Carbon Steel 19

Figure 8. Cyclic polarization curve that demonstrates pitting corrosion behavior. $\quad 20$

Figure 9. $\quad$ F-Area CTS Pit 23

Figure 10. Section of core pipe from clean-out-port \#3 24

Figure 11. Microbiologically Induced Corrosion on a Pipe 25

Figure 12. Schematic of pit extension by corrosion in the working direction of the material.

Figure 13. Evidence of MIC on the exterior of the cooling water pipe in the DWPF.

Figure 14. Dry tubercle and ring stains on pipe weld associated with MIC 28

Figure 15. Macroview of pipe wall section at weld that shows evidence of MIC.

Figure 16. Preferential corrosion of weld filler material in the vicinity of the MIC attack.

Figure 17. Leaks were located near circumferential welds. 30

Figure 18. Cross-section of the pipe wall showing sub-surface attack. 30

Figure 19. Erosion/Erosion Corrosion on a Pipe 32

Figure 20. Fatigue crack of 501 Transfer Line (near 1-H Evaporator) 37

Figure 21. $\quad$ Sketch of Transfer Line Leak Detection System 41

Figure 22. Diagram showing the location of leak site and area of UT data collection on Line \#106 (near FDB-2).

Figure 23. View of FDB-2, Line \#108 $\quad 44$

Figure 24. Carbon steel elbow from core pipe between Tanks 1 and $7 \quad 46$

Figure 25. Stainless steel elbow from core pipe between Tanks 6 and $7 \quad 47$

Figure 26. View of Line \#1663 (near Tank 50) 48

Figure 27. Thickness Profile of Line \#1663 (near Tank 50) 49

Figure 28. $\quad$ UT Data for Line \#1211 Jacket (near Tank 28) 50

Figure 29. $\quad$ UT Data for Line \# 1218 Jacket (near Tank 28) 51

Figure 30. UT data for Line \# 1216 jacket (near Tank 28) 51

Figure 31. $\quad$ UT data for Line \#1218 jacket (near Tank 28) 52 


\section{A Structural Integrity Evaluation of the Tank Farm Waste Transfer System}

\subsection{Executive Summary}

Radioactive supernate, salt, and/or sludge wastes (i.e., high level wastes) are confined in 49 underground storage tanks at the Savannah River Site (SRS). The waste is transported between tanks within and between the $\mathrm{F}$ and $\mathrm{H}$ area tank farms and other facilities on site via underground and a limited number of aboveground transfer lines. The Department of Energy - Savannah River Operations Office (DOE-SR) performed a comprehensive assessment of the structural integrity program for the Tank Farm waste transfer system at the SRS. This document addresses the following issues raised during the DOE assessment (see Appendix 1 for specifics on the issues raised by the DOE assessment).

- Inspections of failed or replaced transfer lines indicated that the wall thickness of some core and jacket piping is less than nominal.

- No corrosion allowance is utilized in the transfer line structural qualification calculations. No basis for neglecting corrosion was provided in the calculations.

- Wall loss due to erosion is not addressed in the transfer line structural qualification calculations.

- No basis is provided for neglecting intergranular stress corrosion cracking in the transfer line structural qualification calculations.

The common theme in most of these issues is the need to assess the potential for occurrence of material degradation of the transfer line piping. The approach used to resolve these issues involved:

- Review the design and specifications utilized to construct and fabricate the piping system;

- Review degradation mechanisms for stainless steel and carbon steel and determine their relevance to the transfer line piping;

- Review the transfer piping inspection data;

- Life estimation calculations for the transfer lines;

- A Fitness-For-Service evaluation for one of the transfer line jackets.

The evaluation concluded that the transfer line system piping has performed well for over fifty years. Although there have been instances of failures of the stainless steel core pipe during off-normal service, no significant degradation is anticipated during normal operations for the planned service life. General corrosion of stainless steel in high level waste environments was shown to be insignificant (i.e., little or no wall loss is expected for a time on the order of 180 years or more). Erosion is also not expected to limit the life of the pipes due to the low usage of the transfer lines and low fluid velocity during transfers. Quality controls on the material (e.g., corrosion evaluation testing) and procedures/specifications that limit contact with chloride bearing materials or liquids minimize the potential for the occurrence of stress corrosion cracking of the core pipe. 
General corrosion of the carbon steel jacket is not expected to be significant for a reasonable intended service life (e.g., on the order of 170 years). However, the carbon steel jackets are expected to continue to fail in local areas due to pitting corrosion. Life prediction estimates project that a significant increase in the number of jacket failures (i.e., through-wall penetrations) may occur after an additional 30 to 60 years of service life (i.e., between 2035 and 2065). A Fitness-For-Service evaluation was performed for a recently inspected jacket that showed evidence of pitting within a locally thinned area. The evaluation concluded that the line is still able to perform its intended function and can remain in service.

\subsection{Background}

Radioactive supernate, salt, and/or sludge wastes (i.e., high level wastes) are confined in 49 underground storage tanks at the SRS. The waste is transported between tanks within and between the $\mathrm{F}$ and $\mathrm{H}$ area tank farms and other facilities on site via underground and a limited number of aboveground transfer lines. In 1995, the WSRC issued a report that concluded that the waste tanks and the transfer piping systems were structurally sound and maintained a high degree of confinement of the waste under design basis conditions [1]. The report included critical reviews of the potential degradation mechanisms and the design basis load cases for these structures and systems and a summary of the in-service inspection and monitoring program.

Department of Energy Order 435.1, Radioactive Waste Management [2], issued in late 1999, requires that each Hazard Category 2 facility (such as the SRS Tank Farms) perform hazard and accident analyses to derive appropriate safety class and safety significant controls for these structures and systems and identify the necessary periodic tests and inspections such that these structures and systems can continue to perform their required safety function(s). Additionally, DOE Order 433.1, Maintenance Management Program for DOE Nuclear Facilities [3], Section 4 (2), in part, required periodic inspection of SSCs to determine whether degradation or technical obsolescence threatens performance and/or safety. In 2002, the Department of Energy - Savannah River Operations Office (DOE-SR) performed a comprehensive assessment (CST-02-02-002) [4] of WSRC implementation of the aforementioned Structural Integrity (SI) Program [1]. The assessment focused on the performance of the HLW waste storage tanks. A followup assessment for HLW transfer lines was performed in 2005 [5]. The assessment consisted of a review of 8 structural calculations of the 17 most commonly used HLW transfer lines.

This document responds to the issues raised by this assessment. The approach used to resolve these issues involved:

a) Review the design and specifications utilized to construct and fabricate the piping system;

b) Review degradation mechanisms for stainless steel and carbon steel and determine their relevance to the transfer line piping; 
c) Review the transfer piping inspection data;

d) Life estimation calculations for the transfer lines;

e) A Fitness-For-Service evaluation for one of the transfer line jackets.

\subsection{Design and Specifications for Radioactive Waste Transfer Lines}

\subsection{Radioactive Waste Transfer Line Design}

\subsubsection{Type I Transfer Lines}

The Type I transfer lines are the oldest transfer lines on site (circa 1953) [6]. These lines were utilized to transfer waste into and out of the Type I and II waste tanks. Although they represent nearly $20 \%$ of the transfer lines, most of these lines are currently inactive. The primary or core line is constructed of 304 stainless steel. The pipe size is 3 inch schedule 40 ( 0.216 inch wall thickness). The secondary containment for the Type I lines is a concrete encasement. The encasements consist of reinforced concrete troughs which have reinforced concrete slab covers. The encasement is generally several hundred feet long and tapers to smaller dimensions as the number of transfer lines within the encasement decreases. The encasements are supported by columns spaced approximately 25 feet apart and are buried beneath 10-18 feet of backfilled soil.

Figure 1 shows a view of the Type I transfer lines in the concrete encasement that is located between Tanks 1 and 8 in F-area [7]. The transfer lines rest on a concrete beam approximately 1 foot above the bottom of the trough. The joint between the cover and the trough is sealed by bitumastic caulking and asphalt paint. The outside of the concrete trough is protected with a glass fiber fabric waterproofing membrane topped by a one inch layer of cement plaster. The sizes of the trough and the covers depend on the number of pipes that are encased. For example, with 16 transfer lines the cover slabs are 9 feet 2 inches by 9 feet 3.5 inches by 12 inches thick. The smallest cover slab, which encases 4 transfer lines, is 3 feet 2 inches square and 12 inches thick. The sizes of the reinforcing steel in the cover slabs are from $1 / 2$ inch to $7 / 8$ inch in diameter inclusive. The reinforcing steel is covered by a minimum of one inch of concrete.

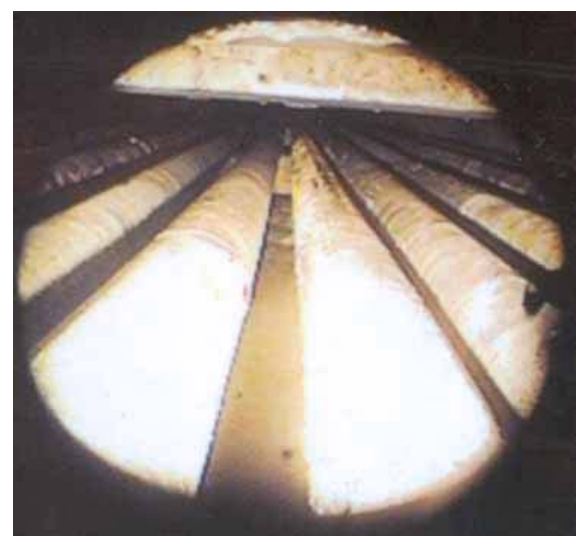

Figure 1. View of Type I Transfer Lines in Concrete Encasement between Tanks 1 to 8 in F-area 


\subsubsection{Type II and IIA Transfer Lines}

The most common type of transfer line is the Type II transfer line (approximately $77 \%$ of the lines). This type of line has been in service since 1960. Figure 2 shows a cut-away drawing of the Type II transfer line. The core pipe is typically made of either 304L stainless steel (Type II) or carbon steel (Type IIA). Table 1 shows the sizes of the core and jacket pipes used for the transfer lines. The sizes of the core piping range between 13 inches in diameter [8]. From available documents [9, 10] schedule 40 piping was utilized; therefore the nominal wall thickness of the piping ranges between $0.133-0.216$ inches.

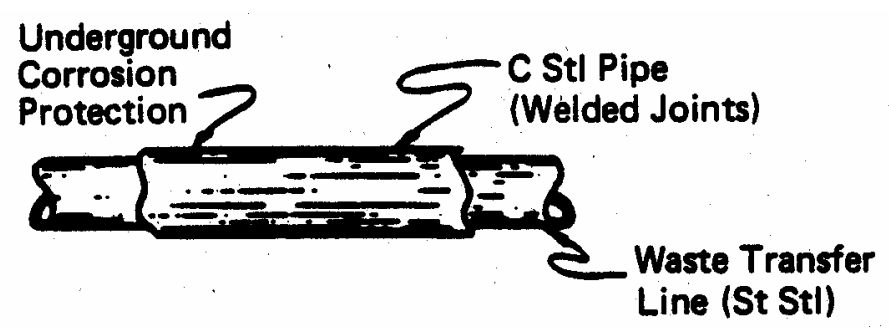

Figure 2. Cut-away drawing of a Type II transfer line. The Type IIA transfer line has the same configuration; except the core pipe is made of carbon steel.

The jacket pipe is constructed of carbon steel. The size of the jacket piping will vary depending on the number of transfer lines that are contained (usually between 1 and 3 ). From available documents many different pipe schedules were utilized for the jackets. For example, schedule 40 piping was utilized for 3 and 4 inch diameter piping [10-12], 6 inch [9], 8 inch [13], and 10 inch diameter piping [13]. In one case a non-standard wall thickness was utilized. The 4 inch jackets near FDB-2 in most cases have a wall thickness of 0.156 " [14].

The outside of the jacket piping is usually protected by one of several coating methods: a fusion bonded powder coating system, a coal-tar system, a polyethylene coating, a polyethylene tape, or a bitumastic coating $[15,16]$. The first four coatings were utilized on the older pipes (circa 1950-1970), while the last coating has been utilized for the more recently constructed or repaired transfer lines. The thickness of the outer protection for the jacket depends on the type of coating utilized.

There are also examples where the jacket piping is contained in an underground concrete trench [17]. In these cases the lines are associated with Type IV tanks that were constructed in H-area during the early 1960's. 
WSRC-TR-2005-00532

March, 2006

Page 5 of 69

Table 1. Nominal Dimensions of Core and Jacket Piping Utilized for Type II and IIA Transfer Lines

\begin{tabular}{|c|c|c|c|}
\hline Description & $\begin{array}{l}\text { Nominal } \\
\text { Thickness } \\
\text { (in.) }\end{array}$ & $\begin{array}{l}\text { Minimum } \\
\text { Thickness* } \\
\text { (in.) }\end{array}$ & $\begin{array}{c}\text { Actual } \\
\text { Measurement } \\
\text { (in.) }\end{array}$ \\
\hline 1" diameter Sch. 40 Stainless Steel Core & 0.133 & 0.116 & $\mathrm{~N} / \mathrm{A}$ \\
\hline 1.5" diameter Sch. 40 Stainless Steel Core & 0.145 & 0.127 & $\mathrm{~N} / \mathrm{A}$ \\
\hline 2" diameter Sch. 40 Stainless Steel Core & 0.154 & 0.135 & $\mathrm{~N} / \mathrm{A}$ \\
\hline $\begin{array}{l}\text { 3" diameter Sch. } 40 \text { Stainless Steel Core } \\
\text { (3 lines were measured) }\end{array}$ & 0.216 & 0.189 & $0.19-0.20$ \\
\hline $\begin{array}{l}\text { 3" diameter Sch. } 40 \text { Carbon Steel Core } \\
\text { (5 lines were measured) }\end{array}$ & 0.216 & 0.189 & $0.19-0.24$ \\
\hline 3" diameter Sch. 40 Carbon Steel Jacket & 0.216 & 0.189 & $\mathrm{~N} / \mathrm{A}$ \\
\hline 4" diameter Sch. 40 Carbon Steel Jacket & 0.237 & 0.207 & 0.21 \\
\hline 4" diameter Carbon Steel Jacket & $0.156 * *$ & 0.137 & 0.156 \\
\hline 6" diameter Carbon Steel Jacket & $0.188 * * *$ & 0.164 & 0.188 \\
\hline 8" diameter Sch. 20 Carbon Steel Jacket & 0.25 & 0.219 & $\mathrm{~N} / \mathrm{A}$ \\
\hline 10" diameter Sch. 20 Carbon Steel Jacket & 0.25 & 0.219 & $\mathrm{~N} / \mathrm{A}$ \\
\hline
\end{tabular}

* - Minimum thickness is 0.875 x nominal thickness [107]

** - Drawing W235672 specifies this nominal thickness.

*** - Drawing W702752 specifies this nominal thickness.

\subsubsection{Type III Transfer Lines}

Type III transfer lines were constructed in the late 1950's and are utilized to transfer low level waste. These lines represent approximately $3 \%$ of the total number of transfer lines. They consist of a stainless steel core surrounded by a cement-asbestos jacket also referred to as transite. A cut-away drawing of the pipe is shown in Figure 3 [18]. The core pipe is 3 inch schedule 40 (0.216 inch wall thickness), while the diameter of the jacket ranges from 6-12 inches and is pressure tested to 100 psig (i.e., the wall thickness of the cement ranges between $0.42-0.64$ inches) $[19,20]$. These lines are no longer utilized on site [113].

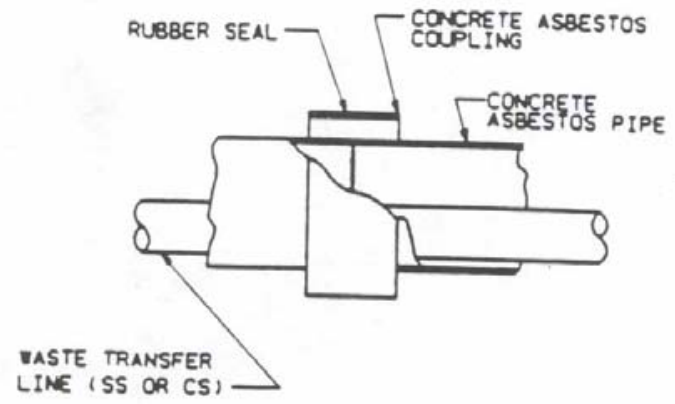

Figure 3. Cut-away Drawing of a Type III Transfer Line 


\section{Page 6 of 69}

\subsection{Historical Background on Specifications}

DuPont Specification 3018 is the original piping specification compiled when the plant was built in 1951 [21]. It was originally issued in May 1951 and was discontinued on November 1, 1961. It became apparent that Specification 3018 had become obsolete and extensive revision was necessary. But to avoid radical changes to Specification 3018 that would destroy the as-built records of the original piping on the site, DuPont Specification 4482 was created to contain all updated P-codes and additions made after November 1 , 1961 [22]. Most of the piping associated with the Type III/IIIA tanks was built according to this Specification 4482. Specification 4482 was in effect until 1990 when it was superseded by Westinghouse Engineering Requirements [23]. Currently this document is referred to as Engineering Guide 15060-G. Transfer lines that were either built or modified since 1990 were fabricated and erected per Engineering Guide 15060-G [23].

Table 2 shows items from each specification which would have a bearing on the initial wall thickness, inspections, or actions that would have mitigated concerns with corrosion. Tables 3 through 5 highlight specific items from each of the P-code requirements for the given Specification that also impact corrosion concerns. The tables indicate that similar considerations went into the design, fabrication and installation of all the transfer lines. The largest exception may be that the latter two specification/standard (4482 and 15060) had specific requirements to (1) limit contact between stainless steel and chloride bearing materials [24, 25], (2) require corrosion evaluation [26-28], and (3) control moisture and residual water levels in the piping during construction and following hydrotesting [29, 30].

A specification for limiting contact between chloride bearing materials (e.g., wrapping tape, markers, gaskets, thermal insulation, etc.) and stainless steels has been in effect since 1971 [24]. Thus the requirement limiting the chloride concentration would not have applied to piping placed earlier under Specification 3018 and 4482 up until 1971. It should be noted that this specification does not place limits on the concentration of chloride in a liquid in contact with stainless steel, but rather places a limit on the amount of chloride in a solid material or ink in contact with the stainless steel. The chloride concentration limit for these materials is $250 \mathrm{ppm}$. Materials with chloride concentrations greater than $250 \mathrm{ppm}$ may be utilized, however, if the temperature of the environment is less than $40{ }^{\circ} \mathrm{C}$. As will be discussed later in the report, there were cases prior to 1971 where chlorides from materials in contact with stainless steel did cause stress corrosion cracking.

Corrosion evaluation is a series of screening tests that determines whether a material is susceptible to intergranular attack. Historical documents indicate that the corrosion evaluation specification was first issued in 1965 [26]. Prior to that time, Specifications 3018 and 4482 required the stainless steel to be in the solution annealed condition [31] in order to minimize the potential for intergranular attack (see discussion in Section 4.1.3 for further discussion of solution annealing). Therefore, if the pipe was welded into place, a heat treatment to return the pipe to the solution annealed condition was required 
before the pipe was placed in service. Thus, all three specifications have requirements that would minimize intergranular attack.

Corrosion problems can also result when residual water is allowed to remain in contact with the piping during construction, hydrotesting, or standby conditions. The most likely types of corrosion in these situations are chloride stress corrosion cracking and microbiologically induced corrosion. These mechanisms will be discussed in detail in the later section on degradation mechanisms. Historical documents indicate that guidelines to minimize the potential for these corrosion problems were instituted in 1977 [29, 30]. One of the preventative measures is to utilize low chloride water $(<50 \mathrm{ppm})$ for hydrotesting.

One specific change relevant to wall thickness is significant with respect to this evaluation. In 1986, a review was conducted to determine if Schedule 10 piping could be utilized rather than Schedule 40 for stainless steel core piping, which had been utilized since the beginning of the plant [32]. The following reasons were given for allowing the change to Schedule 10.

a) The greater flexibility of Schedule 10 over Schedule 40 allows for more latitude in the design of an installation with lower anchor loads and pipe stresses. This reduces the potential of pipe failures during process upsets such as steam blowouts during jet transfers.

b) Defects in Schedule 10 piping are more easily detected by radiographic examination than those in Schedule 40 pipe because of the thinner wall.

a) Erosion is not a significant consideration since tests performed on waste sludge have shown that it is soft and non-abrasive. Therefore, the extra wall thickness provided by Schedule 40 vs. Schedule 10 was judged not to be required.

Revision 106 of Specification 4482 indicates that this recommendation was accepted and applied to piping installed after October, 1986. 
Page 8 of 69

Table 2. Review of Specifications for the Tank Farm Transfer Line System Piping.

\begin{tabular}{|c|c|c|c|}
\hline Item & 3018 & 4482 & 15060 \\
\hline Required Piping Codes & A.S.A B-31.1 for Pressure Piping & $\begin{array}{l}\text { ASME B-31.3 for Chemical Plant and } \\
\text { Petroleum Refinery Piping }\end{array}$ & $\begin{array}{l}\text { ASME B-31.3 for Chemical Plant and } \\
\text { Petroleum Refinery Piping }\end{array}$ \\
\hline P-Codes Applicable to Core Piping & P39.020 & $\begin{array}{l}\text { P48 (underground piping) } \\
\text { P53 (aboveground piping such as } \\
\text { evaporator overhead vents) }\end{array}$ & $\begin{array}{l}\text { PS200C } \\
\text { PS200A }\end{array}$ \\
\hline P-Codes Applicable to Jackets & $\begin{array}{l}\text { In most cases there was not a jacket } \\
\text { surrounding the transfer line. The } \\
\text { lines were encased in a concrete vault. } \\
\text { In some cases where a carbon steel } \\
\text { jacket is utilized, the drawing contains } \\
\text { information on the dimensions of the } \\
\text { pipe. In one case, the piping } \\
\text { specification was API 5L. }\end{array}$ & $\begin{array}{l}\text { P51 } \\
\text { P51A } \\
\text { P51B }\end{array}$ & $\begin{array}{l}\text { PS103C } \\
\text { PS101C }\end{array}$ \\
\hline Allowable Pipe Sizes & $\begin{array}{l}\text { All underground piping must be } \\
\text { greater than } 1 \text { inch diameter. The } \\
\text { typical core pipe is } 3 \text { " diameter. }\end{array}$ & $\begin{array}{l}\text { All underground piping must be } \\
\text { greater than } 1 \text { inch diameter. The } \\
\text { typical core pipe is } 3 \text { " diameter. } \\
\text { Typical jacket pipe is } 4 \text { to } 10 \text { " } \\
\text { depending on the number of pipes } \\
\text { within the jacket. }\end{array}$ & $\begin{array}{l}\text { All underground piping must be } \\
\text { greater than } 1 \text { inch diameter. The } \\
\text { typical core pipe is } 3 \text { " diameter. } \\
\text { Typical jacket pipe is } 4 \text { to } 10 \text { " } \\
\text { depending on the number of pipes in } \\
\text { jacket. }\end{array}$ \\
\hline
\end{tabular}


WSRC-TR-2005-00532

March, 2006

Page 9 of 69

Table 2. (cont.)

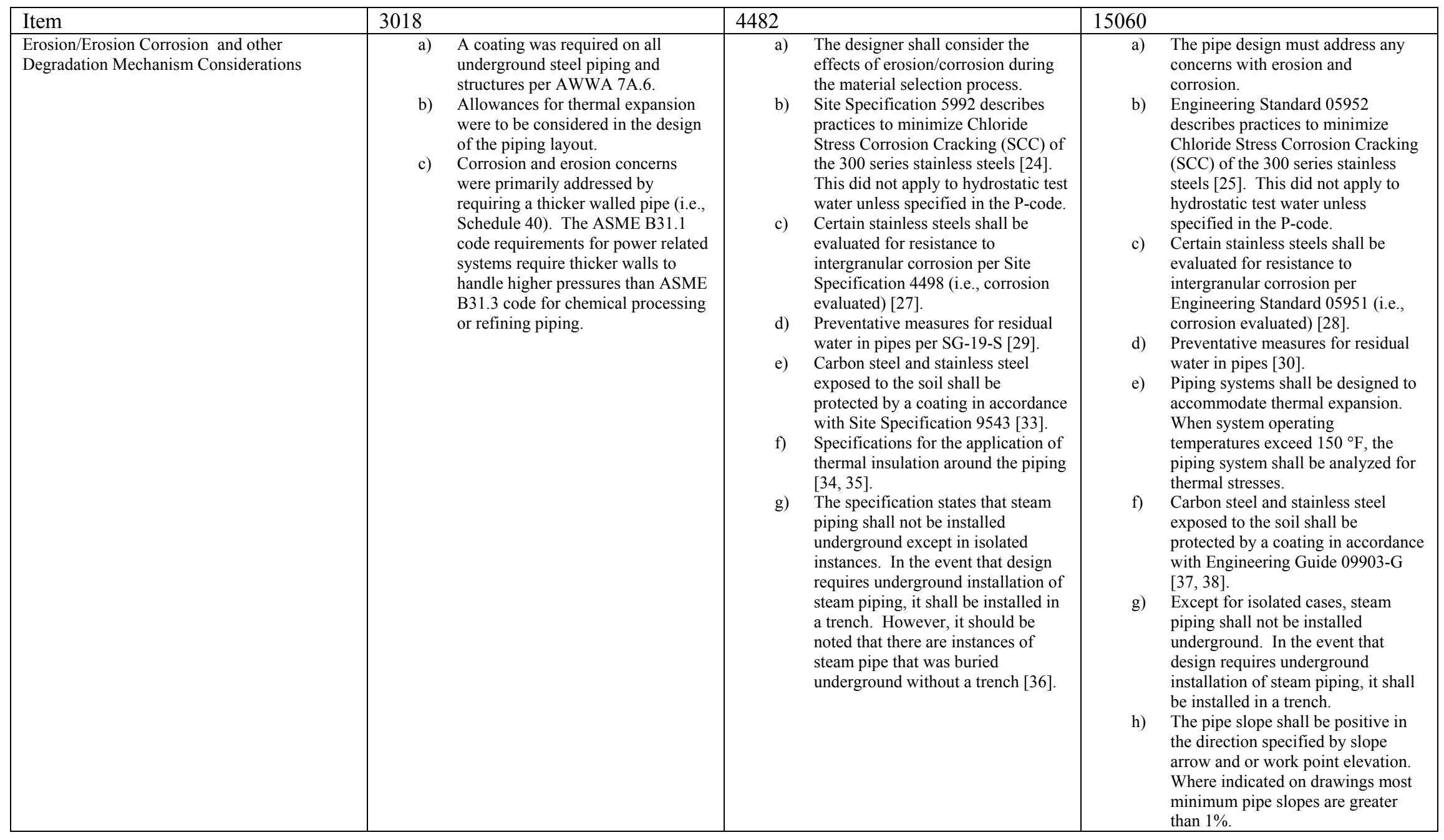


Table 2. (cont.)

\begin{tabular}{|c|c|c|c|c|c|c|}
\hline Item & 3018 & & 4482 & & 15060 & \\
\hline Pipe Bending & $\begin{array}{l}\text { d) } \\
\text { e) } \\
\text { f) } \\
\text { g) }\end{array}$ & $\begin{array}{l}\text { Cold forming of bends was } \\
\text { preferred. } \\
\text { The center-line radius for a } 3 \\
\text { inch pipe was between } 15 \text { to } \\
25.75 \text { inches for a cold bend. } \\
\text { Stainless steel bends were } \\
\text { hot formed only when } \\
\text { necessary. } \\
\text { If the bend was hot formed, } \\
\text { the stainless steel was } \\
\text { required to be subsequently } \\
\text { heat treated to a temperature } \\
\text { between } 1950 \text { and } 2050{ }^{\circ} \mathrm{C} \\
\text { for } 30 \text { minutes and then } \\
\text { immediately quenched in } \\
\text { water. }\end{array}$ & $\begin{array}{l}\text { i) } \\
\text { j) } \\
\text { k) } \\
\text { 1) }\end{array}$ & $\begin{array}{l}\text { Hot bending of any piping } \\
\text { shall not be done without } \\
\text { prior engineering approval of } \\
\text { procedures used. } \\
\text { Hot bending austenitic } \\
\text { stainless steels shall be } \\
\text { followed by a full solution } \\
\text { anneal (See heat treatment } \\
\text { for Specification } 3018 \text { ). } \\
\text { Thinning of the wall } \\
\text { thickness at the elbow was } \\
\text { not to exceed } 10 \% \text { for a bend } \\
\text { radius of } 5 \text { pipe diameters or } \\
\text { larger or } 18 \% \text { for a bend } \\
\text { radius of } 3 \text { pipe diameters or } \\
\text { larger. } \\
\text { Depth of wrinkles on the } \\
\text { inside of the bend shall not } \\
\text { exceed } 1.5 \% \text { of the nominal } \\
\text { pipe size. } \\
\text { The longitudinal weld shall } \\
\text { not be located within } 30 \\
\text { degrees of the plane of bend } \\
\text { measured axially from the } \\
\text { pipe centerline. }\end{array}$ & $\begin{array}{l}\text { i) } \\
\text { j) } \\
\text { k) } \\
\text { 1) } \\
\\
\text { m) }\end{array}$ & $\begin{array}{l}\text { Hot bending of any piping } \\
\text { shall not be done without } \\
\text { prior engineering approval of } \\
\text { procedures used. } \\
\text { Hot bending austenitic } \\
\text { stainless steels shall be } \\
\text { followed by a full solution } \\
\text { anneal (See heat treatment } \\
\text { for Specification } 3018 \text { ). } \\
\text { The longitudinal weld shall } \\
\text { not be located within } 30 \\
\text { degrees of the plane of bend } \\
\text { measured axially from the } \\
\text { pipe centerline. } \\
\text { Thinning of the wall } \\
\text { thickness at the elbow was } \\
\text { not to exceed } 10 \% \text { for a bend } \\
\text { radius of } 5 \text { pipe diameters or } \\
\text { larger or } 21 \% \text { for a bend } \\
\text { radius of } 3 \text { pipe diameters or } \\
\text { larger. } \\
\text { Depth of wrinkles on the } \\
\text { inside of the bend shall not } \\
\text { exceed } 1.5 \% \text { of the nominal } \\
\text { pipe size. }\end{array}$ \\
\hline
\end{tabular}


Table 3. Piping Code from Specification 3018

\begin{tabular}{|c|c|}
\hline Item & P39.020 for Stainless Steel Core Piping \\
\hline Material & 304 Stainless Steel; Dimensions are to conform to ASA standard B36.19. \\
\hline Pressure Limit & 160 to 400 psig \\
\hline Temperature Limit & $200^{\circ} \mathrm{F}$ \\
\hline $\begin{array}{l}\text { Welding Codes and } \\
\text { Procedures }\end{array}$ & $\begin{array}{l}1949 \text { ASME Boiler Code Section IX, Paragraph U68; Inert-gas-shielded-arc- } \\
\text { welding }\end{array}$ \\
\hline Bending & $\begin{array}{l}\text { a) Pipe bends shall have no ripples greater than } 0.125 \text { " from the normal surface. } \\
\text { b) The wall thickness after bending and scale removal is to be no less than } 87 \% \\
\text { of the nominal wall thickness. }\end{array}$ \\
\hline Fit-up & $\begin{array}{l}\text { Special measures for limiting turbulence in the pipe were required. Obstructions in } \\
\text { the pipe were to be no greater than } 1 / 32 \text { " and the weld joints produce an off-set no } \\
\text { greater than } 1 / 32 \text { ". }\end{array}$ \\
\hline Corrosion Allowance & Not Specified \\
\hline Leak Testing & Freon at a test pressure of $55 \mathrm{psig}$; Hydrostatic at a test pressure of $750 \mathrm{psig}$. \\
\hline Stress Relief & $\begin{array}{l}\text { Heat treatment procedures for welded stainless steel pipes are included in the } \\
\text { specification. Pipe material is required to be in the solution annealed condition [29]. }\end{array}$ \\
\hline Weld Inspection & $\begin{array}{l}\text { Complete x-ray examination of all welds on process piping to be embedded or } \\
\text { encased. }\end{array}$ \\
\hline
\end{tabular}


Table 4. Piping Code from Specification 4482

\begin{tabular}{|c|c|c|c|c|c|c|c|}
\hline & \multicolumn{2}{|c|}{ Core Pipe } & \multicolumn{5}{|c|}{ Jacket Pipe } \\
\hline Item & $\mathrm{P} 48$ & P53 & P51 & P51A & & P51B & \\
\hline Material & 304L Stainless Steel & 304L Stainless Steel & $\begin{array}{l}\text { A53 or A106 Carbon } \\
\text { Steel }\end{array}$ & $\begin{array}{l}\text { A53 or } \\
\text { Steel }\end{array}$ & A106 Carbon & $\begin{array}{l}\text { A53 or } \\
\text { Steel }\end{array}$ & A106 Carbon \\
\hline Design Pressure (psig) & 150 & 190 & 230 & 230 & & 300 & \\
\hline $\begin{array}{l}\text { Design Temperature } \\
\left({ }^{\circ} \mathrm{F}\right)\end{array}$ & 370 & 370 & 650 & 180 & & 180 & \\
\hline Code & $\begin{array}{l}\text { ASME B31.3 Severe } \\
\text { Cyclic }\end{array}$ & ASME B31.3 Normal & & & & & \\
\hline $\begin{array}{l}\text { Total combined } \\
\text { allowance for corrosion } \\
\text { and erosion }\end{array}$ & 0.05 inches & 0.0 & 0.05 inches & $0.05 \mathrm{inc}$ & hes & $0.05 \mathrm{inc}$ & hes \\
\hline $\begin{array}{l}\text { Specification } 5992 \\
\text { (Maximum Chloride) }\end{array}$ & Required & Required & NA & NA & & NA & \\
\hline $\begin{array}{l}\text { Specification } 4498 \\
\text { (Corrosion Evaluation) }\end{array}$ & Required & Required & NA & NA & & NA & \\
\hline Pipe Schedule & $\begin{array}{l}\text { 1986-Present: 10S } \\
\text { 1951-1986: } 40\end{array}$ & $\begin{array}{l}\text { 1986-Present: 10S } \\
\text { 1951-1986: } 40\end{array}$ & $\begin{array}{l}4 \text { to } 6 \text { inch diameter: } 40 \\
8 \text { to } 12 \text { inch diameter: } \\
20\end{array}$ & $\begin{array}{l}4 \text { to } 6 \text { in } \\
8 \text { to } 12 \text { i } \\
20\end{array}$ & $\begin{array}{l}\text { ch diameter: } 40 \\
\text { nch diameter: }\end{array}$ & $\begin{array}{l}4 \text { to } 6 \text { in } \\
8 \text { to } 12 \\
20\end{array}$ & $\begin{array}{l}\text { ch diameter: } 40 \\
\text { nch diameter: }\end{array}$ \\
\hline Welding Procedure & GTAW & GTAW & GTAW & GTAW & & GTAW & \\
\hline Weld Inspection & 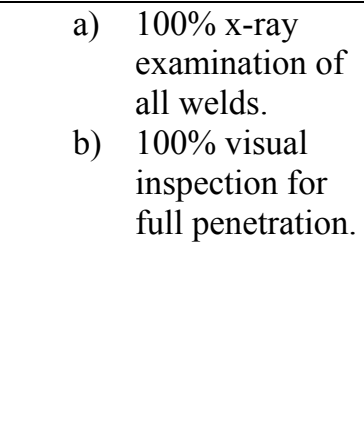 & $\begin{array}{l}100 \% \text { x-ray } \\
\text { examination of all } \\
\text { welds. }\end{array}$ & 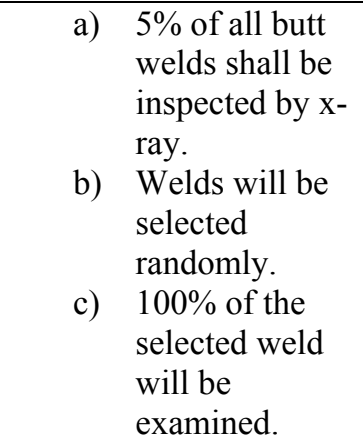 & $\begin{array}{l}\text { a) } \\
\text { b) } \\
\text { c) }\end{array}$ & $\begin{array}{l}5 \% \text { of all butt } \\
\text { welds shall be } \\
\text { inspected by x- } \\
\text { ray. } \\
\text { Welds will be } \\
\text { selected } \\
\text { randomly. } \\
100 \% \text { of the } \\
\text { selected weld } \\
\text { will be } \\
\text { examined. }\end{array}$ & $\begin{array}{l}\text { a) } \\
\text { b) } \\
\text { c) }\end{array}$ & $\begin{array}{l}5 \% \text { of all butt } \\
\text { welds shall be } \\
\text { inspected by x- } \\
\text { ray. } \\
\text { Welds will be } \\
\text { selected } \\
\text { randomly. } \\
100 \% \text { of the } \\
\text { selected weld } \\
\text { will be } \\
\text { examined. }\end{array}$ \\
\hline
\end{tabular}




\section{Page 13 of 69}

Table 4. (cont.)

\begin{tabular}{|c|c|c|c|c|c|c|}
\hline & \multicolumn{3}{|c|}{ Core Pipe } & \multicolumn{3}{|c|}{ Jacket Pipe } \\
\hline Item & $\mathrm{P} 48$ & & P53 & P51 & P51A & P51B \\
\hline Leak Testing & a) & $\begin{array}{l}\text { Freon or gas } \\
\text { bubble test at } 20 \\
\text { psig. } \\
\text { Hydrostatic } \\
\text { testing at the } \\
\text { service pressure. } \\
\text { Chloride level in } \\
\text { water must meet } \\
\text { the requirements } \\
\text { of Specification } \\
4482 \text {. }\end{array}$ & NA & NA & NA & NA \\
\hline Stress Relief & & t Required & Not Required & Not Required & Not Required & Not Required \\
\hline
\end{tabular}

GTAW - Gas Tungsten Arc Welding 
Table 5. Piping code from Engineering Guide 15060-G

\begin{tabular}{|c|c|c|c|c|}
\hline & \multicolumn{2}{|c|}{ Core Pipe } & \multicolumn{2}{|c|}{ Jacket Pipe } \\
\hline Item & PS200C & PS200A & PS103C & PS101C \\
\hline Material & $304 \mathrm{~L}$ & $304 \mathrm{~L}$ & $\begin{array}{l}\text { ASTM A53 or A106 } \\
\text { Carbon Steel }\end{array}$ & $\begin{array}{l}\text { ASTM A53 or A106 } \\
\text { Carbon Steel }\end{array}$ \\
\hline Design Pressure (psig) & 150 & 150 & 300 & 150 \\
\hline Design Temperature $\left({ }^{\circ} \mathrm{F}\right)$ & 370 & 250 & 650 & 180 \\
\hline Code & $\begin{array}{l}\text { ASME B31.3-2002, } \\
\text { Normal }\end{array}$ & $\begin{array}{l}\text { ASME B31.3-2002, } \\
\text { Normal }\end{array}$ & $\begin{array}{l}\text { ASME B31.3-2002, } \\
\text { Normal }\end{array}$ & $\begin{array}{l}\text { ASME B31.3-2002, } \\
\text { Normal }\end{array}$ \\
\hline $\begin{array}{l}\text { Total combined } \\
\text { allowance for corrosion } \\
\text { and erosion }\end{array}$ & 0.05 inches & 0.0 inches & 0.063 & 0.063 inches \\
\hline $\begin{array}{l}\text { SRSES 05950-03-R } \\
\text { (Maximum Chloride) }\end{array}$ & Required & Required & NA & NA \\
\hline $\begin{array}{l}\text { SRSES 05950-01-R } \\
\text { (Corrosion Evaluation) }\end{array}$ & Required & Required & NA & NA \\
\hline Pipe Schedule & $\begin{array}{l}\text { Piping } 3 \text { inches or less: } \\
10 \mathrm{~S} \\
\text { Piping between } 4 \text { and } 6 \\
\text { inches: } 40 \mathrm{~S}\end{array}$ & $10 \mathrm{~S}$ & $\begin{array}{l}4 \text { inch piping: } 40 \\
6 \text { inch piping: } 80 \\
8 \text { inch piping or more: } \\
40\end{array}$ & $\begin{array}{l}\text { Piping between } 4 \text { and } 10 \\
\text { inches: } 40 \\
\text { Piping between } 12 \text { and } \\
16 \text { inches: } 30 \\
\text { Piping } 18 \text { inches or } \\
\text { more: } 20\end{array}$ \\
\hline Welding Procedure & ERW & ERW & ERW or EFW & ERW or EFW \\
\hline Stress Relief & Not required & Not Required & Not Required & Not Required \\
\hline
\end{tabular}

ERW - Electrical Resistance Welding

EFW - Electro-Fusion Welding 


\subsection{Degradation Mechanisms}

\subsection{Stainless Steel Core Pipe}

\subsubsection{General Corrosion}

General corrosion is the term used to describe attack that proceeds in a relatively uniform manner over the entire surface of a metal or alloy (see Figure 4 [39]). The material becomes thinner as it corrodes until its thickness is reduced to the point at which failure occurs due to the stresses on the structure. Stainless steels exhibit general corrosion in strong acids or alkalies at high temperatures (e.g., near the boiling point). While stainless steels are utilized occasionally under these conditions, this is usually the exception rather than the norm. In most cases stainless steel is utilized in an environment with low general corrosion rates. The state in which a stainless steel exhibits a low general corrosion rate is referred to as "passivity". The passive behavior is attributed to an adherent chromium oxide film that forms on the surface.

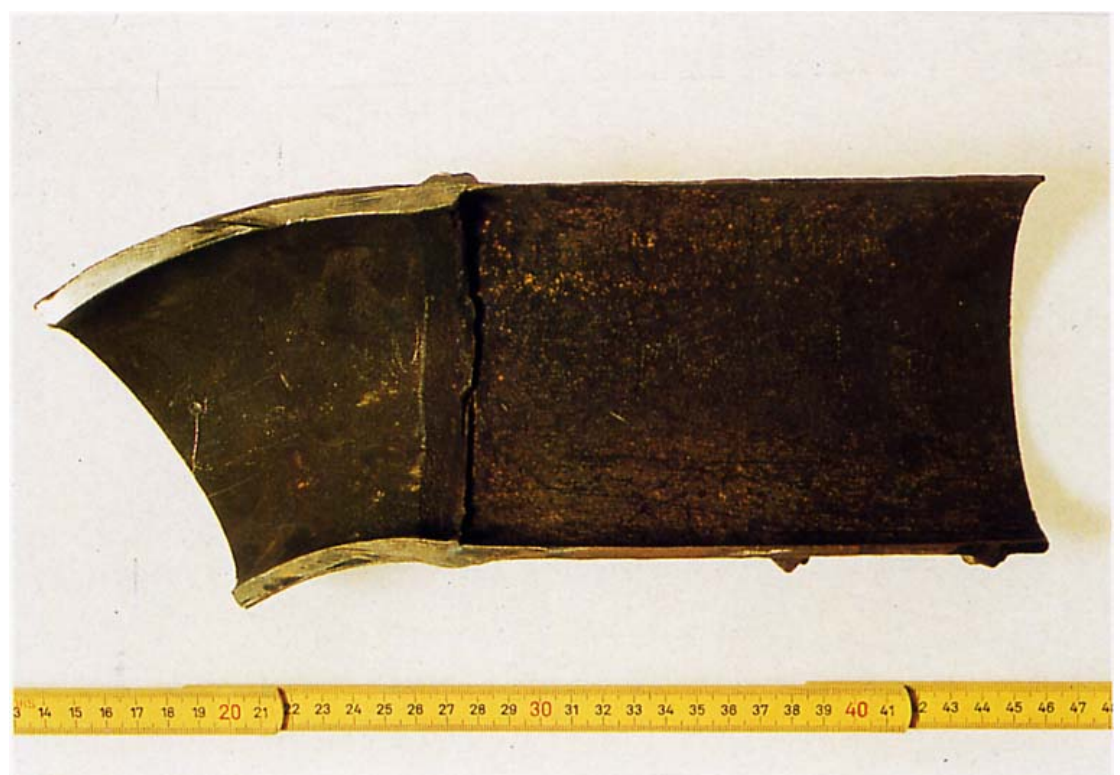

Figure 4. Straight Section of Pipe Exhibiting General Corrosion of Carbon Steel [39]. Note that this is not piping from the SRS waste transfer line system.

A convenient way to understand passivity is to consider a potential-current density diagram or polarization curve (see Figure 5). As the applied potential is increased in the noble or positive direction from the open circuit potential $\left(\mathrm{E}_{\mathrm{corr}}\right)$, the current density also increases, indicating increased corrosion activity. However, at and above a potential referred to as the primary passivation potential $\left(\mathrm{E}_{\mathrm{pp}}\right)$ the current density decreases significantly. This current decrease is referred to as the active-passive transition. Above $\mathrm{E}_{\mathrm{pp}}$, the current density drops to a very low value referred to as the passive current 
density $\left(i_{p}\right)$ and remains at this value over a wide range of potentials. The passive potential range that is shown in the figure defines passivity for a given stainless steelenvironment combination.

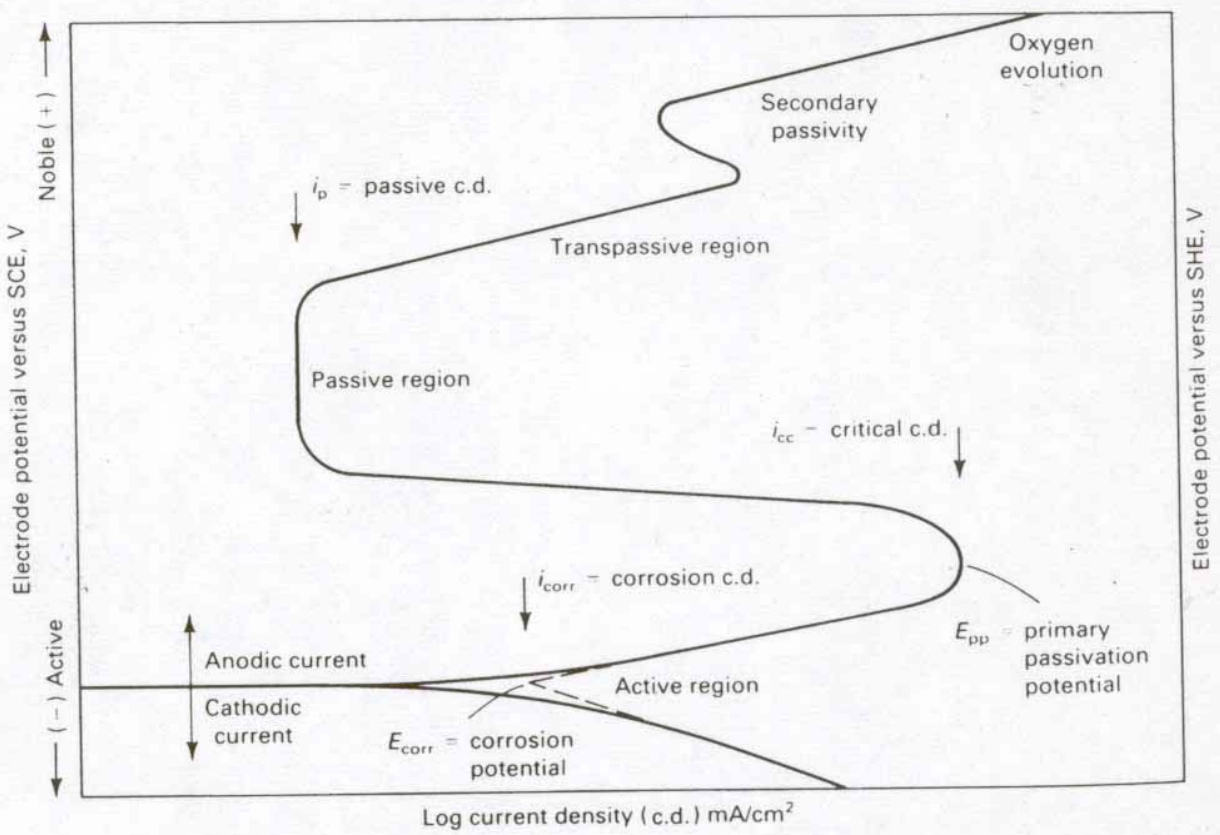

Figure 5. Polarization curve diagram illustrating the corrosion behavior of a passive material such as stainless steel.

Polarization curves were obtained for 304L stainless steel exposed to simulated high level waste environments [40]. The compositions of the simulants are shown in Table 6. The tests were performed at temperatures of 30,45 , and $60{ }^{\circ} \mathrm{C}$. The simulants are representative of unconcentrated supernate and dilute sludge slurries. The polarization behavior was similar for all the simulants. The polarization curve for solution \#1 at 60 ${ }^{\circ} \mathrm{C}$ is shown in Figure 6. The low current density and wide passive potential region indicate that very low general corrosion rates would be expected for stainless steel exposed to waste environments. This behavior is expected as the passive oxide film for 304L stainless is stable in moderate hydroxide and nitrate solutions at moderate temperatures [41].

Coupon tests were also performed in the same simulants [42]. The average general corrosion rates for each of the five solutions are summarized in Table 7 . The general corrosion rate did not vary significantly with temperature between 30 and $60{ }^{\circ} \mathrm{C}$, therefore only a single average corrosion rate was reported. The corrosion rates for the most part are significantly less than $0.1 \mathrm{mpy}$. Solution 4 would provide an upper bound general corrosion rate, $0.078 \mathrm{mpy}$, for stainless steel exposed to these solutions and conditions. 
WSRC-TR-2005-00532

March, 2006

Page 17 of 69

Table 6. Molar Anion Concentrations for Simulated Waste Solutions

\begin{tabular}{|l|c|c|c|c|c|}
\hline $\begin{array}{l}\text { Solution } \\
\text { Number }\end{array}$ & 1 & \multicolumn{1}{l|l}{} & 8 & 11 & 13 \\
\hline $\mathrm{pH}$ & 13.7 & 13.6 & 12.7 & 12.4 & 12.5 \\
\hline $\mathrm{OH}^{-}$ & 2.1 & 1.3 & 0.15 & - & - \\
\hline $\mathrm{CO}_{3}{ }^{=}$ & 0.1 & 0.16 & 0.098 & - & - \\
\hline $\mathrm{NO}_{2}{ }^{-}$ & 1.1 & 0.6 & 0.07 & - & - \\
\hline $\mathrm{NO}_{3}{ }^{-}$ & 1.4 & 2.0 & 0.7 & - & 4.6 \\
\hline $\mathrm{Cl}^{-}$ & 0.022 & 0.022 & 0.0013 & - & - \\
\hline $\mathrm{F}^{-}$ & 0.011 & 0.015 & - & - & 0.039 \\
\hline $\mathrm{SO}_{4}{ }^{=}$ & 0.095 & 0.14 & 0.0079 & - & - \\
\hline $\mathrm{Al}(\mathrm{OH})_{4}{ }^{-}$ & 0.3 & 0.31 & 0.007 & - & 0.26 \\
\hline $\mathrm{C}_{2} \mathrm{O}_{4}{ }^{-}$ & 0.0051 & 0.014 & - & - & - \\
\hline $\mathrm{CrO}_{4}{ }^{-}$ & 0.0021 & 0.0033 & 0.00084 & 0.013 & - \\
\hline $\mathrm{MoO}_{4}{ }^{=}$ & 0.00027 & 0.00043 & - & - & - \\
\hline $\mathrm{SiO}_{3}{ }^{-}$ & 0.0021 & 0.0038 & 0.00058 & - & - \\
\hline $\mathrm{PO}_{4}{ }^{3-}$ & 0.0058 & 0.0085 & 0.014 & 0.22 & - \\
\hline
\end{tabular}

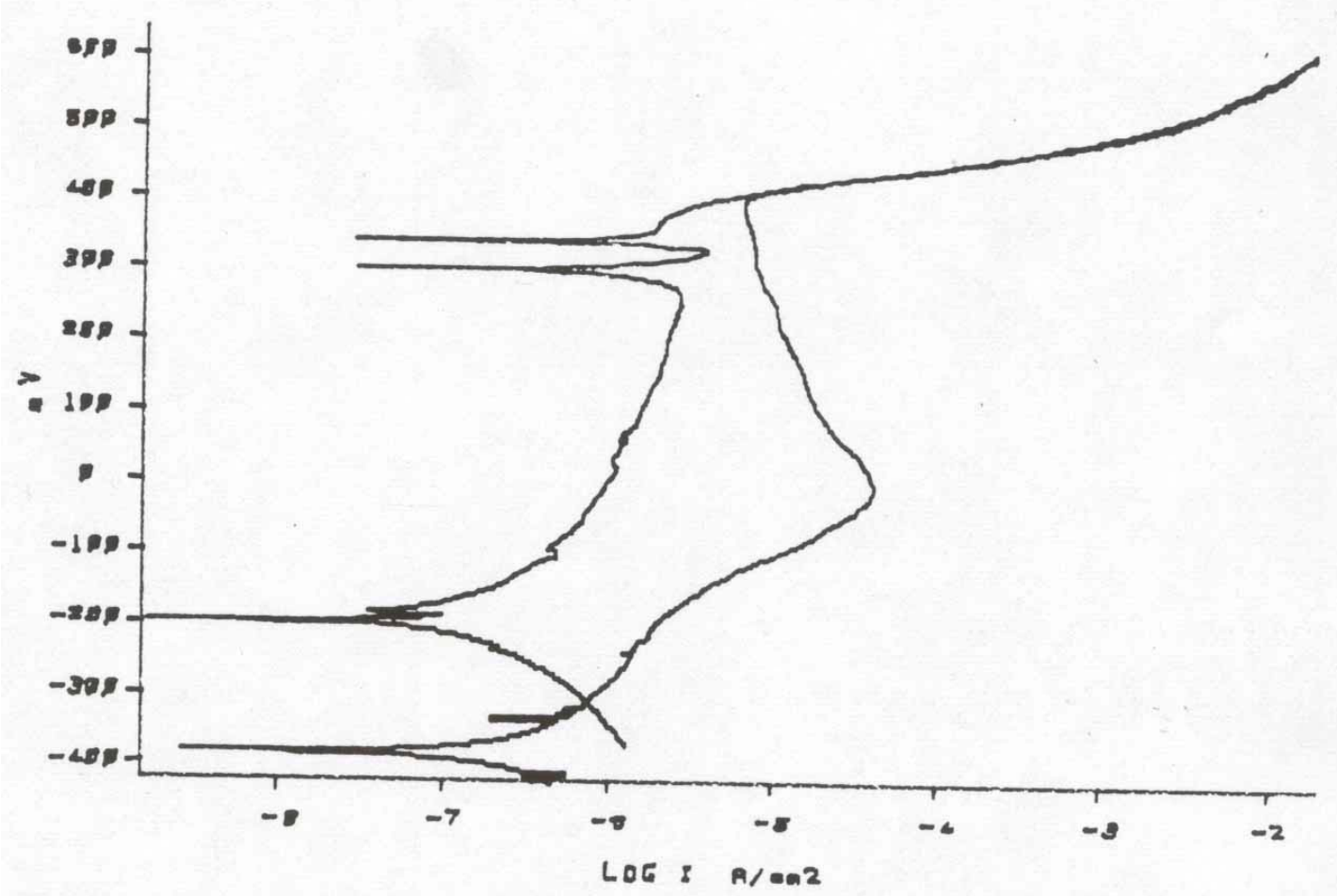

Figure 6. Polarization curve showing the corrosion behavior of 304L stainless steel in Solution \#1 at $60{ }^{\circ} \mathrm{C}$. 
Table 7. General Corrosion Rates for 304L Stainless Steel Exposed to Simulated Waste Environments. Rates are in mils per year (mpy).

\begin{tabular}{|c|c|}
\hline Solution & $\begin{array}{c}\text { Average Corrosion Rate } \\
\text { (mpy) }\end{array}$ \\
\hline 1 & 0.010 \\
\hline 4 & 0.078 \\
\hline 8 & 0.015 \\
\hline 11 & 0.001 \\
\hline 13 & 0.035 \\
\hline
\end{tabular}

Waste transfer lines associated with the high level waste evaporator system contain waste at higher temperatures (up to $150{ }^{\circ} \mathrm{C}$ at the discharge from the evaporator) and hydroxide concentrations $(>5 \mathrm{M})$. Thus the general corrosion rates may be slightly higher. Chandler performed hot-wall corrosion tests on 304L stainless steel in simulated evaporator solutions [43]. Table 8 shows the composition of the test solution. The temperature at the hot wall was approximately $220^{\circ} \mathrm{C}$. The tests were conducted for 28 days. The general corrosion rate was estimated to be $1.1 \mathrm{mpy}$. It should be emphasized that this is an extremely conservative value for the general corrosion rate as the solution at the hot-wall is essentially maintained at the boiling point temperature, whereas the temperature at the core pipe of the transfer line will be significantly less. For example, although the temperature at the hot-wall was $220^{\circ} \mathrm{C}$, the actual temperature of the liquid a short distance away is approximately $118^{\circ} \mathrm{C}$.

Table 8. Composition of Simulated Evaporator Solution

\begin{tabular}{|l|r|}
\hline Species & Molarity \\
\hline $\mathrm{NaOH}$ & 5.44 \\
\hline $\mathrm{NaNO}_{3}$ & 2.26 \\
\hline $\mathrm{NaNO}_{2}$ & 2.39 \\
\hline $\mathrm{NaAlO}_{2}$ & 1.39 \\
\hline $\mathrm{Na}_{2} \mathrm{CO}_{3}$ & 0.25 \\
\hline $\mathrm{Na}_{2} \mathrm{SO}_{4}$ & 0.04 \\
\hline $\mathrm{NaF}$ & 0.004 \\
\hline $\mathrm{NaCl}$ & 0.04 \\
\hline $\mathrm{Na}_{2} \mathrm{SiO}_{3}$ & 0.006 \\
\hline $\mathrm{Na}_{3} \mathrm{PO}_{4}$ & 0.009 \\
\hline $\mathrm{Na}_{2} \mathrm{C}_{2} \mathrm{O}_{4}$ & 0.004 \\
\hline $\mathrm{Hg}_{(}\left(\mathrm{NO}_{3}\right)_{2}$ & 0.0008 \\
\hline
\end{tabular}

\subsubsection{Pitting}

Every engineering metal or alloy is susceptible to pitting, which is a highly localized form of corrosion that produces sharply defined holes in a material. Despite good resistance to general corrosion, stainless steels are more susceptible to pitting than many other metals. Pitting can be a destructive form of corrosion if it causes perforation of 
equipment. However, minor pitting that does not result in perforation is often tolerated and accepted in engineering equipment for economic reasons. Pits may be isolated from each other on the surface or so close together that they resemble a roughened surface (see Figure 7 [39]).

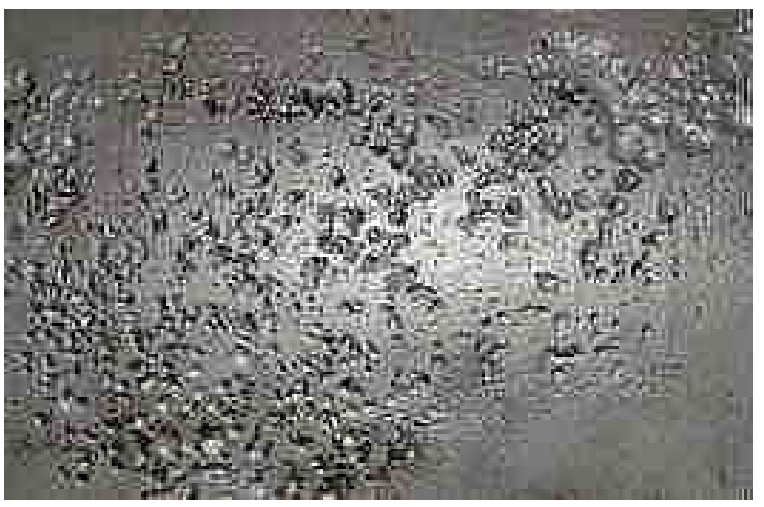

Figure 7. Pitting corrosion on carbon steel [39]. Note that this is not piping from the SRS waste transfer line system.

The focus of much of the literature on pitting has been on understanding the factors that control initiation. There are several potential causes of pit initiation:

a) local inhomogeneity on the metal surface;

b) local loss of passivity;

c) mechanical or chemical rupture of the protective oxide coating;

d) galvanic corrosion from a relatively distant cathode;

e) formation of a metal ion or oxygen concentration cell under a solid deposit;

f) presence of biological organisms.

For stainless steel the most common cause of pit initiation is highly localized destruction of passivity by contact with moisture that contains halide ions, particularly chloride ions [44]. Stagnant or low flow conditions favor the initiation and propagation of pits as well. The tendency for pitting also increases with increasing temperature and chloride ion concentration [41]. Inhibitors such as hydroxide, nitrate, chromate, sulfate and carbonate are added to a chloride bearing solution to reduce the pitting tendency. Although all these species are present, the two primary inhibitors that are present in waste solutions are hydroxide and nitrate. The literature indicates that a $\mathrm{pH}>11$ is sufficient to reduce the pitting tendency of stainless steel in seawater [41]. Given that the waste $\mathrm{pH}$ is typically much greater than 12 and the chloride concentration is much less than that of seawater, pitting in the waste transfer system under normal service conditions due to chlorides is not anticipated.

Electrochemical techniques are utilized to establish whether a metal/alloy is susceptible to pitting in a given environment [45]. The cyclic polarization curve shown in Figure 8 illustrates conditions under which pitting is favorable. In the test, the potential is swept 
in a positive direction from the open circuit value and the current response is monitored. At a peak current density, the direction of the potential sweep is reversed and returned to the open circuit value. If the current density observed during the reverse scan is greater than the forward scan this is an indication that the material is susceptible to pitting. On the other hand, if the current density on the reverse scan is less than or equal to that of the forward scan the material would be expected to remain passive. These types of tests were conducted in the same 5 unconcentrated supernate simulants that were utilized for the general corrosion tests [40]. The test temperatures were 30 and $60{ }^{\circ} \mathrm{C}$. In all cases no pitting susceptibility of the stainless steel was indicated (Note: An example of a cyclic polarization curve that demonstrated no pitting is shown in Figure 6.). Although no testing was performed in the more concentrated waste, the high $\mathrm{pH}$ would also be expected to preclude pitting of stainless steels in these environments.

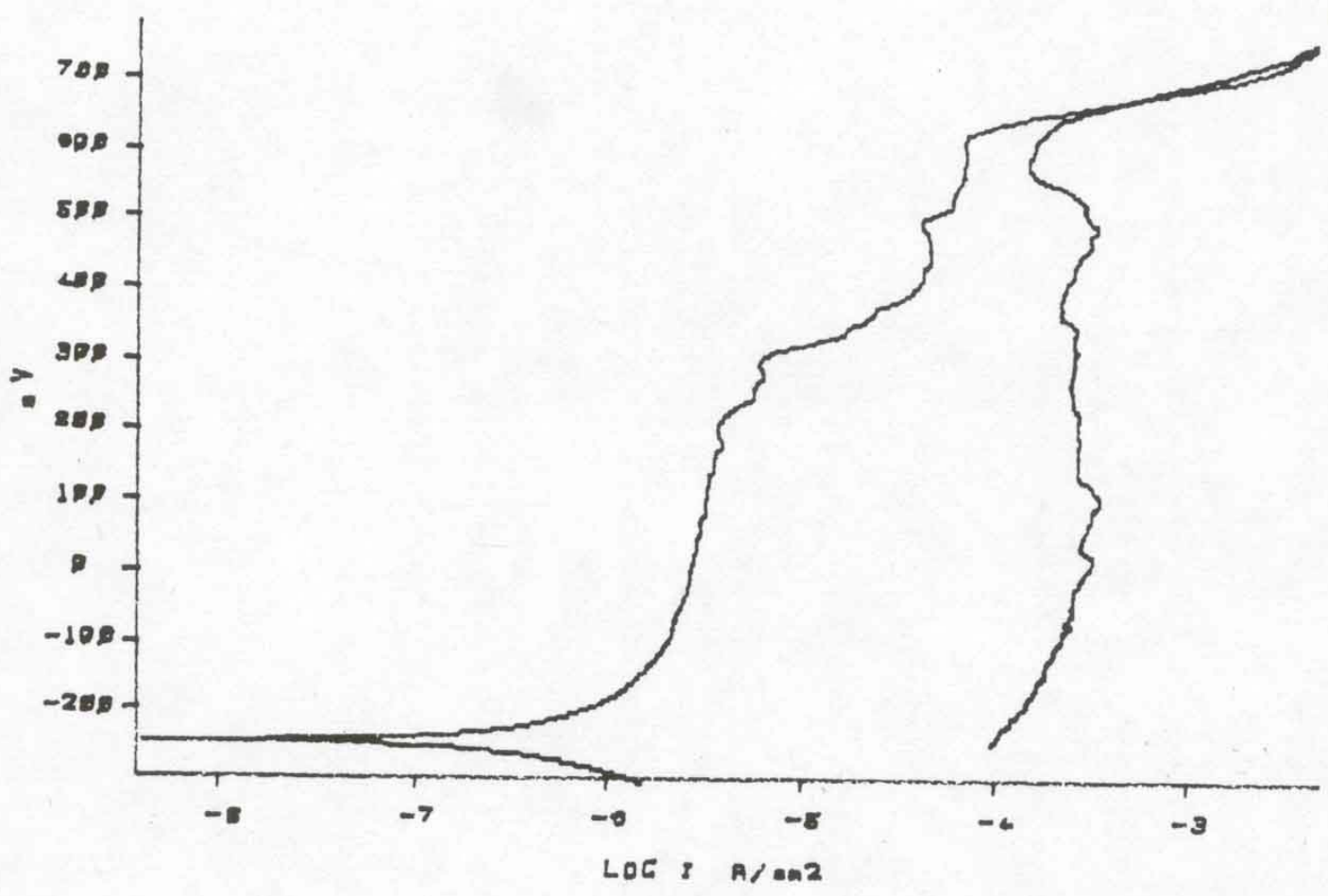

Figure 8. Cyclic polarization curve that demonstrates pitting corrosion behavior. Note that stainless steel in the simulated waste solutions did not show evidence of pitting.

\subsubsection{Stress Corrosion Cracking}

Stress corrosion cracking (SCC) is a general term describing failures that occur by cracking in corrosive environments under load [41]. The requirements for SCC are the 


\section{Page 21 of 69}

presence of a tensile stress (i.e., either residual, applied or a combination of both), the presence of a specific corrodent, and a susceptible material. The cracks form at roughly right angles to the direction of the tensile stress at stress levels much lower than those required to fracture the material in the absence of the corrodent.

On a microscopic level the cracks that run across the grains of the material are called transgranular, while those that follow grain boundaries are termed intergranular. Intergranular cracking generally occurs only in stainless steels that are heavily sensitized. Sensitization refers to the depletion of chromium in the space immediately adjacent to the grain boundary, usually associated with formation of a second phase precipitate high in chromium. This mechanism results in a loss of passivity in the base material adjacent to the grain boundaries. Chromium depletion can occur when the material is held at temperatures between 500 and $700{ }^{\circ} \mathrm{C}$ for periods on the order of 1 to 24 hours, as may occur with welding or fit-up of pipes. The carbon concentration plays a big role in the sensitization mechanism. The carbon reacts with the chromium to form chromium carbides at the grain boundaries, leading to effective removal of chromium and carbon from the alloy. Low carbon stainless steels, such as 304L that contains less than $0.03 \mathrm{wt}$. $\%$ carbon, are less susceptible to sensitization than those stainless steels with higher carbon contents [46].

The stainless steel piping that was placed according to Specification 4482, including the Type II transfer lines, was typically corrosion evaluated 304L. The corrosion evaluation test determines the susceptibility of the pipe material to intergranular attack. A sample of the pipe material that passes the corrosion evaluation test will not be susceptible to intergranular attack and thus the likelihood of intergranular SCC of these transfer lines is minimal.

The stainless steel piping that was placed according to Specification 3018 (i.e., prior to 1961) has the potential to be susceptible to intergranular stress corrosion cracking. The type of steel utilized for this piping was typically 304 stainless steel rather than 304L. The primary difference is that the 304 has a higher carbon content than the 304L $(0.08$ wt. \% vs. 0.03 wt. \%) and as a result the 304 is more prone to chromium carbide formation and sensitization than $304 \mathrm{~L}$. At the time the lines were placed there was no requirement for corrosion evaluation, and therefore there was no quality verification that would indicate that the piping material was not susceptible to intergranular attack. However, Specification 3018 did contain recommended procedures for heat treating the stainless steel piping. The heat treatment process described would have homogenized the material (i.e., restored the depleted chromium region at the grain boundaries) and thereby reduced the susceptibility to intergranular attack. The specification for the 304 stainless steel material that was utilized for piping in the 1950s required that the pipe be in the solution annealed condition. If welding was performed on the pipe, another solution annealing heat treatment was required.

The corrosivity of the environment has also been investigated. High level wastes at SRS are compatible with 304L stainless steel, and will not cause cracking because they are basic nitrate solutions which contain incidental amounts of chloride and fluoride [47]. 


\section{Page 22 of 69}

Stainless steels are most susceptible to stress corrosion cracking in solutions containing halide ions such as chloride. However, the presence of the nitrate ion in basic solution has been shown to prevent stress corrosion cracking by halides [48]. Laboratory testing was performed at SRS to confirm that $304 \mathrm{~L}$ stainless steels were not susceptible to intergranular SCC in simulated waste environments [49]. The tests were performed in the same solutions that were used for the general and pitting corrosion studies at a temperature of $60^{\circ} \mathrm{C}$. The samples were tested in the as-received condition and with a heat treatment designed to simulate a weld region. The slow strain rate or constant extension rate test was utilized to determine SCC susceptibility [50]. The results of the tests showed that $304 \mathrm{~L}$, even in the heat treated condition was not susceptible to SCC [49] (Note: an attempt was made to sensitize the material, but, only minor indications of chromium carbide formation were observed).

Intergranular SCC during normal service in the pipelines is not anticipated for the Type II transfer lines. Although there is less confidence in the resistance of the 304 stainless steel (i.e., material utilized for older transfer lines) to intergranular attack than the 304L stainless steel, the relatively benign high level waste environment and the requirement in the specification to heat treat the welded areas indicate that the possibility of intergranular SCC in these lines is also minimal.

Transgranular SCC is a problem for 300 series stainless steels exposed to solutions that are neutral or acidic ( $\mathrm{pH} 2-8)$. As mentioned previously, increasing the $\mathrm{pH}$ or adding nitrate ions to a solution decreases the tendency for stress corrosion cracking by chloride [47]. Under normal service conditions at SRS, transgranular SCC is not anticipated. However, if natural water (e.g., well water or ground water), which has a neutral to slightly acidic $\mathrm{pH}$, is allowed to contact the stainless steel, problems could arise.

Instances of transgranular SCC have been observed in the waste tank farm. In each case natural water was involved and the chloride ion was observed to be the species that initiated the attack. The first case of SCC was observed on the lines embedded in the concrete wall of the F-Area Concentrate Transfer System (CTS) pit. The piping had been placed according to the revision of Specification 4482 that was applicable at that time. The failure resulted in a loss of confinement of the high level waste [51] (See Figure 9). The line had been insulated with cork and Scotchrap TM 50, a polyvinyl chloride tape. Chemical analysis of samples of the tape revealed that the material contained up to 14,000 ppm chloride [52]. This chloride concentration was well above the presently allowed $250 \mathrm{ppm}$ for materials in contact with stainless steel components. Degradation of the tape freed the chloride ions to participate in the SCC mechanism. Since the CTS pit was below grade, the source of the natural water was the ground [53]. Elevated temperatures also accelerate the corrosion reactions on the stainless steel surface. The temperature of the pipe ranged from ambient to $300^{\circ} \mathrm{F}$ depending on whether waste was present. The high temperatures likely degraded the tape and evaporated moisture such that the chlorides in the solution at the exterior surface of the pipes were concentrated. The pipes were bent as they passed through the concrete wall creating additional tensile stress. Finally, the system had been in service for a significant period of time (i.e., six years). The combination of these factors led to the failure of four of the stainless steel 
core transfer lines as well as several stainless steel service lines (i.e., flush water, steam, etc) that were also embedded in the concrete. As mentioned earlier, the pit wall was repaired by replacing the embedded sections of pipe with new stainless steel pipe enclosed in modular jackets. The jackets provided an enclosed air space around the stainless steel piping, eliminating any contact with chloride bearing materials.

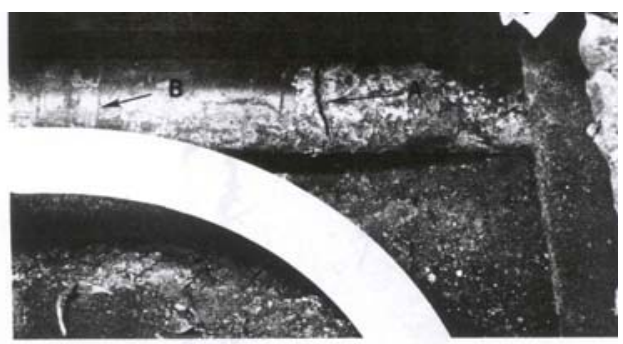

Aprex. $1 / 2 x$

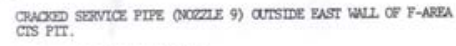

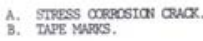

(a)

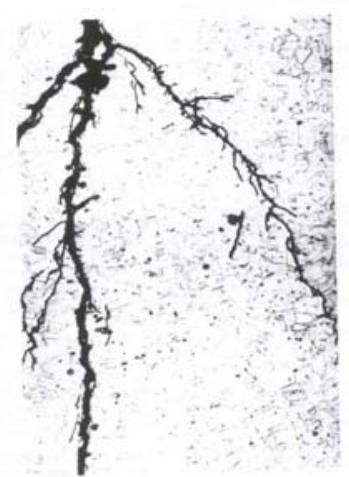

2000 TRANSVERSE SBCTION OF SERVICZ PIPE COOZZIE 9) SHOWING (b)

Figure 9. F-Area CTS pit: (a) View of cracks on stainless steel waste transfer line, and (b) Photograph showing transgranular SCC in the pipe wall cross-section [52].

A review of the design drawing of the H-Area CTS pit indicated that the embedded stainless steel pipes were wrapped with the same insulation tape which had been utilized in the F-Area [54]. Although no failures of the transfer pipes had occurred, one process line had failed. Samples of the tape were analyzed and found to contain up to 38,000 ppm chloride [55]. One reason the H-Area lines may not have failed is they had been inservice for a shorter time than the F-Area lines (four years vs. six years). As a preventative measure, the pit wall was repaired by enclosing the lines in the modular jackets as had been done in F-Area [56]. Following repair of the pit walls there were no incidents of loss of confinement. However, all of these lines have since been retired from service.

Stress corrosion cracking of a stainless steel core transfer line was also observed [57-59] near a clean-out port in the CTS loop for Tanks 29-32 in the early 1980's (See Figure 10). The piping had been placed according to the revision of Specification 4482 applicable at that time. The failures at the clean-out port probably occurred some time between hydrotesting of the system and placing the line in radioactive service. Uninhibited well water was utilized for the hydro-test and is the likely source of the chloride ions. Although the well water is typically low in chlorides (less than $5 \mathrm{ppm}$ ), evaporation may have increased the chloride concentration. Concurrent with this failure, it was discovered that an underground steam line in close proximity to the clean-out port had leaked for an 
Page 24 of 69

extended period of time. During the repair of the steam line, the degree and extent of heated soil in the area was observed to be unusual. The steam leakage was postulated as a heat source which would produce the elevated temperatures necessary to enhance stress corrosion cracking. A time/temperature combination is also required for cracks to initiate and propagate. It was observed that both the extended period of steam leakage and the extended period before the line was placed in service were likely contributors to the failure. It was therefore recommended that the repair time for leaks in buried steam lines be minimized and that new pipe lines should not be held out of service for extended periods of time [59].

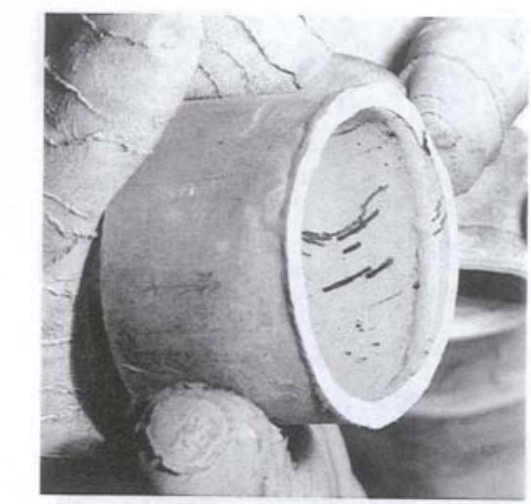

(a)

Section of failed catheter, with dye penetrant illustrating cracks at the leak site.

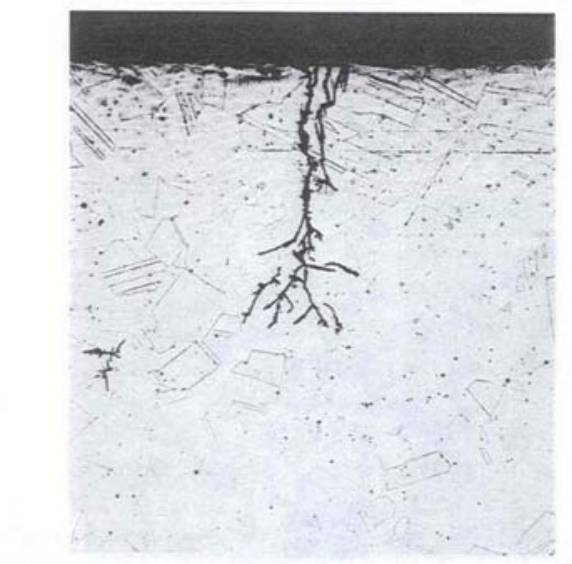

(b)

CSCC in second catheter; origin at the inside surface, 50X.

Figure 10. Section of core pipe from clean-out-port \#3: (a) Dye penetrant test showing cracks on the interior of the pipe, (b) Micrograph showing transgranular SCC [61].

In fact, placing the lines in service with the waste supernate, which has relatively high nitrate and hydroxide concentrations, will protect the stainless steel. Therefore, it has been recommended that the time for which the transfer lines are exposed to stagnant well water at elevated temperatures be minimized. Administrative controls, such as the 
Page 25 of 69

Corrosion Control Program Description Document, are in place to minimize the potential for well water to be left in the lines for extended periods of time [60].

\subsubsection{Microbiologically Induced Corrosion}

Microorganisms can form films and deposits on metals and alloys exposed to aqueous environments. These films and deposits, along with the metabolic activity of the microorganisms may influence corrosion of the exposed metal (See Figure 11 [39]). If these microorganisms accelerate corrosion, it is termed microbiologically induced corrosion (MIC).

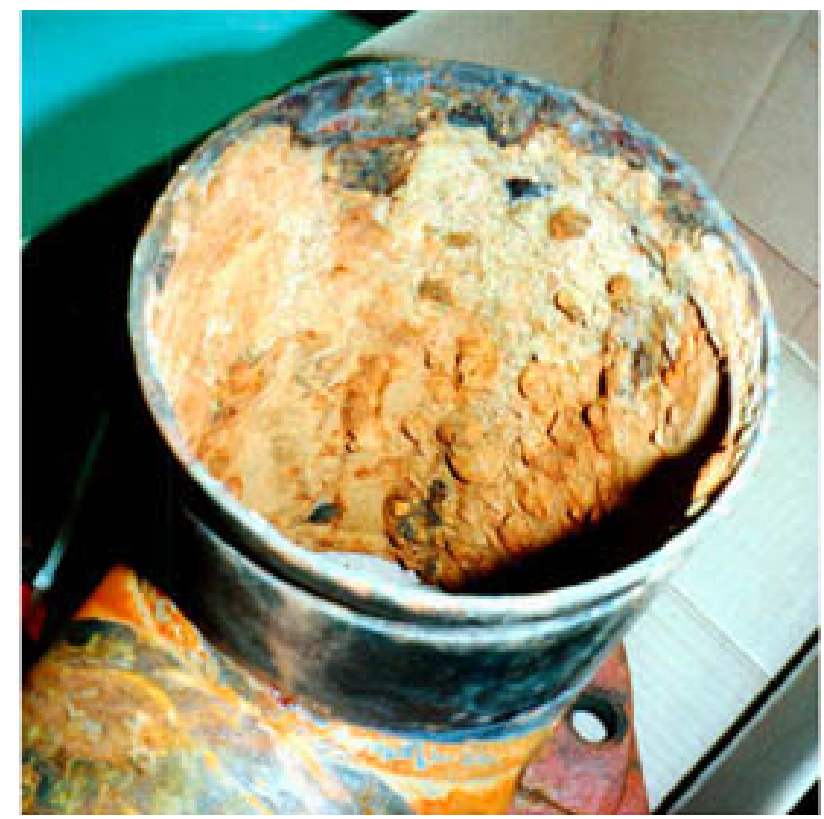

Figure 11. Microbiologically induced corrosion on a pipe [39]. Note that this is not piping from the SRS waste transfer line system.

Microorganisms can be in the form of bacteria, fungi or algae. The characteristics of microorganisms that may influence corrosion processes vary over broad ranges [62]. Some of the characteristics of these microorganisms are:

a) Able to adapt to temperatures between -10 to $99^{\circ} \mathrm{C}$;

b) Able to survive in aerobic and anaerobic environments;

c) Able to adapt to solutions with $\mathrm{pH}$ levels between 0 to about 10. The growth of bacteria associated with corrosion slows considerably above $\mathrm{pH} 11$ and completely stops at $\mathrm{pH} 12.5$ [63, 64];

d) Capable of rapid colonization;

e) Capable of developing synergistic relationships with other microorganisms.

These characteristics allow the microorganisms to induce corrosion in a variety of environments. In some cases the microorganism excretes an acid which lowers the local 
$\mathrm{pH}$. The crevices that form beneath the biofilms/deposits may lead to either oxygen depletion cells or cells with an environment significantly different than the bulk solution, and ultimately leads to crevice corrosion. Still other bacteria may generate hydrogen sulfide under local anaerobic conditions and thereby facilitate hydrogen embrittlement.

Confirmed cases of MIC in industry have generally been associated with cooling water systems, construction lay-up, aqueous waste treatment systems and systems that contain natural water left from hydro-testing or other system evaluation procedures [65]. These situations establish environmental conditions favorable to MIC that include [62]:

a) Low flow $(<5 \mathrm{ft} / \mathrm{s})$ or stagnant liquid;

b) Presence of organic matter;

c) Presence of inorganic material such as nitrite;

d) Interrupted operations;

e) $\mathrm{pH}<10.5$;

f) Absence of a biocide chemical.

Numerous cases have been reported in the chemical process industry in which natural waters left in non-operating stainless steel systems have resulted in MIC [66]. The time periods for the onset of MIC ranged from a few days to ten months.

Austenitic stainless steels (e.g., 304L) are particularly susceptible to MIC. The physical evidence for MIC is the formation of characteristic deposits referred to as tubercles. These deposits are generally adherent and typically lead to localized corrosion. Pitting that occurs is accompanied by sub-surface corrosion in the rolling or working direction of the material (See Figure 12). Selective attack at welds and/or weld heat affected zones is frequently associated with MIC in austenitic stainless steels.

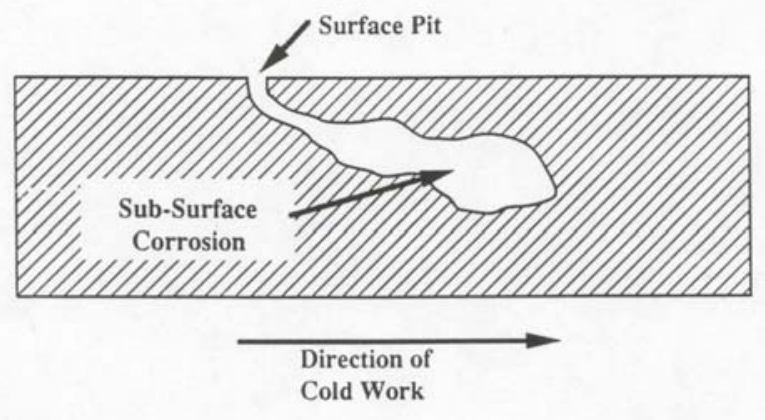

\section{Figure 12. Schematic of pit extension by corrosion in the working direction of the material.}

Samples of water obtained from SRS wells indicate the presence of iron or manganese oxidizing microorganisms [67]. Most of these microorganisms are bacterial, although there are a number of algal cells. The presence of these micro-organisms does not necessarily imply that MIC will occur. Environmental conditions must exist such that the cells multiply and colonize to form the tubercles such that corrosion processes may occur. 
There have been three documented cases of MIC of stainless steel piping at SRS. One case was confirmed, while MIC likely played a role in the corrosion mechanism in the other two cases based on the appearance of the corrosion and the environmental circumstances. The confirmed case of MIC occurred in the Defense Waste Processing Facility (DWPF) in 1991 [67]. During a routine walk-through inspection of the Melter Cooling Water System (MCWS), rust colored "bleed-through" was observed on the exterior of the piping near the welds (See Figure 13). Approximately $1 / 3$ of the welds in the piping showed evidence of leakage. The MIC presumably occurred because the MCWS was originally tested and flushed with neutral water that was not chlorinated or treated with any biocide. When water quality problems were noted, the system was drained and flushed with de-ionized water that was not treated. The water was left stagnant in the line for several months.

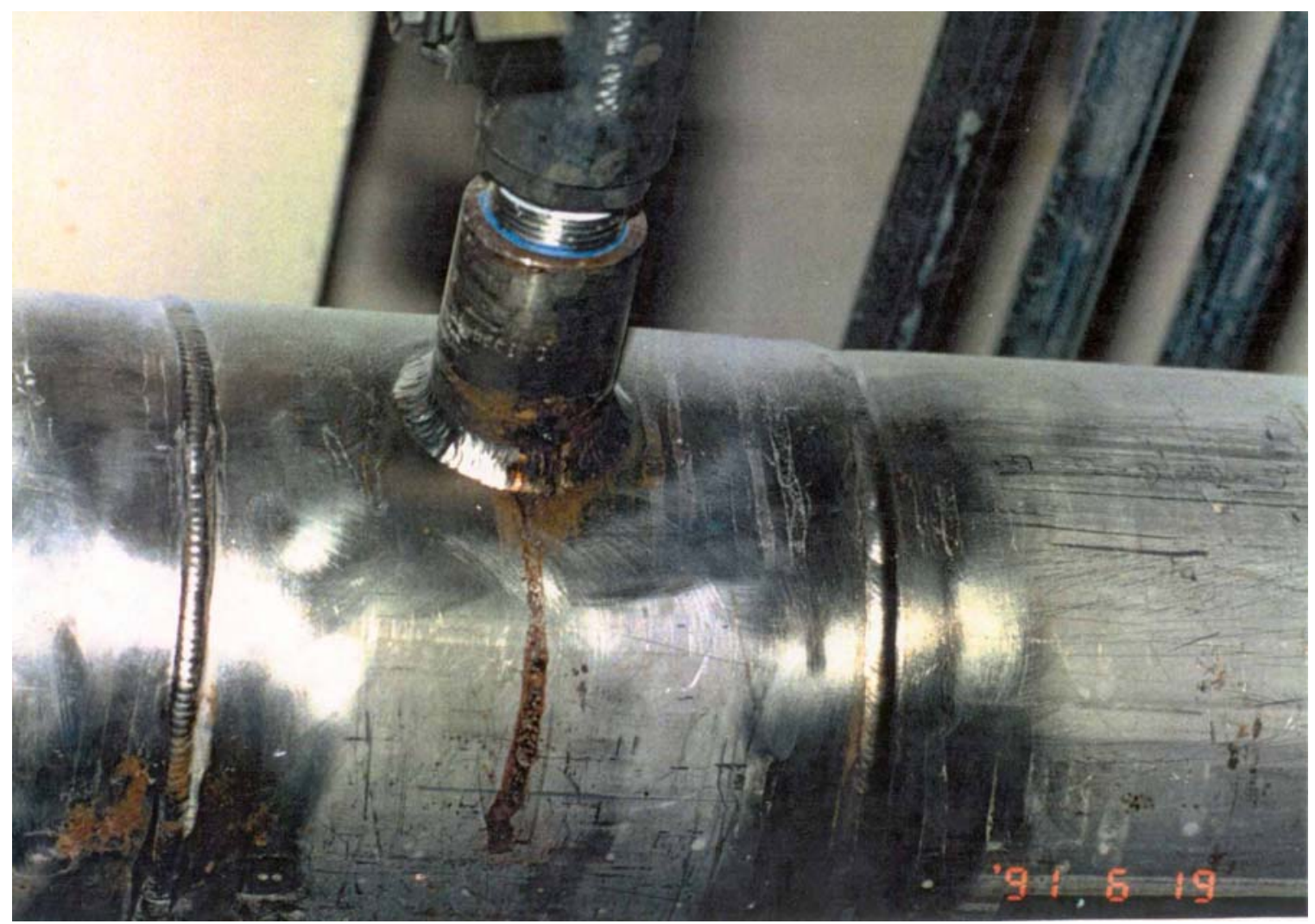

Figure 13. Evidence of MIC on the exterior of the cooling water pipe in the DWPF [67].

Evidence of tubercles was observed on the interior of the pipe near the welds (see Figure 14). The MIC colonies were tested and it was determined that the attack was due to iron and manganese oxidizing bacteria. Metallographic observations of the failed pipe showed that pitting corrosion occurred with the development of large sub-surface voids near welds (see Figure 15). From Figure 16 it can also be seen that preferential corrosion occurred along the interfaces of the two phase dendritic structure of the weld filler metal. 
Page 28 of 69

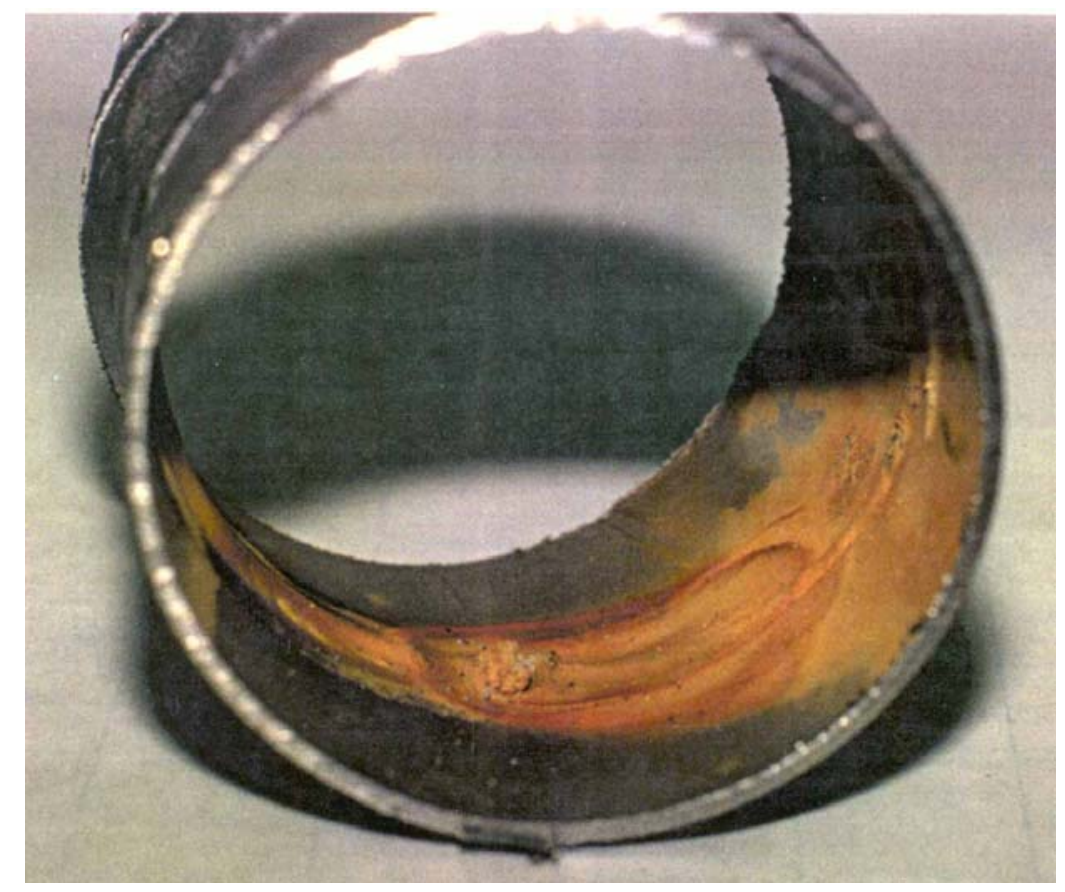

Figure 14. Dry tubercle and ring stains on pipe weld associated with MIC [67].

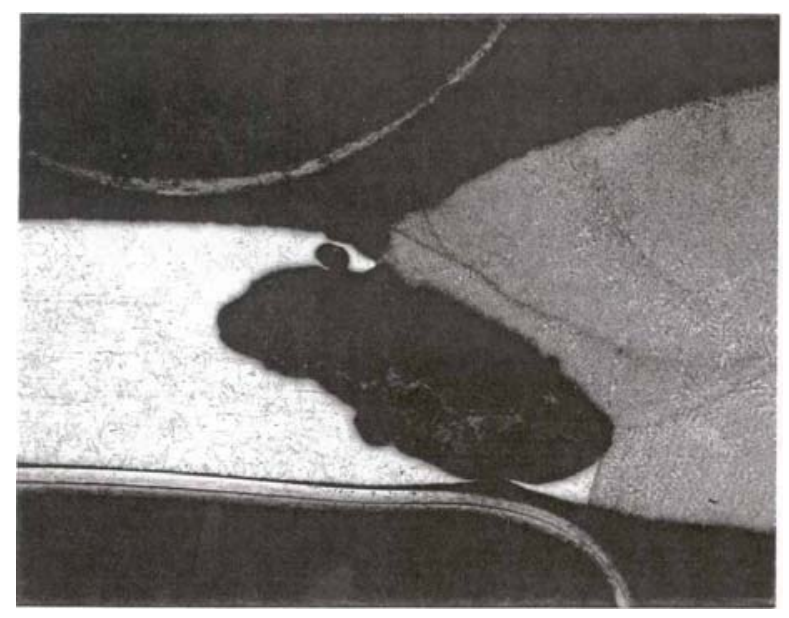

Figure 15. Macroview of pipe wall section at weld that shows evidence of MIC. Void caused by corrosion traverses entire cross-section [67]. 


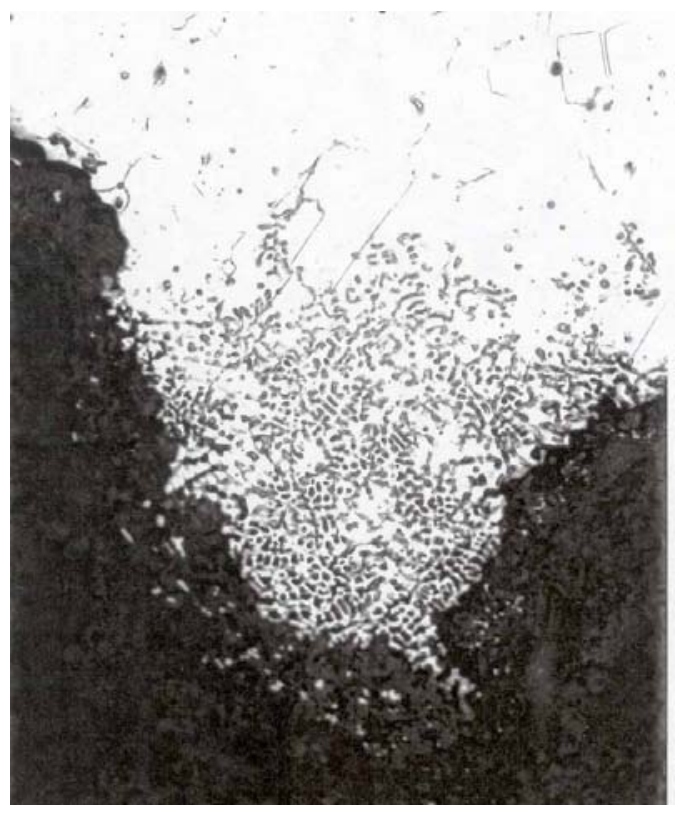

Figure 16. Preferential corrosion of weld filler material in the vicinity of the MIC attack [67].

The MCWS is a "Class 2" system and was not subjected to the rigorous inspection practices employed for waste transfer systems [62]. In general, the welds for the MCWS were of poor quality and provided many flaws and crevices for the bacteria to colonize and grow.

MIC is also suspected as the primary cause of leakage from a cooling water header inside the 221-H canyon facility [68]. The sections of the header affected were the farthest from the supply, and the flow was essentially non-existent between 1986 and 1991. The leaks occurred on, and near, several welds on the header. A total of 13 welds were observed to contain pitting. A brown deposit and staining was observed on the exterior of the pipe at the leak site. Radiographic examination of the pipe wall revealed the presence of voids primarily at the bottom of the pipe where mud had deposited. The pipe was sectioned in these areas where voids were discovered and destructive metallography was performed. Preferential attack of the weld zone similar to that discovered in the MCWS was evident (see Figure 17) and the attack initiated at the toe of the weld. The void itself indicated that corrosion proceeded along grain boundaries and resulted in grain dropping of the austenitic phase (see Figure 18). During internal inspections of the pipe, samples of mud were collected and analyzed for microbes. Tests for anaerobic, sulfate reducing, and acid-producing types of microbes were positive. No tubercle formations were observed at the location of the voids. However, it remains possible that less-rigid masses of organisms and corrosion products had existed and were disturbed by the mud. 


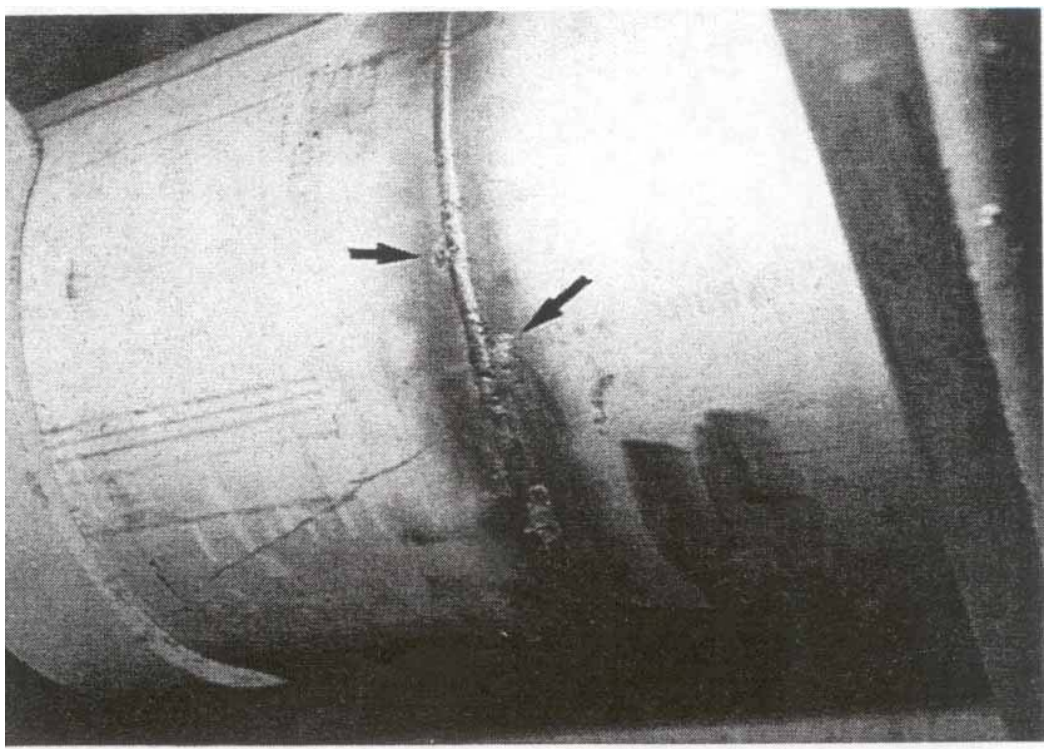

Figure 17. Leaks were located near circumferential welds [68].

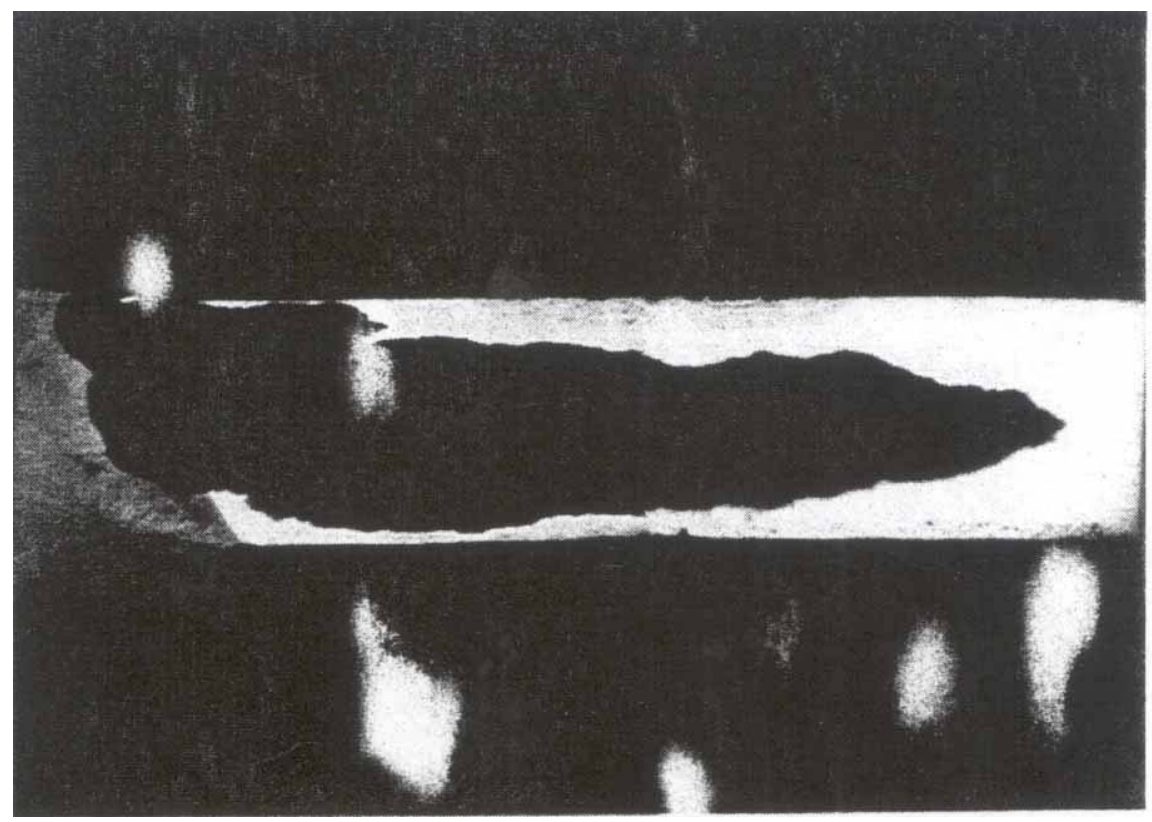

Figure 18. Cross-section of the pipe wall showing sub-surface attack [68].

The third case involved two parallel plate heat exchangers, which are also a part of the MCWS [69]. The heat exchanger consists of parallel plates of 304L stainless steel, each with an elastomer seal glued to one face. The coolant in this case was untreated deionized water. Deposits were observed between the plates, though corrosion tended to be on the side where the gasket was not attached. There was strong evidence for MIC in that the deposits had the appearance of tubercles and the microbe concentration in the water tower was high. The type of attack was somewhat atypical, however, in that no sub- 
surface pitting or voids were evident. The small thickness of the plate may have precluded the development of any extensive sub-surface pits.

Another improper lay-up led to another concern about MIC in the transfer lines between the H-Area waste tank farm and the DWPF [62]. In 1989 it was discovered that two of the inter-area transfer lines between the auxiliary and low-point pump pits had inadvertently been laid up with water for approximately two years. The neutral water remained after hydrotesting and was contained in the annulus between the stainless steel core pipe and the carbon steel jacket. Three inspections were performed to investigate the possibility of MIC [70]. The first inspection consisted of a visual inspection originating at the nozzle boxes of the auxiliary and low-point pump pits. Video probe equipment was extended into the annular region for approximately 30 feet. All of the welds were generally clean with no evidence of MIC. A hydrotest was performed on the core pipe following this inspection. The lines passed the test which was performed at 375 psig. While this test cannot be used to conclude that MIC did not occur, it demonstrates that the line is structurally intact and no through-wall penetration has occurred. Later construction was required to remove a 307 foot section of the suspect transfer line near the auxiliary pump pit. The removed portion was in two pieces allowing for complete inspection of the segments. Video equipment was utilized to inspect 57 feet of annulus space that contained four butt-welds. No evidence of MIC was found. Although it could not be determined if MIC had occurred (only 20\% of the line had been inspected), it was concluded that no significant MIC had occurred.

During normal service, the high $\mathrm{pH}$ of the waste precludes growth of colonies that could cause MIC. On occasion the stainless steel transfer line is exposed to neutral water, primarily for flushing of the line after a transfer. In order to prevent conditions that would be favorable to MIC, the lines are vented and drained after each flush. The administrative corrosion control program also requires that known "low points" in the transfer line system must be flushed with inhibited water $(\mathrm{pH}>12)$ unless another waste transfer is planned within the next five days [60].

The high $\mathrm{pH}$ of the waste in conjunction with the corrosion controls described above has proven effective in preventing MIC. There have been no observed cases of MIC in the stainless steel radioactive waste transfer core piping in the Tank Farms.

\subsubsection{Erosion/Erosion Corrosion}

Erosion may be defined as accelerated attack due to a rapidly flowing fluid that contains solid particles capable of causing wear of the material [41]. Erosion-corrosion refers to the removal of protective surface films by a flowing corrosive fluid, resulting in wear and exposure of new, active metal to the corrosive fluid and ensuing chemical attack (See Figure 19 [39]). Thus, erosion-corrosion incorporates a mechanical and an electrochemical component. The flowing medium can be a single phase (e.g., liquid) or a dual phase (e.g., solid and liquid). Attack in corrosive environments in the presence of solid particles exhibits a highly directional pattern and is more likely to occur in elbows, bends or T-joints in pipes such as the transfer lines. 


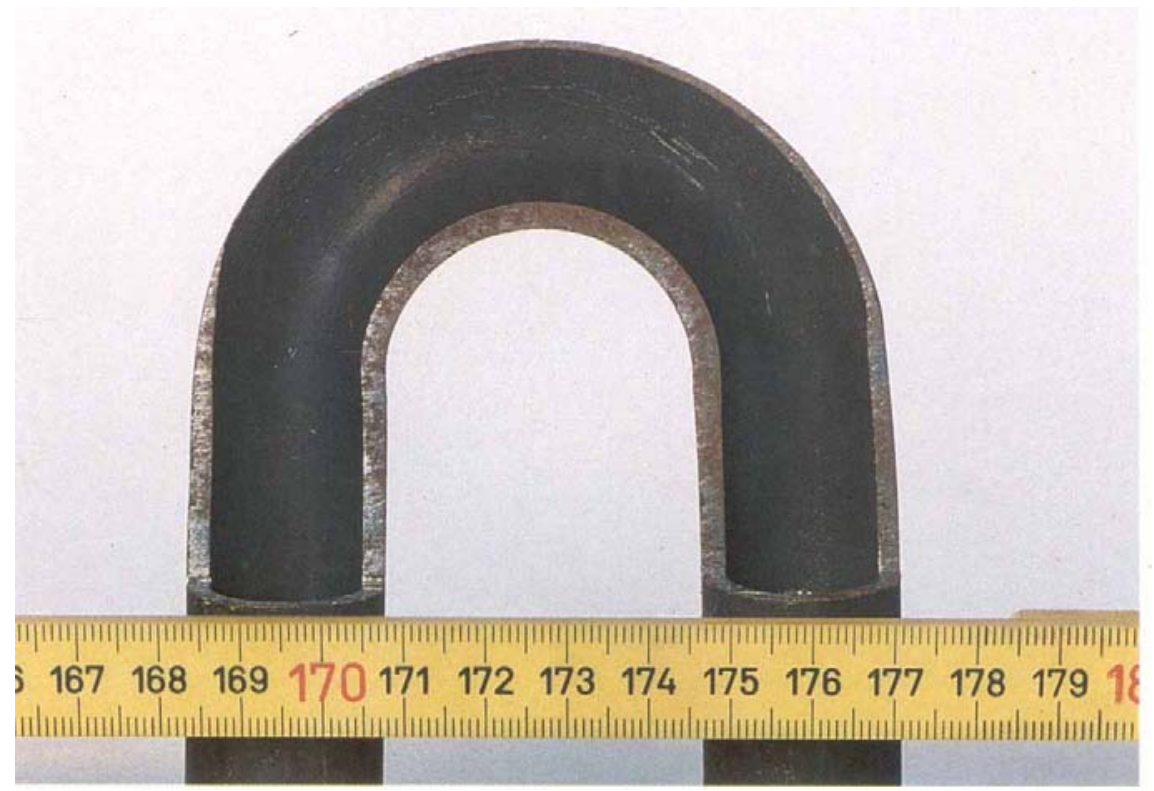

\section{Figure 19. Erosion/Erosion Corrosion on a pipe [39]. Note that this is not piping from the SRS transfer line system.}

The potential for erosion/erosion-corrosion is evaluated by investigating the fluid corrosivity, the relative solids particle hardness compared to the piping material hardness, the particle size, and the fluid velocity. Other factors that may accelerate material loss include turbulence (turbulent flow causes greater erosion-corrosion than laminar flow), particle angularity, and the angle of impingement (e.g,. sharp elbows in piping where the fluid is forced to turn its direction of flow). Potentially the most severe conditions occur with sludge slurry transfers that contain metal oxides and DWPF recycle transfers that contain small amounts of glass frit carry-over (silica is harder than most metals).

The corrosivity of waste solutions, similar to sludge slurry or DWPF recycle solutions, toward 304L stainless steel was discussed previously. All the results indicate that 304L stainless steel is essentially immune to both general and pitting corrosion in these alkaline solutions $[40,42]$. Thus, in the case of the waste transfer piping the corrosion component of the mechanism is significantly reduced.

Erosion damage depends on the hardness and size of the particles in the fluid. Erosion will occur when the impacting particles in a slurry have a hardness greater than or equal to that of the structural material. Larger particle sizes also tend to result in more erosion damage. Type 304L stainless steel has a Brinell Hardness Number (BHN) of 143 [71]. High level waste sludge contains oxides of iron, manganese, aluminum, etc. Particles of these oxides do have a sufficiently high hardness (BHN on the order of 500) to erode stainless steel [72]. On the other hand sludge particle sizes tend to be on the order of 3 $\mu \mathrm{m}$ [73] which tends to lessen the effect. In comparison, however, the particles are much smaller and softer than ordinary sand which has a BHN of approximately 1000 [74] and can be very abrasive. 
The fluid velocity for sludge slurry transfers depends on the size of the pump that is utilized to transfer the sludge and on the wt. \% of insoluble solids. For example, for recent sludge removal operations in Tank 8 , the flow rate needed to suspend $10 \mathrm{wt} . \%$ insoluble solids was approximately 100 to 110 gallons per minute or a velocity of approximately $5 \mathrm{ft} / \mathrm{s}$ [75]. The flow rate is actually bounded by the capacity of the pump that is utilized. Pumps at SRS are capable of flow rates up to approximately 160 gallons per minute or $7.3 \mathrm{ft} / \mathrm{s}$. The velocity will be compared with velocities from experimental work to assess the potential for erosion.

Representative laboratory-produced sludge slurries, with particle size, composition and solution corrosivity $(\mathrm{pH} \sim 13)$ similar to SRS sludge slurries, were tested at Pacific Northwest National Laboratory (PNNL) to determine the susceptibility of carbon steel to erosion-corrosion during slurry pump operations [76]. The tests were performed at 103 ${ }^{\circ} \mathrm{C}$ and a fluid velocity of $15 \mathrm{ft} / \mathrm{s}$. A maximum erosion-corrosion rate of 4 mpy was measured. In another test, Hoey and Bednar measured the erosion-corrosion rate for both stainless steel and carbon steel in aerated, chloride slurry that contained coal fines [77]. The erosion-corrosion rate for the stainless steel was approximately 10 times less than that for the carbon steel. Although the solution in these tests is more corrosive and the particles more abrasive than the SRS sludge slurries, the same relationship between the stainless steel and carbon steel erosion corrosion rates is reasonable and will be adopted for this evaluation. Given the data from PNNL, an estimate for the erosion-corrosion rate of the stainless steel transfer lines is 0.4 mpy [72]. This value is conservative as the velocity during the maximum velocity during a sludge transfers is approximately half that of the PNNL tests and the temperature the temperature during the transfer is usually less than $50^{\circ} \mathrm{C}$. This wall thinning rate also assumes a continuously flowing system. The infrequency of sludge slurry transfers further reduces the possibility for significant erosion corrosion of the piping. Usage factors, which estimate the time the pipe is exposed to flowing sludge slurry, were determined to estimate the actual wall loss for a given period of time (see Section 6.1.2).

Early in the DWPF process development, the abrasive effect of both glass frit and sludge on process equipment was addressed. The DWPF frit has a larger particle size and is more abrasive than the SRS sludge. Laboratory studies performed to assess the erosion resistance of 304L stainless steel included three separate erosion test loops and the Miller Abrasivity Test [78]. The piping for the test loops contained both straight sections and elbows. The fluid velocities tested ranged between 3 to $20 \mathrm{feet} / \mathrm{s}$. The fluid was circulated through the pipes for between 200 to 1350 hours. The wt. \% solids for the slurries utilized in the tests tended to be very high ( $40 \mathrm{wt} . \%)$ compared to that of the feed stream to DWPF ( $\sim 10 \mathrm{wt} . \%)$ and the DWPF recycle stream $(\sim 0.14 \mathrm{wt} . \%)$ that are being sent to the tank farm. Post-test ultrasonic thickness measurements of the piping indicated no wall loss due to erosion.

Field experience in the DWPF was also utilized to assess the potential for erosioncorrosion due to the frit [79]. The Slurry Mix Evaporator (SME) permanent sample line system and the canister decontamination system handle solutions containing 


\section{Page 34 of 69}

approximately $40 \mathrm{wt} \%$ and $8 \mathrm{wt} \% \%$ frit, respectively. Both systems are constructed of Hastelloy C276, an alloy that is expected to have similar erosion-corrosion resistance to stainless steel. No significant wall thinning or erosion of the components was observed after 1 year of operation.

During the initial period of operation of DWPF, foaming occurred in the slurry mix evaporator (SME). As a result, frit became entrained in the overhead stream that was sent to the recycle collection tank (RCT). The contents of the RCT were then $\mathrm{pH}$ adjusted to greater than 12 and then recycled back to the tank farm. The average solids carry-over was expected to be approximately 0.14 wt. $\%$ (0.09 wt. $\%$ frit +0.05 wt. $\%$ sludge solids) [80]. The actual frit carry-over since the facility began operating has been monitored. The concentration of lithium is used to estimate the amount of frit solids carry-over and the concentration of iron is used to estimate the amount of sludge carryover. In most cases the levels of lithium are below detectable amounts (less than $30 \mathrm{ppm}$ ) indicating frit carry-over is small [81]. The iron levels were also frequently below detectable (less than $200 \mathrm{ppm}$ ) indicating sludge carry-over is also small. The low levels of frit carry-over are due to the fact that foaming in the SME is currently being controlled. As long as foaming is kept under control, frit carry-over is insignificant.

Tests performed on slurries of "fresh" glass frit (i.e., large particles with sharp-edged corners) indicated that the frit is more abrasive than the pure white silica sand utilized for the standard Miller tests [78]. However, the frit that the tank farm transfer lines are exposed to likely will not be "fresh". As part of the DWPF process, the frit is agitated with an impeller in the slurry mix evaporator (SME). As a result, the glass particles are broken up and the edges of the particles become more rounded. These smaller, rounder particles are likely more representative of a majority of the frit carry-over to the tank farm. Tests were also performed on glass frit which had been agitated with an impeller. Slurries that contained frit which had been agitated were much less abrasive [78]

Frit carry-over from the DWPF recycle stream is not expected to be an erosion-corrosion concern for the waste transfer lines. This conclusion was based on the relatively small amount of frit carry-over, the low fluid velocity (i.e., less than $5 \mathrm{ft} / \mathrm{s}$ ), and the minimal amount of erosion-corrosion observed in DWPF systems that had significantly more frit compared to frit carry-over to the tank farm. The erosion rate is likely between the general loss rate for stainless steel in high level waste $(0.078 \mathrm{mpy})$ and that indicated for the sludge slurry (0.4 mpy [72]). The rate will be conservatively assumed to be $0.2 \mathrm{mpy}$. The low usage of the transfer lines associated with the DWPF recycle stream reduces the possibility for significant erosion corrosion of the piping. [Note: Usage is a function of the frequency of transfers and the time it takes to make a transfer.] Usage factors, which estimate the time the pipe is exposed to flowing sludge slurry, were determined to estimate the actual wall loss for a given period of time (see Section 6.1.2). 


\subsubsection{Thermal Fatigue}

Thermal expansion or contraction caused by temperature changes may act against a constraint and result in thermal stresses. Temperature gradients along and through the material, internal or external structural constraint, and numerous short-term heating and/or cooling cycles are necessary for thermal fatigue to occur. Low cycle, high stress thermal fatigue was identified as the cause of leakage in the stainless steel core pipe of one high level waste transfer line (see Figure 20 [9]). Transfer line \# 501, which is near the $1 \mathrm{H}$ evaporator, failed in a straight, anchored section of the core pipe. The combination of anchoring the internal pipe to the jacket, restricting the space for expansion, and having multiple lines within the same jacket intensified the stresses on the transfer line. The line had been in service for approximately 4.5 years and had experienced approximately 5500 thermal cycles [9]. The cycles resulted from transfer of concentrated waste from the evaporator at $115-135^{\circ} \mathrm{C}$ alternated with desalination backflushes with water at $20-50{ }^{\circ} \mathrm{C}$. The 502 transfer line, which is adjacent to the 501 line in the same carbon steel jacket, also showed indications of cracks at the anchor plate between the jacket and the core pipe. This second line had been in service for only six months and had experienced approximately 100 thermal cycles.

A comprehensive piping flexibility study was performed in 1980 to identify other lines which may be susceptible to thermal fatigue [10]. The study encompassed 72 different piping systems and included 152 transfer lines. These transfer lines involved Tanks 1-37 and 44-47. The analysis was performed with the computer program PIPELINE ${ }^{\mathrm{TM}}$ with ANSI/ASME pressure piping code stress intensification factors and allowable stress criteria. The actual operating conditions that each line had experienced (i.e., waste and flush temperatures, frequency of transfers, flushes and shutdowns, etc.), and was projected to experience in the future, were utilized in calculations to project the total usage cycles for each line. The dimensions of the lines, the distances between elbows, and the constraints on the lines were also considered.

On the basis of the analysis, three transfer lines indicated high stress areas subject to fatigue [82]. These are listed in Table 9. The lines most susceptible were those associated with the evaporators and the Concentrate Transfer System (CTS). In each case, the high stress locations were at core to jacket anchors. To reduce the likelihood of failure the projected total usage cycles were reduced by increasing the flush water temperature from $20^{\circ} \mathrm{C}$ to $120-135^{\circ} \mathrm{C}$. In addition, a higher level of surveillance was performed [82]. It should also be noted that the lines associated with the CTS are no longer in service.

Piping flexibility analyses are routinely performed on new transfer lines [83]. Thus any piping that has been designed and installed since 1980 has also been analyzed.

\subsection{Carbon Steel Jacket Pipe}

Corrosion is a chemical or electrochemical reaction between a material, usually a metal, and its environment that produces a deterioration of the material and/or its properties. In 
Page 36 of 69

the case of the jacket, the material is carbon steel and the environment is the soil. Corrosion occurs through the loss of metal ions at anodic areas on a structure. At the anode, the base metal is oxidized to form positively charged metal ions which combine with the negatively charged ions in the soil, with the subsequent formation of metal oxide corrosion products. At the cathode the surplus of electrons from the anode combine with positively charged hydrogen ions from the soil environment to form hydrogen and a passivating film on the metal surface.

Table 9. Summary of Thermal Fatigue Analysis for Transfer Lines

\begin{tabular}{|c|c|c|c|}
\hline $\begin{array}{l}\text { Line } \\
\text { Number }\end{array}$ & $\begin{array}{l}\text { Potential Failure } \\
\text { Locations }\end{array}$ & $\begin{array}{l}\text { Recommended } \\
\text { Remedial Actions }\end{array}$ & $\begin{array}{l}\text { Implemented Remedial } \\
\text { Actions }\end{array}$ \\
\hline 303 & $\begin{array}{l}\text { The } 1.5^{\prime} \text { core pipe between } \\
\text { the cleanout port and the } \\
\text { evaporator. Most likely in } \\
\text { the evaporator building at } \\
\text { either the final elbow or the } \\
\text { kickplate where the core is } \\
\text { anchored. }\end{array}$ & $\begin{array}{l}\text { Increase temperature of flush } \\
\text { water from } 20{ }^{\circ} \mathrm{C} \text { to } 135^{\circ} \mathrm{C} \text {. } \\
\text { Maintain high level of } \\
\text { surveillance. }\end{array}$ & $\begin{array}{l}\text { Flush water temperature } \\
\text { increased to } 85^{\circ} \mathrm{C} \text {. } \\
\text { Monitoring increased. } \\
\text { Usage of line until } 1990 \\
\text { permitted. If utilized beyond } \\
\text { 1990, replacement of the line } \\
\text { was recommended. All lines } \\
\text { associated with the } \\
\text { operations of evaporators } \\
\text { will need to be reviewed at } \\
\text { this time. }\end{array}$ \\
\hline 509 & $\begin{array}{l}\text { The core to jacket anchor } \\
\text { within the cleanout port. } \\
\text { The core to jacket anchors } \\
10 \text { ' south and } 100 \text { ' north of } \\
\text { the cleanout port. }\end{array}$ & $\begin{array}{l}\text { Increase temperature of flush } \\
\text { water from } 20^{\circ} \mathrm{C} \text { to } 120^{\circ} \mathrm{C} \text {. } \\
\text { Maintain high level of } \\
\text { surveillance. }\end{array}$ & $\begin{array}{l}\text { Current plans were to } \\
\text { continue to utilize this line } \\
\text { under the same operating } \\
\text { conditions until } 1984 \text { when } \\
\text { Tanks } 29-32 \text { would be full of } \\
\text { salt. At that time, this CTS } \\
\text { loop would be retired. A } \\
\text { design for a replacement line } \\
\text { was requested in case future } \\
\text { use of this line was } \\
\text { necessary. }\end{array}$ \\
\hline 452 & $\begin{array}{l}\text { The core to jacket anchors at } \\
\text { Cleanout Port \# } 3 \text { and east of } \\
\text { of Cleanout Port \# } 3 \text {. }\end{array}$ & $\begin{array}{l}\text { Reduce projected usage of } \\
\text { this line. Maintain high level } \\
\text { of surveillance. }\end{array}$ & $\begin{array}{l}\text { A thermocouple was } \\
\text { installed on the vent line to } \\
\text { warn when the line begins to } \\
\text { plug. Concentrate draw-off } \\
\text { would then be stopped to } \\
\text { prevent thermal cycling of } \\
\text { the line. This improvement } \\
\text { would reduce the number of } \\
\text { thermal cycles the line would } \\
\text { experience. }\end{array}$ \\
\hline
\end{tabular}




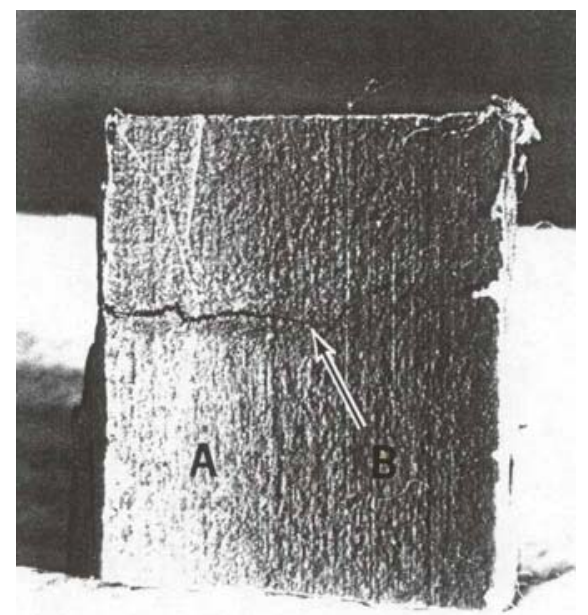

(a)

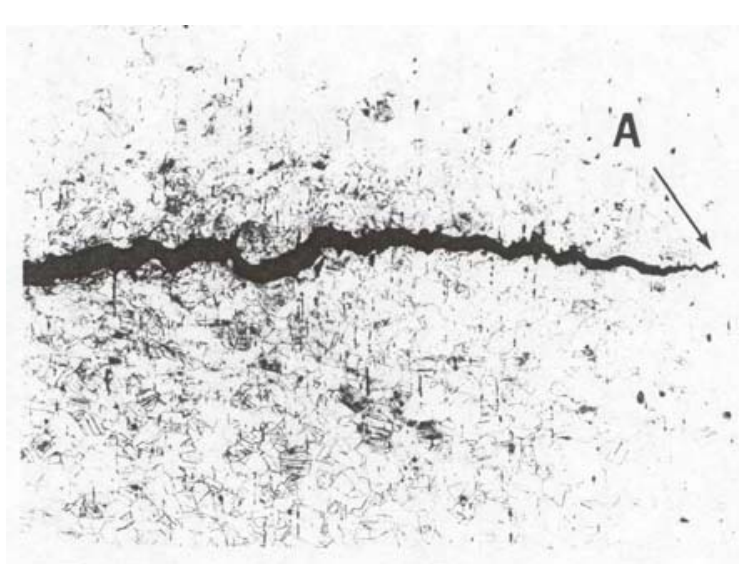

(b)

Figure 20. Fatigue crack of 501 transfer line (near 1-H Evaporator): (a) View of interior surface of pipe, (b) Micrograph showing the fatigue crack [9].

Soil characteristics that influence the type and extent of corrosion of steel include [84]:

a) aeration and permeability characteristics of the soil;

b) soil acidity $(\mathrm{pH})$;

c) dissolved salt content and electrical resistivity of the soil.

Aeration and permeability are the primary attributes of soil that impact corrosion due to the fact that they control the access of oxygen and water to the steel surface. Aeration and permeability characteristics of the soil are dependent on physical characteristics such as particle size, particle size distribution, degree of compaction, and specific gravity. Aeration also depends on the topography of the area, the depth to the water table and the amount of rainfall. 
Corrosion occurs to a lesser degree in soils that are porous, have good drainage and an ample oxygen supply (e.g., sandy soils). Clay soils which tend to have high water retention, poor aeration and poor drainage have significantly higher corrosion rates. Corrosion can also result by differential aeration. For example if a structure or pipe passes through two soils that differ in oxygen permeability, a galvanic current may flow from the region of poorly aerated surfaces (i.e., anode) to the region of aerated surfaces (i.e., cathode). Lower oxygen concentrations typically occur at the bottom of a buried steel structure than at ground level because the soil is more compact and farther from the source of oxygen in the atmosphere. Thus the bottom of the buried structure is potentially more susceptible to corrosion. Oxygen concentration cells can form at random in backfilled soils due to the presence of rocks and other foreign materials. Poorly aerated soils favor pit growth and are known to be corrosive to carbon steel [85].

The acidity or alkalinity of the soil also factors into the corrosion response of a material in soil [86]. Steel in an acidic environment $(\mathrm{pH}<4)$ tends to corrode rapidly in a general or uniform mode. In a neutral to slightly alkaline environment $(4<\mathrm{pH}<10)$ pitting corrosion tends to predominate, becoming less aggressive as the $\mathrm{pH}$ increases. In alkaline environments $(\mathrm{pH}>10)$, steel corrosion is minimal due to the stability of the passive oxide film on the metal surface.

The most corrosive soils are those that contain large concentrations of soluble salts (e.g., chlorides). The soluble salts result in soils that have low electrical resistivities. Soil resistivity measurements are readily attainable and these trend well with corrosivity levels of the soil. Therefore, resistivity is the property most commonly used to approximate the aggressiveness of a soil. Table 10 shows the general relationship that exists between soil resistivity and the corrosion of steel in soils [84]. Backfilled soils may have a lower resistivity due to the accumulation of salts in these areas. Caution should be utilized in applying these classifications blindly, however, as aeration and soil acidity also factor into the corrosive soil conditions. Additionally, resistivity measurements may vary over time due to changes in the moisture content of the soil.

Table 10. Soil Corrosivity vs. Resistivity [84]

\begin{tabular}{|c|l|}
\hline Resistivity, ohm -centimeter & Corrosiveness \\
\hline Below 500 & Extremely Corrosive \\
\hline $500-1,000$ & Corrosive \\
\hline $1,000-2,000$ & Moderately Corrosive \\
\hline $2,000-10,000$ & Mildly corrosive \\
\hline Above 10,000 & Progressively less corrosive \\
\hline
\end{tabular}

To assess the potential for underground corrosion at SRS, the soil characteristics were reviewed and are summarized below:

a) Moisture content from soil samples averaged from approximately $9 \%$ to approximately $38 \%[87,88]$. 
b) In general the soil texture at SRS has been classified as a clayey sand or sandy clay that contains 20 to $40 \%$ clay [89]. The texture contributes to the well drained and excessively drained soil characteristics in most areas at SRS [90].

c) $\mathrm{pH}$ ranges from acidic to slightly alkaline ( $\mathrm{pH}$ of 3.6 to a high of 8 ), but typical values are almost neutral $\mathrm{pH}[88,90]$.

d) Specific conductance measurements indicate very low soluble salt levels in the soils at SRS, which is probably the result of continued leaching by percolating rain water. (Chloride and sulfate leachate levels test relatively low)

e) Soil resistivity measurements taken at depths of 5 feet to 20 feet range from 2300 ohm-cm to 149,000 ohm-cm [90].

These soil characteristics at SRS, which include well drained and excessively drained soils, low total dissolved solids and neutral $\mathrm{pH}$, indicate that the potential for underground corrosion is relatively low. However, underground corrosion of piping at the Savannah River Site is well documented [91]. Soil surveys in the F and H area tank farms have indicated a generally high resistivity with pockets of lower resistance [90, 92]. The possibility of corrosion is low in high resistivity soils, but the soil may be locally corrosive at the lower resistivities. Numerous lateral and vertical changes between sands and clays occur over short distances. This is typical of the coastal plain environment and was observed in the DWPF area [93]. Large variations in soil resistivity provide for a possibility of galvanic corrosion. Galvanic corrosion usually appears when the pipe traverses soils of different composition, and as a result one section of the pipe becomes anodic with respect to another.

There have been several reports of failures of underground piping [61]. Most of these failures occurred due to improper and/or inconsistent application of the outer protective coatings. The lines were most often coated with bitumastic and wrapped with tape. The tape is usually polyethylene and approximately 10 mils thick. Pitting typically occurs when the coating breaks down at local sites (i.e., pinholes or holidays in the protective coating) and moisture from the soil comes in contact with the pipe.

One of three types of loose granular or powdered hydrophobic thermal insulation may have been placed around the coated jackets: Gilsogard ${ }^{\mathrm{TM}}$ (ca. 1965 [34]), Gilsotherm ${ }^{\mathrm{TM}}$ (ca. late 1960's - 1978 [94]) and Gilsulate ${ }^{\mathrm{TM}} 500$ (ca. 1978-present [94]). Drawings confirm that the Type II transfer lines were typically buried in 6 to 8 inches of Gilsotherm $^{\mathrm{TM}}$ or Gilsulate ${ }^{\mathrm{TM}} 500$. It is not known how many of the jackets were placed in Gilsogard $^{\mathrm{TM}}$. However, given the time frame that Gilsogard ${ }^{\mathrm{TM}}$ was included in the specification for thermal insulation and when the waste tanks that are associated with the Type II transfer lines were constructed, it may be assumed that few lines were buried in Gilsogard $^{\mathrm{TM}}$. In general, the insulation materials are hydrophobic and thus prevent water penetration. Therefore, if the insulation was properly placed and the temperature near the 
insulation has been relatively low, minimal corrosion of the exterior of the steel jacket is expected.

However, there have been examples of failures of the carbon steel piping that were buried in these types of insulation. Poor placement of the insulation such that water is allowed to penetrate to the jacket surface is usually the cause of corrosion failure. The attack is usually characterized as pitting over a locally thinned area. Additionally there are concerns that attack beneath the Gilsotherm ${ }^{\mathrm{TM}}$ insulation is more likely than the Gilsulate $500^{\mathrm{TM}}$. Laboratory tests indicate that when the Gilsotherm ${ }^{\mathrm{TM}}$ is heated, the organic material will harden creating cracks in the insulation [94]. Water penetrating into the insulation becomes acidic, and could result is severe corrosion of the carbon steel jacket. Corrosion of several steam lines has been observed where the pipes were buried in Gilsotherm $^{\mathrm{TM}}$ [36]. In the late 1970s, SRS changed the powdered insulation fill to Gilsulate $500^{\mathrm{TM}}$, an inorganic material that does not harden and crack. Since this change occurred, the performance of buried carbon steel piping has improved, although there have been occasional failures (see Section 5.2.3).

While no conclusions are drawn directly from the discussion above, this information is important in understanding the discussions that follow in sections 5.2.1, 5.2.3, 6.2, 6.2.2, and 6.3 .

\subsection{Monitoring and Inspection of Transfer Lines}

\subsection{Monitoring of Transfer Lines for Through-Wall Penetrations}

The transfer line systems, where possible, are monitored to assess leak integrity [95]. A 15 psig air pressure test was developed to detect through-wall penetrations. See Figure 21 for details of an example of a leak detection system that utilizes a leak detection box (LDB). Note that the same test pressure may also be performed via a jacket vent pipe, a modified LDB, or a leak probe sleeve (LPS).). In the example, a portable air compressor delivers air though a portable air delivery system into the LDB via an LDB dip tube. The air pressurizes the LDB, jacket and jacket drain line, and the jacket vent line. If the pressure in the line drops 1 psig within 20 minutes, the line is recorded as having failed. This test is sensitive enough to detect hole diameters of $0.01 "$ ". This test is performed at least every two years for frequently used lines and is required for inactive lines before they can be utilized.

If a loss of pressure is detected, there are two tests utilized to locate the site of the through-wall penetration: a) soap bubble and b) helium leak test [95]. For the first method the ground above the transfer line is wetted with soapy water. The ground is then examined for excessive foaming. If the through-wall penetration is not located by this method, a helium (He) leak test is utilized. For the He-leak test, the gas is introduced into the jacket through the LDB dip tube. Air samples are then extracted from soil boreholes (spaced approximately 10 feet apart along the transfer line) and ventilation exhausts. The air samples are then analyzed with a modified mass spectrometer for He. 


\section{Page 41 of 69}

It should be noted that the jacket pressure testing procedure cannot be performed on some of the transfer lines due to physical configuration. The lines which cannot be pressure tested have been documented [see Asset Information Management (AIM) database]. If the line cannot be pressure tested, an evaluation is performed to examine the risks associated with utilizing the transfer line [96].

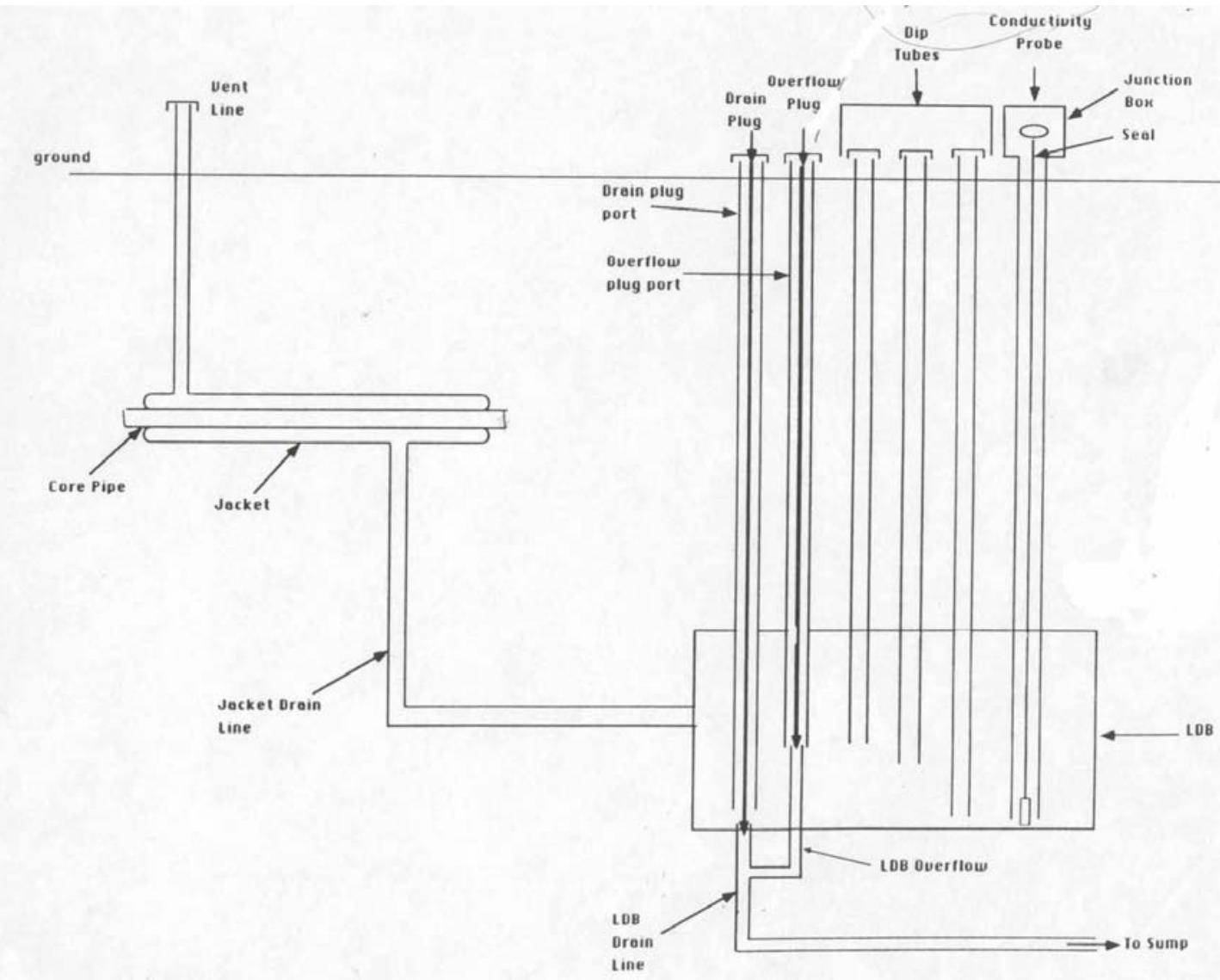

Figure 21. Sketch of transfer line leak detection system.

\subsection{Inspection of Transfer Lines}

There have been relatively few in-service inspections performed on the core and jacket piping for the purpose of determining the amount of degradation. Routine, nondestructive techniques such as ultrasonic testing (UT) are impractical for the transfer line system, since it would require excavating around the lines and may also expose workers to radiation unnecessarily. Typically, when a through-wall penetration is discovered by the pressure test, the pipe is either repaired or replaced. The cases where measurements have been recorded are summarized below. 


\subsubsection{Jackets Associated with FDB-2}

The results of the UT measurements for line \#106 were specifically cited in the DOE transfer line assessment [5]. In 1999, modified leak detection box \#3 (MLDB-3) near diversion box \#2 in F-area (FDB-2) was being replaced [97]. Excavation at the site revealed that a through-wall pit had developed on the carbon steel jacket associated with the transfer line, Line \#106. A UT inspection of the area of the jacket pipe surrounding the hole was performed to determine whether there was sufficient wall thickness to repair the line in-place.

The results of this inspection also raised an additional concern with regard to the seismic evaluation of the underground transfer lines [97]. The calculations had initially assumed that jacket piping thickness was schedule 40 (i.e., 0.237"). However, the measured thickness was considerably less. The seismic evaluation was initially revised assuming a nominal thickness of 0.188 " (i.e., the maximum thickness measured).

For this evaluation a further review of the design drawings was performed. Drawing W235672 contained key information regarding wall thickness of the jacket piping. The drawing indicates that line \#106 is a 3" core pipe with a 4" jacket. The pipe code for the core is P39.020 indicating the line was placed according to Specification 3018. There is also an asterisk next to the 4" jacket directing the reader to a specification note on the drawing. The specification note reads:

"Jackets on process lines shown on this dwg as 4" C.S. are 4.5" OD x 0.156 " wall carbon steel pipe ASTM A53 seamless with "X Tru Coat" underground protection...."

Data from the UT inspection of line \#106 are displayed in Table 11 [98]. Figure 22 shows the location on the jacket where the data was collected. The thickness of the pipe ranged from 0.146 " to 0.188 ". The minimum thickness was located on the extrados of the elbow and the average thickness, excluding measurements taken in the elbow, was 0.162 ". All measurements were above the minimum allowable thickness of 0.137 " [107]. The examination confirmed that corrosion was external and confined to the local spot where the failure occurred. This is an example of a damaged or poorly applied protective coating that induced pitting or localized general corrosion.

The 0.156 " nominal wall thickness shown on the drawing is consistent with the average UT wall thickness measurement. The minimum thickness of 0.146 " also meets the criteria of greater than $87.5 \%$ of the nominal thickness required by Specification 3018 . The measurements demonstrate that after approximately 40 years of service little general corrosion occurs on the exterior surface due to the protective coating. On the other hand, pitting at a local site can occur where the coating breaks down. From a structural stability standpoint, the wall thickness is maintained and this represents excellent performance. However, the leak tightness of the jackets is not assured if only the protective coating covers the jacket. Note that the early piping systems did not have the special protective insulation barrier that the later Type II piping systems have. The 
WSRC-TR-2005-00532

March, 2006

Page 43 of 69

insulation barrier, properly placed, would provide an additional layer of corrosion protection.

Table 11. Wall thickness measurements for Line \#106 (near FDB-2) [98].

\begin{tabular}{|c|c|c|c|c|}
\hline Location & $0^{\circ}$ & $90^{\circ}$ & $180^{\circ}$ & $270^{\circ}$ \\
\hline $\mathrm{A}$ & $\mathrm{N} / \mathrm{A}$ & $0.165^{\prime \prime}$ & $\mathrm{N} / \mathrm{A}$ & N/A \\
\hline $\mathrm{B}$ & N/A & $0.167 "$ & N/A & N/A \\
\hline $\mathrm{C}$ & N/A & $0.159 "$ & $\mathrm{~N} / \mathrm{A}$ & $\mathrm{N} / \mathrm{A}$ \\
\hline $\mathrm{D}$ & $0.148^{\prime \prime}$ & $0.165^{\prime \prime}$ & $0.188^{\prime \prime}$ & $0.154 "$ \\
\hline$E$ & $0.152 ”$ & $0.160 "$ & $0.188^{\prime \prime}$ & $0.157^{\prime \prime}$ \\
\hline $\mathrm{F}$ & N/A & $0.151 "$ & N/A & $\mathrm{N} / \mathrm{A}$ \\
\hline G & $\mathrm{N} / \mathrm{A}$ & $0.146 "$ & N/A & $\mathrm{N} / \mathrm{A}$ \\
\hline $\mathrm{H}$ & N/A & N/A & N/A & N/A \\
\hline I & N/A & $0.153^{\prime \prime}$ & $\mathrm{N} / \mathrm{A}$ & N/A \\
\hline $\mathrm{J}$ & $\mathrm{N} / \mathrm{A}$ & $0.155^{\prime \prime}$ & $\mathrm{N} / \mathrm{A}$ & N/A \\
\hline $\mathrm{K}$ & $\mathrm{N} / \mathrm{A}$ & $0.158^{\prime \prime}$ & $\mathrm{N} / \mathrm{A}$ & N/A \\
\hline $\mathrm{L}$ & N/A & $0.159 ”$ & N/A & N/A \\
\hline
\end{tabular}

N/A - Not Available

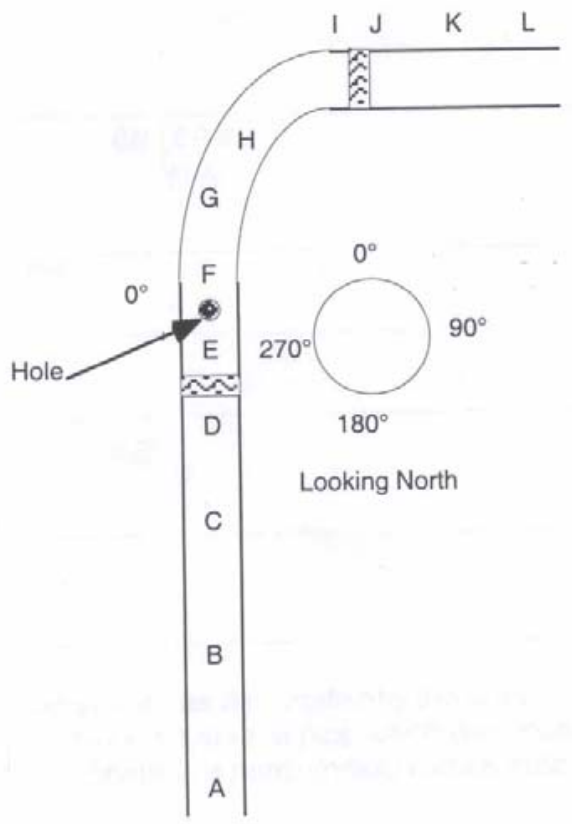

Figure 22. Diagram showing the location of the through-wall penetration and area of UT data collection on Line \#106 (near FDB-2) [98].

Several other process lines near line \#106 also had jackets with a wall thickness of 0.156". In 1980, a failure of the jacket on transfer line \#108 was discovered near the 
concrete wall of FDB-2 [99]. The dimensions of the jacket were the same as those for line \#106. Visual inspection revealed a crack in the weld that attaches line \#108 to the wall of FDB-2. The failure was likely due to a poor weld in combination with surface loading (e.g., heavy cranes). The jacket showed little or no evidence of wall thinning or pitting (see Figure 23). This observation provides further evidence that properly coated lines do not suffer general corrosion and excessive thinning. However, local damage or small flaws in coatings lead to local attack and the formation of small through-wall penetrations.

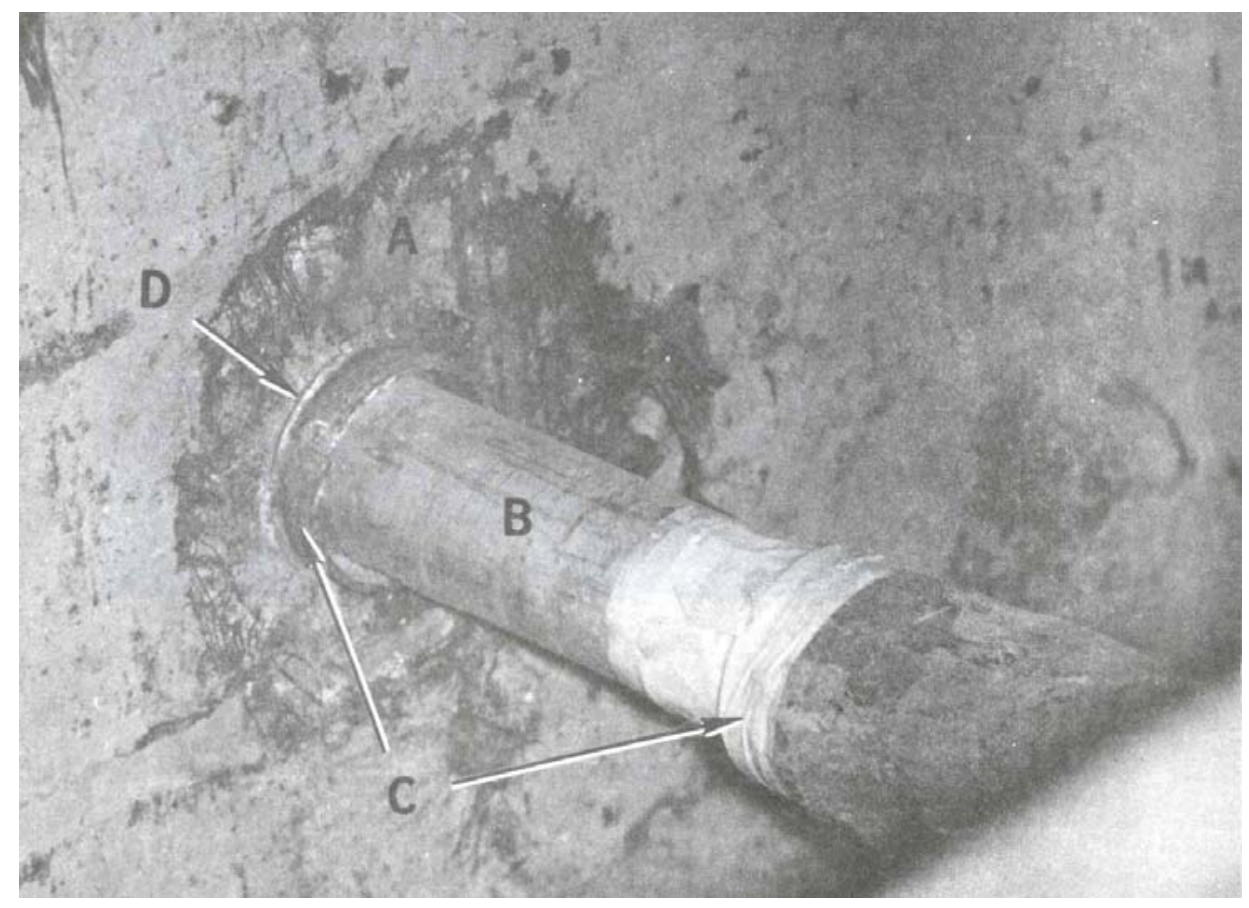

Figure 23. View of FDB-2, Line \#108 with 9-inch section of jacket removed: (a) FDB-2 concrete wall, (b) core pipe, (c) jacket, (d) cracked weld [99].

According to drawing W235672, there are other jackets near FDB-2 that have the same dimensions. These include, but are not necessarily limited to, lines 100, 101, 102, 103, 104,107 and 110 . The nominal thickness of the jacket (0.156") should be utilized in the seismic evaluation. The seismic evaluations have recently been updated to reflect this nominal thickness [100, 106, 109].

\subsubsection{Radioactive Waste Transfer Lines Associated with Tanks 1 through 8}

In 1976, several transfer lines associated with Tank 1 through 8 were replaced [101]. These transfer lines consisted of a carbon steel core pipe and jacket (i.e., Type IIA transfer line), though some of the core pipe elbows were stainless steel. The transfer lines were replaced with 304L stainless steel core pipe with a carbon steel jacket. However, no failures of the Type IIA transfer lines had occurred in 15 years of service. 


\section{Page 45 of 69}

A visual examination and wall thickness measurements were performed on seven sections of the core pipe and one jacket section. The results of these examinations are shown in Table 12. Examples of carbon steel and stainless steel elbows are shown in Figures 24 and 25, respectively. No significant corrosion or reduction in wall thickness was noted on any of the sections, although a small degree of pitting corrosion was observed on the interior of one of the carbon steel elbows. All measured wall thicknesses were greater than $87.5 \%$ of the nominal wall thickness that was required in the specification.

Table 12. Wall Thickness Measurements on Waste Transfer Line Piping Associated with Tanks 1 through 8 [101]

\begin{tabular}{|l|l|c|l|}
\hline Sample Description and Location & Specified Size & $\begin{array}{l}\text { Nominal Wall } \\
\text { Thickness (in.) }\end{array}$ & $\begin{array}{l}\text { Measured Wall } \\
\text { Thickness (in.) }\end{array}$ \\
\hline $\begin{array}{l}\text { Straight carbon steel section of } \\
\text { core pipe between Tanks 1 and 7 }\end{array}$ & 3" Schedule 40 & 0.216 & 0.20 \\
\hline $\begin{array}{l}45^{\circ} \text { carbon steel elbow from core } \\
\text { pipe between Tanks 1 and 7 }\end{array}$ & 3" Schedule 40 & 0.216 & $\begin{array}{l}\text { Pipe }-0.19 \\
\text { Elbow }-0.23\end{array}$ \\
\hline $\begin{array}{l}\text { Stainless steel 45 elbow welded } \\
\text { to carbon steel from core pipe } \\
\text { between Tanks } 1 \text { and 7 }\end{array}$ & 3" Schedule 40 & 0.216 & $\begin{array}{l}\text { Pipe }-0.20 \\
\text { Elbow }-0.19\end{array}$ \\
\hline $\begin{array}{l}45^{\circ} \text { carbon steel elbow from } \\
\text { jacket between Tank 1 and 7 }\end{array}$ & 4" Schedule 40 & 0.237 & 0.21 \\
\hline $\begin{array}{l}90^{\circ} \text { carbon steel elbow from core } \\
\text { pipe between Tanks 2 and 7 }\end{array}$ & 3" Schedule 40 & 0.216 & 0.20 \\
\hline $\begin{array}{l}\text { Straight butt welded carbon steel } \\
\text { section from core pipe between } \\
\text { Tanks 3 and 7 }\end{array}$ & 4" Schedule 40 & 0.237 & 0.20 \\
\hline $\begin{array}{l}90^{\circ} \text { carbon steel elbow from core } \\
\text { pipe between Tanks 5 and 7 }\end{array}$ & 3" Schedule 40 & 0.216 & 0.21 \\
\hline $\begin{array}{l}45^{\circ} \text { stainless steel elbow from } \\
\text { core pipe between Tanks 6 and 7 }\end{array}$ & 3" Schedule 40 & 0.216 & 0.19 \\
\hline
\end{tabular}


WSRC-TR-2005-00532

March, 2006

Page 46 of 69

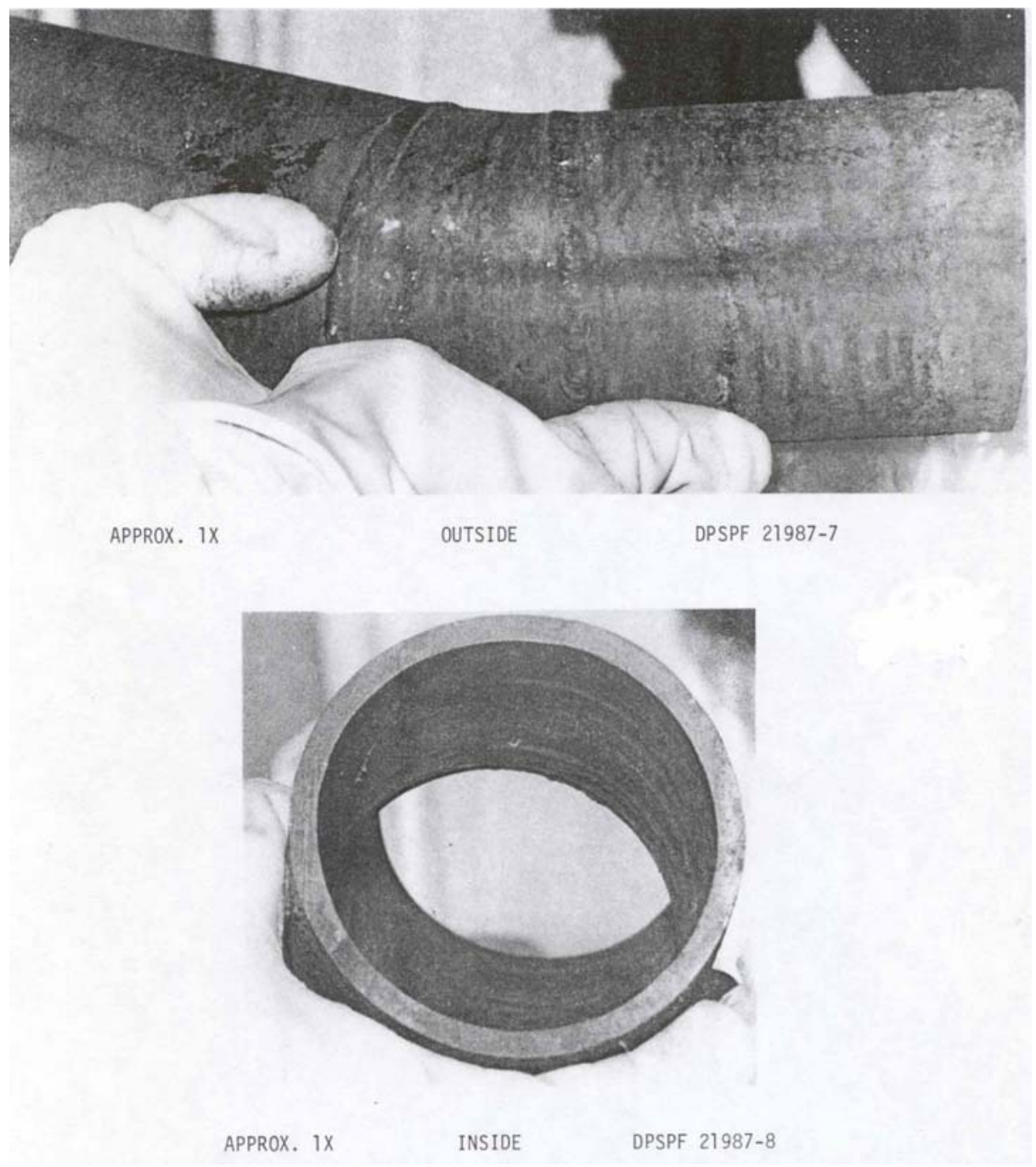

(a)

Figure 24. Carbon steel elbow from core pipe between Tanks 1 and 7: (a) exterior and (b) interior [101]. 


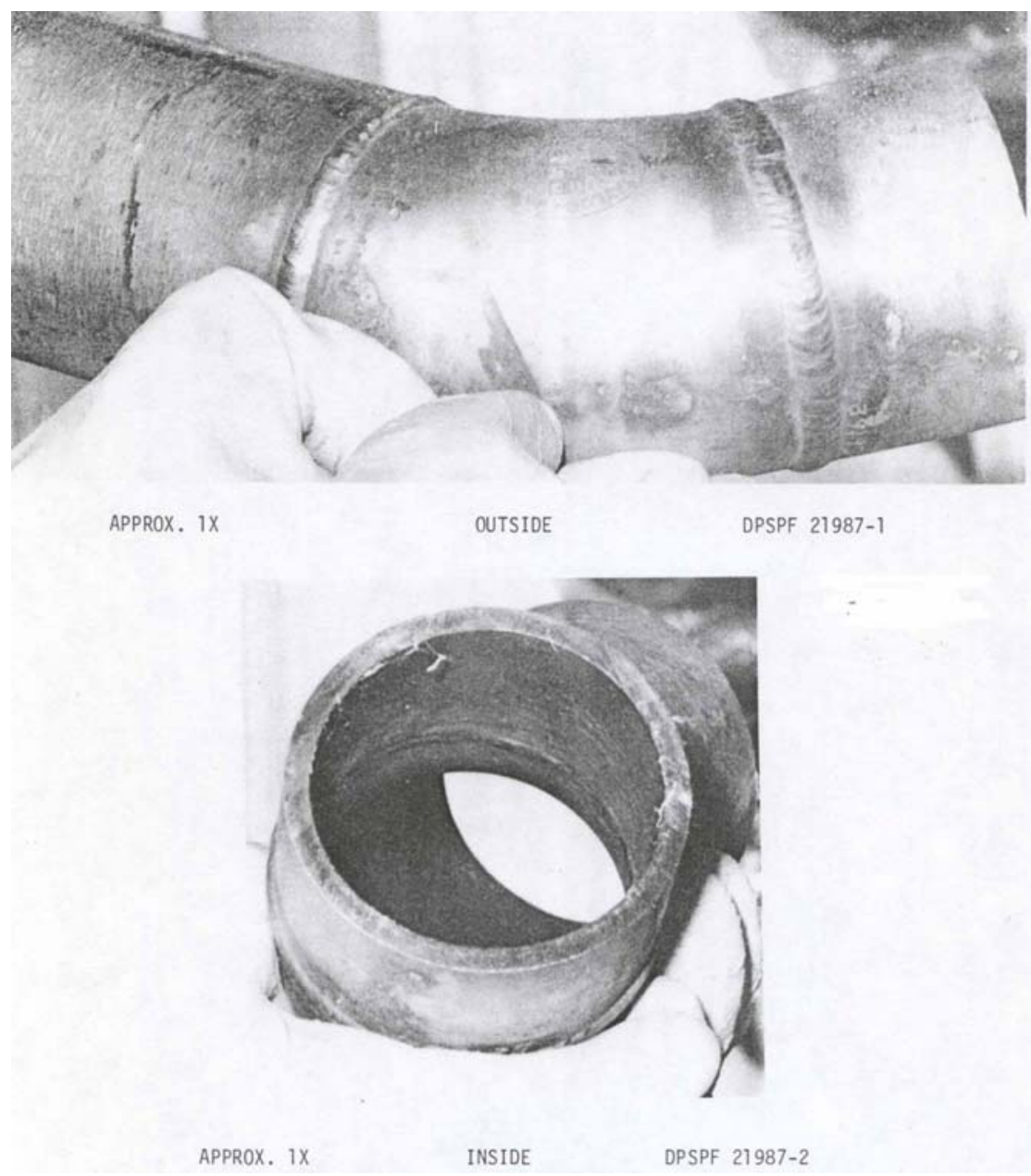

(a)

(b)

Figure 25. Stainless steel elbow from core pipe between Tanks 6 and 7: (a) exterior and (b) interior [101].

The observation that stainless steel elbows were attached to carbon steel pipe raises the issue of galvanic corrosion due to contact between dissimilar metals. Tests performed recently with carbon steel and stainless steel in contact while being exposed to a high level waste simulant indicate that significant corrosion is unlikely [102]. As noted in the material degradation discussion earlier, the erosion resistance of the elbow would be improved with the use of stainless steel. The visual observations and wall thickness measurements indicate that minimal wall loss (corrosion and/or erosion) occurred over an extended time (i.e., 15 years).

\subsubsection{Jacket for Transfer Line \# 1663 (near Tank 50)}

The carbon steel jacket for line \#1663, located near Tank 50, was excavated in 2003 [103]. The pipe is 10" diameter Schedule 20 (nominal wall thickness 0.250"). The pipe had been in service for approximately 20 years and was packed in Gilsulate insulation. Visual examination revealed corrosion on a 30" segment of the jacket exterior and showed evidence of broad shallow pitting with isolated areas having deeper pits (see 
Page 48 of 69

Figure 26). Generally, the wall loss was greater (more frequent and deeper pitting) along the bottom half of the jacket.

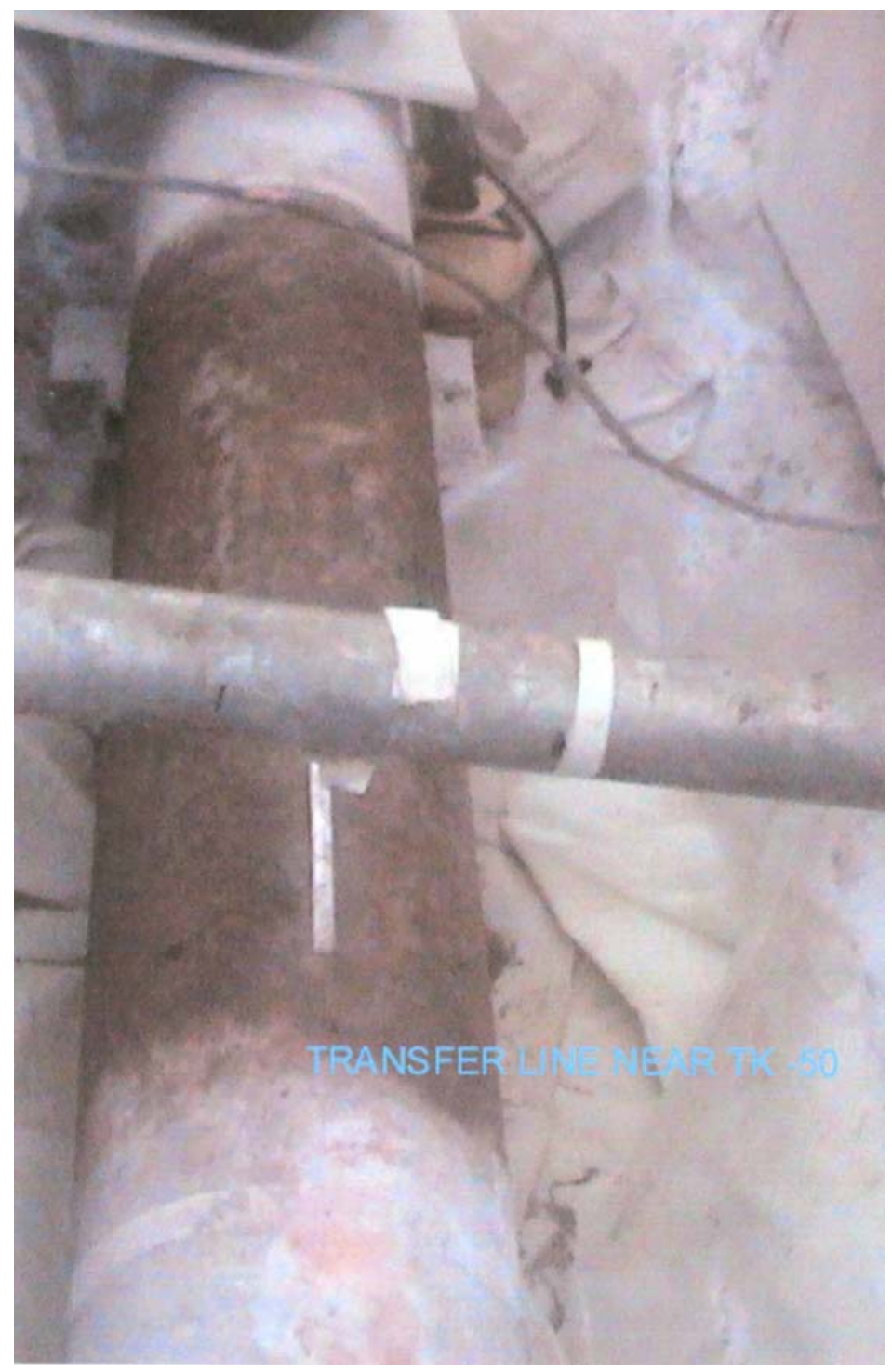

Figure 26. View of Line \#1663 (near Tank 50) that shows corrosion of the exterior of the jacket [103].

Ultrasonic line scans were performed every 45 degrees around the jacket circumference to determine the wall thickness profile. Approximately 12,000 data points were recorded (see Figure 27 for an example of the thickness profile). Examination of all the profile data showed that the average thickness (approximately 0.24 ") is near the nominal thickness. However, significant pitting was identified and the minimum wall thickness at the deepest pit was 0.127 '. 


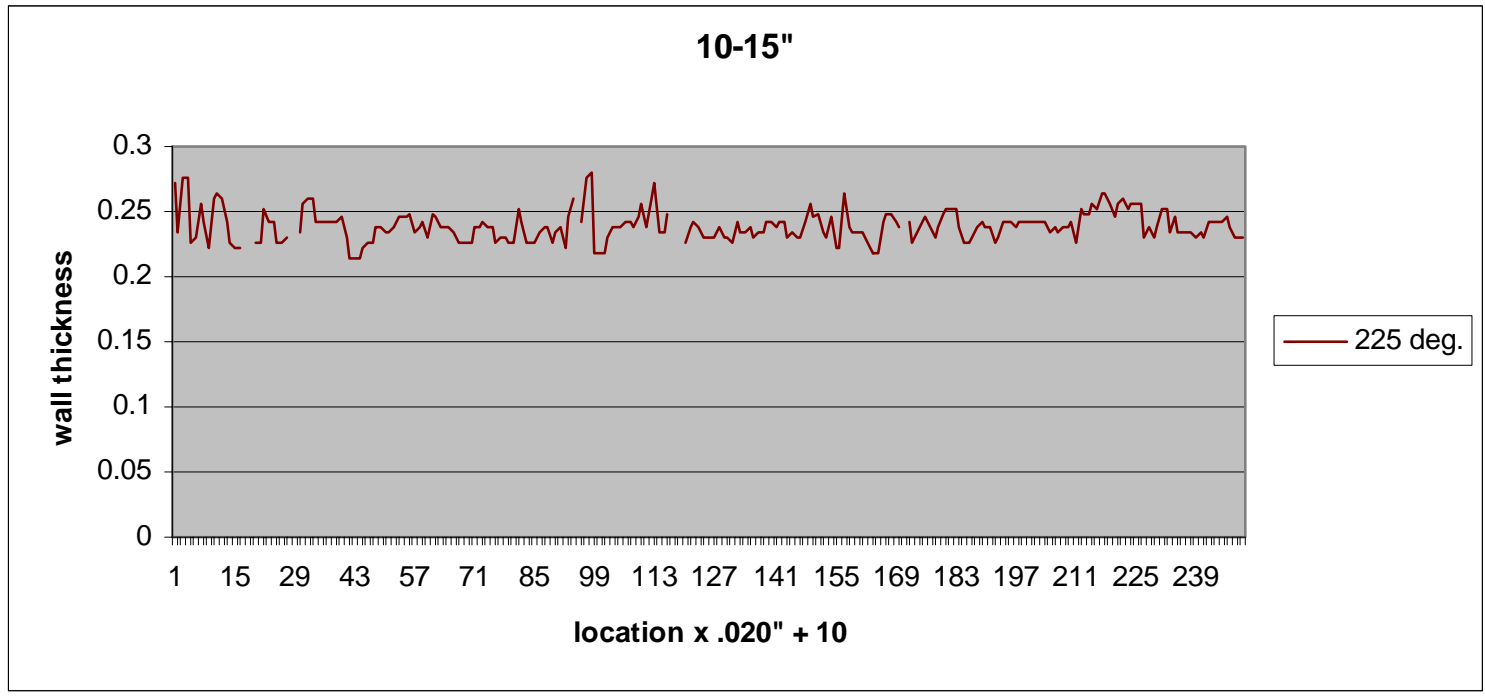

Figure 27. Thickness profile of Line \#1663 (near Tank 50). The location is approximately 10-15” along the corroded area at approximately $225^{\circ}$ from the top of the pipe [103].

The cause of the corrosion was not explained in the UT report. However it is likely that the Gilsulate insulation had been disturbed in this area, thus allowing water intrusion to the pipe. This water would become entrapped at the pipe surface leading to corrosion. Figure 26 also shows that the pipe on either side of the corroded area remains unattacked, again emphasizing the isolated and localized nature of corrosion that occurs on the transfer line jackets.

\subsubsection{Tank 28 Radioactive Waste Transfer Line Jackets}

Recently UT inspections were performed on the aboveground portion of four transfer line jackets near Tank 28 [104]. The dimensions of the jackets were 6" diameter schedule 40 (nominal wall thickness 0.28 "). These transfer line segments were installed in the early 1990s and have been unused since then. The jackets have been unprotected and essentially exposed to ambient conditions. These measurements do not reflect the soil environment, however, they provide information as to whether the initial wall thickness was greater than nominal.

Figures 28 through 31 show the location where the spot UT thickness data was taken on each jacket. The average thickness for the pipes was 0.284 ", while the minimum thickness ranged between 0.244 " to 0.252 ". The minimum thickness was always associated with the extrados of a pipe elbow. The minimum allowable installed thickness is 0.245 " [107]. The majority of the data indicate that the measured wall thickness is well above the minimum allowable installed wall thickness.

One spot measurement on the jacket for line \#1216 was just below the minimum allowable installed thickness (0.244" vs. 0.245 "). However, this result does not necessarily mean that the jacket did not meet the requirements of the specification at the 
Page 50 of 69

time of installation. The accuracy of the UT measurement is typically $\pm 1 \%$ of the wall thickness \pm 0.001 inches. Given these tolerances, the actual wall thickness could be anywhere between 0.241 " and 0.247 '. Thus, the pipe may or may not have actually been within the specification. It is also worth noting that if the measurement is accurate, it is possible that less than 1 mil of corrosion has occurred after 15 years of exposure to the atmosphere. This corrosion rate is extremely slow even in atmospheric conditions.

These jackets will be shielded with lead and covered with insulation in the near future. Installation of the exterior insulation under current quality control practices will ensure that little or no further degradation of the carbon steel occurs during service. The ambient environment is expected to be less aggressive than the soil. Therefore, no additional actions are recommended for this situation.

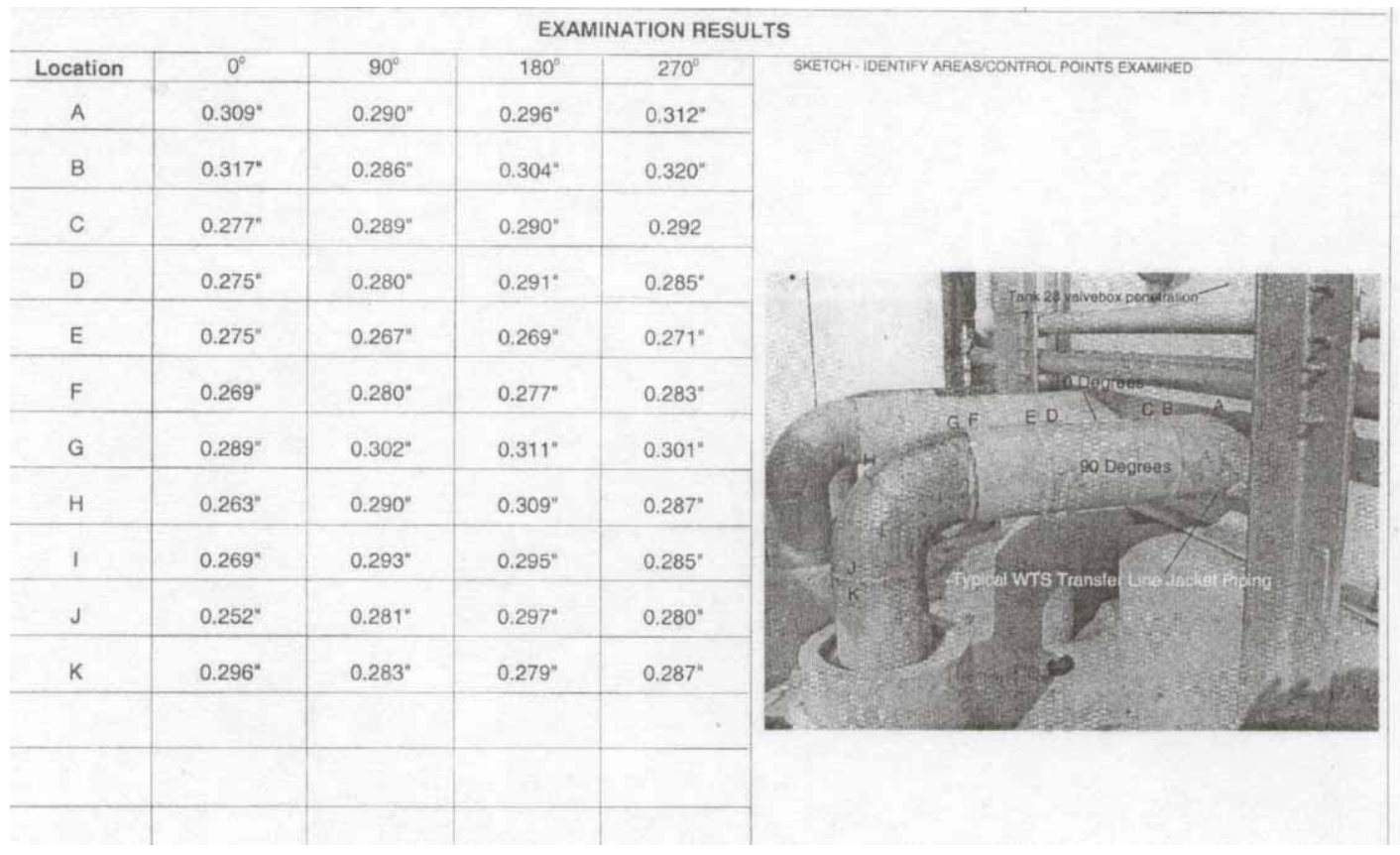

Figure 28. UT data for Line \#1211 jacket (near Tank 28) [104]. 
WSRC-TR-2005-00532

March, 2006

Page 51 of 69

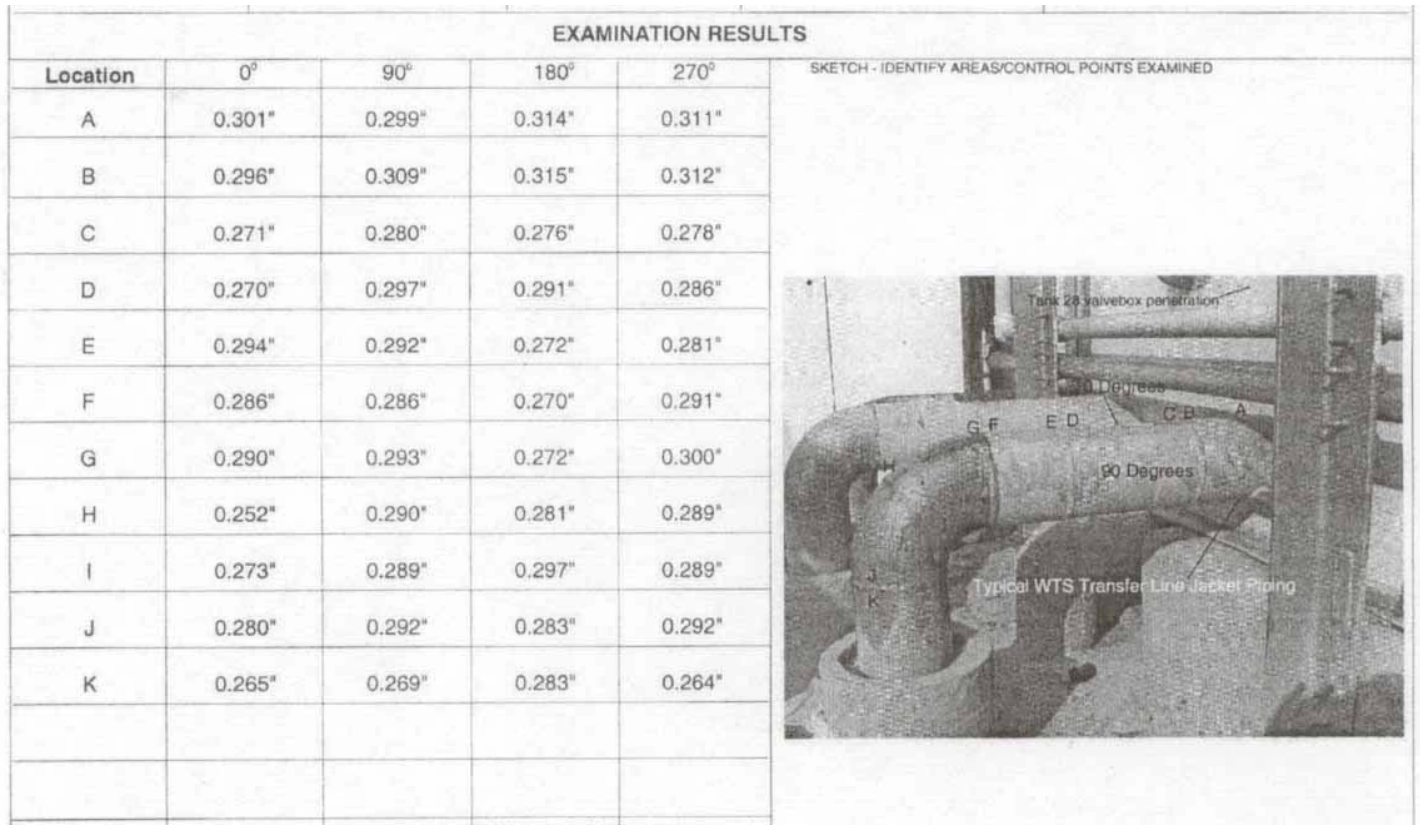

Figure 29. UT data for Line \# 1218 jacket (near Tank 28) [104].

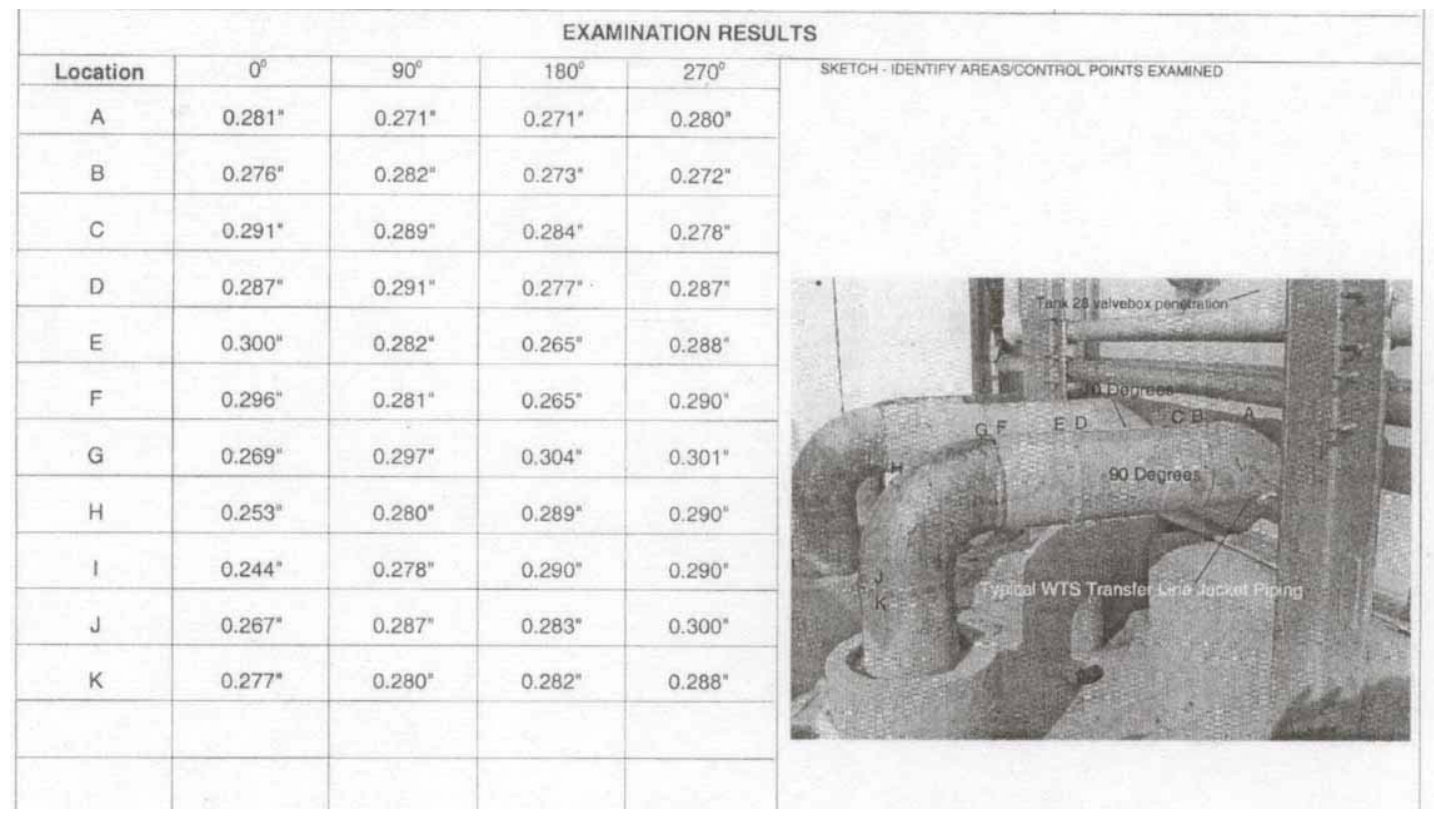

Figure 30. UT data for Line \# 1216 jacket (near Tank 28) [104]. 
WSRC-TR-2005-00532

March, 2006

Page 52 of 69

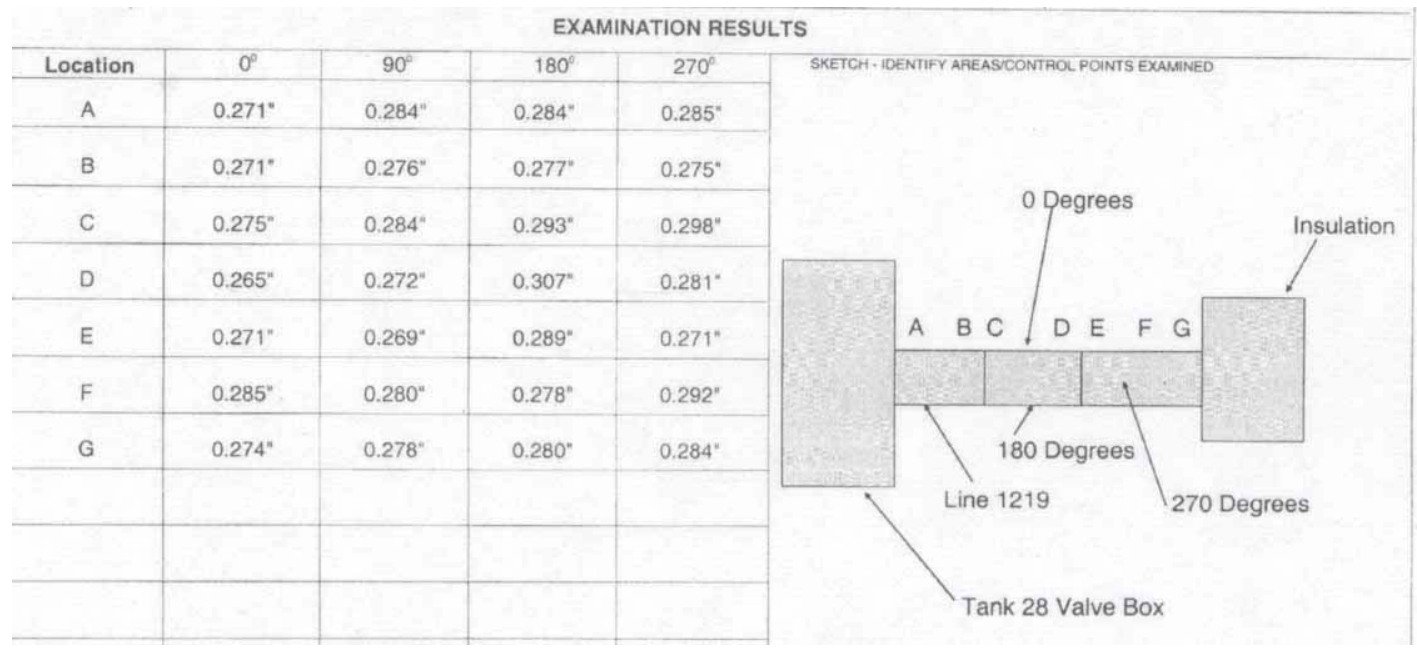

Figure 31. UT data for Line \#1209 jacket (near Tank 28) [104].

\subsection{Life Estimation Calculations and Fitness-For-Service Evaluation}

The design codes and standards for pressurized equipment provide rules for the design, fabrication, inspection, and testing of new piping systems. These codes do not address in-service degradation. Fitness-For-Service evaluations are quantitative engineering analyses which are performed to demonstrate the structural integrity of an in-service component that contains a flaw. API-579 provides guidance for performing these evaluations [105]. It is significant to realize that these evaluations are primarily performed for components that have 1) experienced some degradation, and 2) degradation is part through-wall and a decision to run, repair, or replace is needed. In most of the cases cited in the previous section, corrosion was either insignificant or small localized penetrations had occurred. The exception was the jacket for Line \#1663, which showed pitting and localized thinning, but no holes.

\subsection{Life Estimation Calculations for Stainless Steel Core Pipe}

Rather than performing a Fitness-For-Service evaluation for the core pipe, an estimate of the remaining useful life for the core piping will be made. Normal service conditions will be considered, so only general corrosion and erosion apply. Off-normal service conditions which result in stress corrosion cracking, pitting, or microbiologically induced corrosion must be controlled by design (e.g., chloride limits on tape used to wrap lines) or administratively (e.g., minimize exposure to well water).

\subsubsection{General Corrosion}

Step 1. Determine the minimum required wall thickness $\left(t_{\min }\right)$ for a 3 " core pipe.

To evaluate the remaining life of the waste transfer lines the minimum required wall thickness of the line must be determined. Two load cases define the stress state in the 


\section{Page 53 of 69}

piping: pressure and seismic loads. The pressure load produces a hoop stress in the piping component. There are two pressure load cases that require evaluation for determining the controlling minimum wall condition. They include the design pressure and a hypothetical accident condition. The design pressure is defined by the ASME B31.3 code, while the pressure load case accident condition is based on a bounding hydrogen explosion in the piping system. However, neither pressure load case controlled the minimum wall thickness of the piping. Bending moments in the piping system produced by the seismic loading on the piping is the controlling load for minimum wall thickness.

To determine the minimum required wall thicknesses for the seismic bending moments, the maximum seismic load was used to calculate the minimum required section modulus that would produce the maximum allowable stress in the piping system. The minimum required wall thickness is the pipe wall thickness required to provide the minimum required section modulus. An example calculation is presented in Appendix B.

The waste transfer core piping was evaluated for both 3 inch diameter schedule 10 and 3 inch diameter schedule 40 wall thicknesses. Line \#3754 is located in the F-Area tank farm near valve boxes 1-4 and was selected as the bounding case for the schedule 10 piping. The seismic bending moment for the schedule 10 piping was 33,600 in-lb [106]. The calculated minimum required wall thickness was 0.075 ". Line \#1252A/\#1660/\#3056 is located in H-Area near the Tank 49 valve box and was selected as the bounding case for the Schedule 40 piping (Note: This is a single line with 3 identification numbers). The seismic bending moment for the schedule 40 piping was 78,600 in-lb [100]. The calculated minimum required wall thickness was $0.193 "$.

Step 2. Determine the minimum wall thickness of the pipe $(\mathrm{t})$.

The permitted variation in wall thickness for the piping is $12.5 \%$ less than nominal in accordance with ASTM requirements [107]. For the bounding calculation it will be assumed that the wall thickness of the pipe is at this minimum value. Two pipe schedules were utilized for the core pipe: Schedule 10 and Schedule 40. Given that the nominal thickness for a 3" Schedule 10 pipe is 0.12 ", the minimum pipe wall thickness is 0.105 ". For 3" Schedule 40 pipe, the nominal thickness is 0.237 ", and thus the minimum pipe wall thickness is 0.207 ”.

Step 3. Determine the corrosion allowance for the pipe.

The corrosion allowance $\left(\mathrm{C}_{\mathrm{A}}\right)$ is determined by subtracting the minimum allowable wall thickness $\left(t_{\min }\right)$ based on stress calculations from the minimum wall thickness $(t)$ existing at manufacture. For the Schedule 10 pipe, the corrosion allowance is 0.030 ", whereas for the schedule 40 pipe the corrosion allowance is 0.014 ". 
Step 4. Calculate the expected life of the pipe.

The general corrosion rate $\left(\mathrm{C}_{\mathrm{R}}\right)$ for stainless steel exposed to a high level waste simulant was $0.000078 \% / y r$ [42]. The expected life of the pipe is calculated by dividing the corrosion allowance for the pipe by the general corrosion rate. The expected life for the Schedule 10 piping is approximately 385 years. Given that Schedule 10 piping has been installed for at most 20 years, the piping has approximately 365 years of remaining life. If a pipe were inspected at this time, no practical difference between the measured wall thickness and the initial wall thickness would be expected (i.e., 20 years x 0.000078 inches per year $=0.0016$ inches of wall loss). This small amount of wall loss would not be detectable. The expected life for the Schedule 40 piping is approximately 180 years. Given that the Schedule 40 piping has been installed for at most 50 years, the piping has approximately 130 years of remaining life. If a pipe was inspected at this time, no practical difference between the current wall thickness and the initial wall thickness would be expected (i.e., 50 years x 0.000078 inches per year $=0.0039$ inches of wall loss).

\subsubsection{Erosion/Corrosion}

Core pipes utilized to transport significant quantities of solids could potentially erode and have a shorter service life. Life expectancy calculations that considered a contribution due to erosion were performed. The corrosion allowance assumed for general corrosion will be utilized for these calculations. As mentioned above the most vulnerable areas would be at an elbow, which also happens to be where the minimum wall thickness is expected. Two environments will be considered: 1) Sludge Slurry and 2) DWPF Recycle. A generic assumption will be made that the transfer path may include piping that is either Schedule 10 or Schedule 40. Life expectancies for both cases will be considered.

Step 1. Determine usage factors.

Sludge slurry transfers and DWPF Recycle transfers occur periodically. Therefore, the elbow is not constantly exposed to a flowing condition. Three bounding cases were considered:

a) Sludge slurry transfer during bulk waste removal;

b) Sludge slurry transfer from Tank 40 to the low point pump pit;

c) DWPF Recycle to the tank farm.

An estimate of the total annual usage time was determined for each case. Inputs and assumptions for each case are also discussed below.

a) Sludge slurry transfer during bulk waste removal

Input: The transfer line immediately adjacent to the tank where bulk sludge removal operations are being performed will likely only see one series of 4 to 5 sludge slurry 
transfers during their lifetime. However, the transfer line that travel from HDB-7 to Tank 51, will experience all the transfers that occur during bulk sludge removal operations. Therefore, these lines will be utilized as a bounding case for sludge slurry transfer during bulk waste removal. The line from HDB-7 to Tank 51 is composed of three segments: \#3060, \#16052, and \#16011.

Input: Bulk sludge removal from Tank 11 was recently completed [108]. During the past year, 5 transfers were performed each lasting approximately 48 hours. Therefore, these transfer lines were exposed to 10 days of a flowing environment over the past year. The annual usage factor for erosion is $10 / 365$ or 0.027 , while for general corrosion the annual usage factor is 0.973 .

Assumption: It will be assumed that Tank 51 will receive a sludge batch every year.

Assumption: The calculation assumes that sludge transfers continue on until the minimum required wall thickness is achieved. Schedules indicate however that sludge removal operations are expected to be complete within the next 30 years. This assumption will allow us to assess the margin on wall thickness given the projected schedule.

The annual usage factor for erosion of the lines in this transfer path is therefore 0.027 , while for general corrosion the annual usage factor is 0.973 .

b) Sludge slurry transfer from Tank 40 to the low point pump pit.

Input: The transfer path from Tank 40 to the low point pump pit includes line segments: \#16312, \#16104, and \#SDP2.

Input: Transfers occur approximately once every eight days. This converts to 46 transfers per year.

Input: Each transfer is approximately 7000 gallons.

Input: The flow rate is approximately 100 gallons per minute.

Assumption: The calculation assumes that sludge transfers continue on until the minimum required wall thickness is achieved. Schedules indicate however that sludge removal operations are expected to be complete within the next 30 years. This assumption will allow us to assess the margin on wall thickness given the projected schedule.

Given the volume per transfer and the flow rate, each transfer will last approximately 70 minutes. Thus, the lines in this transfer path will be exposed to continuous flow for approximately 3220 minutes or 2.23 days per year. The annual usage factor for erosion of the lines in this transfer path is therefore 0.006 , while for general corrosion the annual usage factor is 0.994 . 
c) DWPF Recycle to the Tank Farm.

Input: The current transfer path starts at the low point pump pit and travels to HDB-5 via HDB-8. After HDB-5, the stream may be sent to one of four Type IV tanks (i.e., 21-24). The line segments that will be exposed to this stream the most are: \# RCZ20 and \#RCZ275. These two segments travel between the low point pump pit and HDB-5.

Input: DWPF recycle transfers occur once or twice per week. For conservatism, it will be assumed that they occur twice per week.

Input: The transfers are relatively small (i.e., 10,000 gallons or less).

Assumption: The velocity for this stream will be assumed to be $7.3 \mathrm{ft} / \mathrm{s}$ or $160 \mathrm{gpm}$. This flow rate is the maximum that can be achieved by a pump.

Given a 10,000 gallon transfer and a 160 gallon per minute flow rate, a single transfer would take approximately 1 hour. Given two transfers per week there are a total of 104 transfers per year. Therefore, it is estimated that these lines are exposed to a flowing stream for approximately 104 hours per year or 4.3 days per year. The annual usage factor for erosion is $4.3 / 365$ or 0.012 , while for general corrosion the usage factor is 0.988 .

Step 2. Calculate the expected life of the pipe.

The expected life can be determined from the following equation.

$$
\tau=\mathrm{C}_{\mathrm{A}} /\left(\mathrm{E}_{\mathrm{R}} * \mathrm{U}_{\mathrm{E}}+\mathrm{C}_{\mathrm{R}} * \mathrm{U}_{\mathrm{C}}\right)
$$

Where,

$\tau \quad=\quad$ Life Expectancy, yrs

$\mathrm{C}_{\mathrm{A}}=$ Corrosion Allowance, inches

$\mathrm{E}_{\mathrm{R}}=$ Erosion Rate, inches/yr

$\mathrm{U}_{\mathrm{E}}=$ Usage Factor for Erosion

$\mathrm{C}_{\mathrm{R}}=$ Corrosion Rate, inches $/ \mathrm{yr}$

$\mathrm{U}_{\mathrm{C}}=$ Usage Factor for Corrosion

Example Calculation: 3" Schedule 10 pipe exposed to sludge slurry from HDB-7 to Tank 51. 
Page 57 of 69

Inputs:

$\mathrm{C}_{\mathrm{A}}=0.030$ "

$\mathrm{E}_{\mathrm{R}}=0.0004 \% / \mathrm{yr}[72]$

$\mathrm{U}_{\mathrm{E}}=0.027$

$\mathrm{C}_{\mathrm{R}}=0.000078 \% / \mathrm{yr}$

$\mathrm{U}_{\mathrm{C}}=0.973$

$\tau=(0.030$ inches $) /(0.0004$ inches $/ \mathrm{yr} * 0.027+0.000078$ inches $/ \mathrm{yr} * 0.973)$

$=346$ years

Insertion of these values into Equation 1 gives an expected life, $\tau$, of approximately 346 years. Table 13 summarizes the expected life for both pipe schedules for the three cases. The calculations for the remaining cases are shown in Appendix C. These expected life times are not significantly different from general corrosion alone and therefore indicate that general corrosion is the dominant wall thinning mechanism. The life expectancies are also significantly longer than 30 years of usage that the current waste removal plans estimate.

Table 13. Life Expectancy of Stainless Steel Core Pipe Considering Erosion Due to Sludge Slurry and DWPF Recycle Wastes

\begin{tabular}{|l|c|c|}
\hline & 3" Schedule 10 Pipe & 3" Schedule 40 Pipe \\
\hline $\begin{array}{l}\text { Sludge Slurry from HDB-7 } \\
\text { to Tank 51 }\end{array}$ & 346 years & 161 years \\
\hline $\begin{array}{l}\text { Sludge Slurry from Tank 40 } \\
\text { to Low Point Pump Pit }\end{array}$ & 375 years & 175 years \\
\hline $\begin{array}{l}\text { DWPF Recycle from Low } \\
\text { Point Pump Pit to HDB-5 }\end{array}$ & 378 years & 176 years \\
\hline
\end{tabular}

\subsection{Life Estimation Calculations for Carbon Steel Jacket}

Both remaining useful life and Fitness-For-Service calculations will be performed for the jacket surrounding Line \#1663. This line will be considered representative of the carbon steel jackets on site. Some slight differences in remaining useful life will be due to the diameter of the carbon steel jacket. Jacket diameters range between 4 and 10 inches typically. However, the pipe schedule was specified at design so that the wall thickness was close to 0.25 ". For example, 4" Schedule 40 piping has a wall thickness of 0.237 ", while 10 " Schedule 20 piping has a wall thickness of 0.25 ". This difference in wall thickness is within the error of these calculations.

Data from the Line \#1663 jacket will be used to estimate the remaining useful life of carbon steel jackets. Two mechanisms were considered: general corrosion and pitting corrosion. 
WSRC-TR-2005-00532

March, 2006

Page 58 of 69

\subsubsection{General Corrosion}

Step 1. Determine the minimum allowable wall thickness.

The combination of the pitting corrosion in a thinned area and the bounding seismic loads provide a controlling location to provide a lower bound estimate of the remaining life of the jacket piping. The seismic bending moment for the $10 \mathrm{inch}$, schedule 20 piping was 33,600 in-lb [109]. The calculated minimum required wall thickness was 0.154 ”.

At a wall thickness less than $t_{\text {min }}$, the piping may be vulnerable to loss of structural stability during a design basis seismic event. The remaining useful life can be calculated with Equation 2.

$\tau=\left(\mathrm{t}-\mathrm{t}_{\min }\right) / \mathrm{CR}$

Where,

$\tau=$ life expectancy, yr

$\mathrm{t}=$ average measured wall thickness $=0.24$ inches

$\mathrm{t}_{\min }=$ minimum required wall thickness $=0.154$ inches

$\mathrm{C}_{\mathrm{R}}=$ corrosion rate, inches $/ \mathrm{yr}$

The estimated corrosion rate is calculated from Equation 3.

$\mathrm{C}_{\mathrm{R}}=\left(\mathrm{t}_{\mathrm{nom}}-\mathrm{t}\right) / \tau_{\mathrm{s}}$

Where,

$\mathrm{t}_{\text {nom }}=$ initial nominal wall thickness of pipe $=0.25$ inches

$\mathrm{t}=$ average measured wall thickness $=0.24$ inches

$\tau_{\mathrm{s}}=$ time in service $=20$ years

Note that for this calculation it will be assumed that general corrosion initiated at time zero and has progressed in a linear fashion with respect to time. The general corrosion rate estimated from Equation 3 is 0.0005 inches per year. Substituting this rate into Equation 2, the remaining useful life is approximately 172 years. This time does not represent a time to through-wall failure, but rather the time until the piping cannot be credited with being able to survive a design basis seismic event.

\subsubsection{Pitting Corrosion}

Pitting corrosion will initially result in a through-wall penetration. The development of a through-wall pit would be detected by the air pressure test in most cases. The time for a pit to penetrate through-wall was calculated. The case of pitting corrosion in a locally thinned area has been treated previously [110] and a similar approach will be utilized for the jacket. It should be noted that the ultrasonic measurements were taken on a line. Thus, in utilizing this data the assumption is made that the minimum depths represent the bottom of a pit and not the side of a pit. Ideally these pit depths would have been 
Page 59 of 69

measured over a given surface area such that depths and nearest neighbor pits could be more accurately determined.

Step 1. Determine the pitting factor $(\mathrm{PF})$.

The PF is determined from the following formula:

$\mathrm{PF}=$ Maximum Pit Depth/Depth of General Corrosion

The minimum wall thickness for the jacket was 0.127 ". Given the average wall thickness of 0.24", the Maximum Pit Depth was 0.113". Assuming that the jacket was originally the nominal thickness of 0.25 ", the Depth of General corrosion was 0.01 " (Note: several of the wall thickness measurements were well above nominal). Thus, the PF was 11.3.

Step 2. Determine the constant $\mathrm{K}$ for the pitting equation.

Pit depth has been shown to increase with time in a parabolic fashion [111] according to the following equation:

Maximum Pit Depth $=\mathrm{K} \tau_{\mathrm{s}}{ }^{1 / 2}$

where $\tau_{\mathrm{s}}$ is the time in service. The jacket had been in service for approximately 20 years. Thus,

$\mathrm{K}=(0.113 ") /(20 \text { years })^{1 / 2}=0.0253 " / \mathrm{yr}^{1 / 2}$

Step 3. Determine the total penetration as a function of time, $\tau_{\mathrm{s}}$.

Total penetration $\left(t_{p}\right)$ through the jacket wall is determined by the following equation:

$\mathrm{t}_{\mathrm{p}}=\left[(\mathrm{PF}+1) \mathrm{K} \tau_{\mathrm{s}}^{1 / 2}\right] / \mathrm{PF}$

$\mathrm{t}_{\mathrm{p}}=\left[12.3 * 0.0253 " / \mathrm{yr}^{1 / 2} \tau_{\mathrm{s}}^{1 / 2}\right] / 11.3=0.0275^{\prime \prime} / \mathrm{yr}^{1 / 2} \tau_{\mathrm{s}}^{1 / 2}$

Step 4. Determine the time to penetrate through-wall.

The equation from Step 3 can be rearranged such that $\tau_{\mathrm{s}}$ becomes the time to penetrate through the wall.

$\tau_{\mathrm{s}}=\left(\mathrm{t}_{\mathrm{p}} / 0.0275^{\prime} / \mathrm{yr}^{1 / 2}\right)^{2}$

Assuming that the jacket was initially the nominal thickness of 0.25 ", the time to penetrate through-wall is approximately 80 years.

For comparison purposes, the time to failure for a jacket with a thinner wall was determined (e.g., Line \#106). Substituting the nominal wall thickness of 0.156 " into 


\section{Page 60 of 69}

Equation 5, the time to penetrate through-wall was calculated to be approximately 32 years. Line \#106 had been in service for approximately 40 years when the penetration was discovered in 1999.

Another useful comparison is to use Equation 5 to determine the life expectancy of other underground carbon steel piping such as the transfer line jacket drain lines. During 1989 through 1991, 147 of the 180 carbon steel jackets were pressure tested [1]. Through-wall penetrations were discovered in 22 of the lines and test failures were due to external corrosion failures of jacket vents, jacket drain piping or dip tubes for the leak detection box. These lines were coated and buried directly in the soil. This represents an increase in the number of failures at approximately 15 to 20 years after the lines were placed inservice. The drain lines are 1" Schedule 40 carbon steel pipe. Substituting the nominal wall thickness of 0.133 " into Equation 5, the time to penetrate through-wall is calculated to be approximately 23 years. Based on the two comparisons, Equation 5 appears to provide a reasonable estimate for the service life of the underground carbon steel piping.

Step 5. Determine the remaining useful life.

The inspection was performed in 2003 when Line \#1663 was approximately 20 years old. Thus, a through-wall pit would not be expected to develop for another 60 years.

However, this estimate assumes the steel jacket continues to corrode at the present rate. If the thermal insulation was properly placed around the jacket when this line was returned to service, the corrosion rate may slow significantly and the jacket would remain in essentially the present condition. Therefore, this calculation may be more applicable to a similar pipe that is undergoing corrosion.

The carbon steel jackets in the transfer line systems are likely to suffer further pitting attack at local thin areas beneath insulation or at holidays in a coating due to improper placement of thermal insulation or poor coating application. The 80 year lifetime estimation is supported by the observation that very few failures of transfer line jackets have occurred previously. Thus, the 80 year life expectancy can be utilized to estimate approximately when the transfer line system jackets as a whole may begin to see a significant increase in failure rate. Most of the transfer lines have been in-service for approximately 20 to 50 years. Thus, the remaining life of the jackets is estimated to be 30 to 60 years (2035 to 2065). Due to the statistical nature of pitting some jackets may fail earlier, but it is expected that a significant increase in the number of jacket pressure test failures will be observed after this time.

\subsection{Fitness-For-Service for Carbon Steel Jacket}

Section 6 of API 579 was utilized to assess the pitting that occurred on line \# 1663. A Level 1 Evaluation was performed. Details of the calculation are shown below.

Step 1. Determine the Future Corrosion Allowance (FCA). 
The FCA is calculated by multiplying the anticipated general corrosion rate by the intended future operating period. The anticipated general corrosion rate was determined to be 0.0005 inches/year (see Section 6.2.1.1). For these calculations it will be assumed that the line will be functional until the first penetration. The first penetration was estimated to occur in approximately 60 years. Therefore, the FCA is 0.030 ".

Step 2. Determine initial input parameters

D $\quad=$ Inner pipe diameter, inches $=10.25$ inches

$\mathrm{t}=$ Current thickness in the vicinity of the pitting damage, inches $=0.24$ inches

$\mathrm{RSF}_{\mathrm{a}}=$ Allowable remaining strength factor from Section 2 of API $579=0.9$

$\mathrm{t}_{\min }=$ Minimum required wall thickness (See Appendix B) $=0.154$ inches

Step 3. Determine the Pit-couple parameters.

12 pit couples were measured at various locations on the 30 " section of pipe. The depth $(\mathrm{w})$, diameter $(\mathrm{d})$, and the pitch $(\mathrm{P})$ between the two nearest neighbor pits were determined. The following definitions were utilized.

\begin{tabular}{|c|c|c|}
\hline $\mathrm{W}_{\mathrm{i}, \mathrm{k}}$ & $=$ & depth of pit $\mathrm{i}$ in the pit couple $\mathrm{k}$ \\
\hline $\mathrm{W}_{\mathrm{j}, \mathrm{k}}$ & $=$ & depth of pit $\mathrm{j}$ in the pit couple $\mathrm{k}$ \\
\hline $\mathrm{d}_{\mathrm{i}, \mathrm{k}}$ & $=$ & diameter of pit $\mathrm{i}$ in the pit couple $\mathrm{k}$ \\
\hline$d_{j, k}$ & $=$ & diameter of pit $\mathrm{j}$ in the pit couple $\mathrm{k}$ \\
\hline $\mathrm{P}_{\mathrm{k}}$ & $=$ & Pit couple spacing in pit couple $\mathrm{k}$ \\
\hline wbar $_{\mathrm{i}, \mathrm{k}}$ & $=$ & $\mathrm{w}_{\mathrm{i}, \mathrm{k}}-\left(\mathrm{t}-\mathrm{FCA}-\mathrm{t}_{\min }\right)=\mathrm{w}_{\mathrm{i}, \mathrm{k}}-0.056 "$ \\
\hline $\operatorname{wbar}_{\mathrm{j}, \mathrm{k}}$ & $=$ & $\mathrm{w}_{\mathrm{j}, \mathrm{k}}-\left(\mathrm{t}-\mathrm{FCA}-\mathrm{t}_{\mathrm{min}}\right)=\mathrm{w}_{\mathrm{j}, \mathrm{k}}-0.056^{\prime \prime}$ \\
\hline wbar $_{\text {avg }, \mathrm{k}}$ & $=$ & $\left(\right.$ wbar $\left._{i, k}+w \operatorname{war}_{j, k}\right) / 2$ \\
\hline $\mathrm{d}_{\mathrm{avg}, \mathrm{k}}$ & $=$ & $\left(\mathrm{d}_{\mathrm{i}, \mathrm{k}}+\mathrm{d}_{\mathrm{j}, \mathrm{k}}\right) / 2$ \\
\hline
\end{tabular}

Table 14. Pit-couple Data from Line \#1663 (near Tank 50)

\begin{tabular}{|c|c|c|c|c|c|c|c|c|c|}
\hline Pit Couple & $\mathrm{w}_{\mathrm{i}, \mathrm{k}}$ (inches) & wbar $_{i, k}$ (inches) & $\mathrm{d}_{\mathrm{i}, \mathrm{k}}$ (inches) & $\mathrm{w}_{\mathrm{j}, \mathrm{k}}$ (inches) & wbar $_{\mathrm{j}, \mathrm{k}}$ (inches) & $d_{j, k}$ (inches) & $P_{k}$ (inches) & wbar $_{\text {avg,k }}$ (inches) & $d_{a v g, k}$ (inches) \\
\hline 1 & 0.02 & -0.036 & $\begin{array}{r}0.2 \\
\end{array}$ & 0.015 & -0.041 & 0.18 & 0.18 & -0.0385 & 0.19 \\
\hline 2 & 0.03 & -0.026 & 0.24 & 0.01 & -0.046 & 0.1 & 0.22 & -0.036 & 0.17 \\
\hline 3 & 0.015 & -0.041 & 0.12 & 0.015 & -0.041 & 0.1 & 0.16 & -0.041 & 0.11 \\
\hline 4 & 0.01 & -0.046 & 0.14 & 0.015 & -0.041 & 0.1 & 0.16 & -0.0435 & 0.12 \\
\hline 5 & 0.0125 & -0.0435 & 0.12 & 0.0125 & -0.0435 & 0.12 & 0.12 & -0.0435 & 0.12 \\
\hline 6 & 0.005 & -0.051 & 0.08 & 0.005 & -0.051 & 0.16 & 0.12 & -0.051 & 0.12 \\
\hline 7 & 0.03 & -0.026 & 0.26 & 0.055 & -0.001 & 0.28 & 0.5 & -0.0135 & 0.27 \\
\hline 8 & 0.015 & -0.041 & 0.12 & 0.02 & -0.036 & 0.1 & 0.32 & -0.0385 & 0.11 \\
\hline 9 & 0.025 & -0.031 & 0.16 & 0.02 & -0.036 & 0.14 & 0.26 & -0.0335 & 0.15 \\
\hline 10 & 0.088 & 0.032 & 0.32 & 0.095 & 0.039 & 0.3 & 0.86 & 0.0355 & 0.31 \\
\hline 11 & 0.035 & -0.021 & 0.14 & 0.01 & -0.046 & 0.08 & 0.18 & -0.0335 & 0.11 \\
\hline 12 & 0.035 & -0.021 & 0.12 & 0.015 & -0.041 & 0.08 & 0.24 & -0.031 & 0.1 \\
\hline
\end{tabular}

Step 4. Determine the average pit depth (wbar $\left.{ }_{a v g}\right)$.

The average pit depth was calculated with the following equation. 


\section{Page 62 of 69}

wbar $_{\mathrm{avg}}=\left(\Sigma\right.$ wbar $\left._{\mathrm{avg}, \mathrm{k}}\right) / \mathrm{n}$

where, $\mathrm{n}$ is the total number of pit couples. The average depth of all the pit couples was -0.031 inches.

Step 5. Determine the average diameter $\left(\mathrm{d}_{\mathrm{avg}}\right)$ and pit couple spacing $\left(\mathrm{P}_{\mathrm{avg}}\right)$.

The average pit diameter was calculated with the following equation.

$\mathrm{d}_{\mathrm{avg}} \quad=\left(\sum \mathrm{d}_{\mathrm{avg}, \mathrm{k}}\right) / \mathrm{n}$

The average diameter of all the pit couples was 0.157 inches.

The average pit diameter was calculated with the following equation.

$\mathrm{P}_{\mathrm{avg}}=\left(\Sigma \mathrm{P}_{\mathrm{k}}\right) / \mathrm{n}$

The average diameter of all the pit couples was 0.277 inches.

Step 6. Calculate the remaining strength factor (RSF)

The weld joint efficiency $\left(\mathrm{E}_{\mathrm{avg}}\right)$ is estimated with the following equations.

$$
\begin{aligned}
\mu_{\text {avg }} & =\left(\mathrm{P}_{\text {avg }}-\mathrm{d}_{\text {avg }}\right) / \mathrm{P}_{\text {avg }} \\
& =\left(0.277^{\prime}-0.157^{\prime}\right) / 0.277^{\prime} \\
& =0.434 ” \\
\mathrm{E}_{\mathrm{avg}} & =\sqrt{ } 3 / 2 \mu_{\mathrm{avg}} \\
& =0.376
\end{aligned}
$$

$$
\begin{aligned}
& \mathrm{RSF}_{\mathrm{pit}}=\min \left\{\left(1-\mathrm{wbar}_{\mathrm{avg}} / \mathrm{t}_{\min }+\left(\mathrm{E}_{\mathrm{avg}}\left(\mathrm{t}-\mathrm{FCA}-\mathrm{wbar}_{\mathrm{avg}}-\mathrm{t}_{\mathrm{min}}\right) / \mathrm{t}_{\mathrm{min}}\right), 1.0\right\}\right. \\
& =1-(-0.031 " / 0.154 ")+(0.376(0.24 "-0.030 "+(-0.031 ")-0.154 ") / 0.154 ") \\
& =1.26
\end{aligned}
$$

Therefore $\mathrm{RSF}_{\text {pit }}=1.0$.

The Level 1 criteria for acceptable damage are:

wbar $_{\text {avg }} \leq 0.0$ and RSF $=1.0$.

Therefore, continued use of the pipe is acceptable. 


\section{Page 63 of 69}

Step 7. Check limits on pit dimensions.

For each pit, $R_{t}$ must be greater than or equal to 0.20 where:

$\mathrm{R}_{\mathrm{t}}=\left(\mathrm{t}_{\min }-\mathrm{w}_{\mathrm{i}, \mathrm{k}}-\mathrm{FCA}\right) / \mathrm{t}_{\mathrm{min}}$

Example: Pit couple 1

$$
\begin{aligned}
R_{t} & =(0.154 ”-0.02 ”-0.03 ”) / 0.154 ” \\
& =0.675 "
\end{aligned}
$$

Twenty-three of the twenty-four pits met the criteria. One of the pits measured for pit couple \# 10 (i.e., the pit that was 0.095" deep) may penetrate through-wall within 60 years. Given that the intended future operating period was set as the time at which the deepest pit was expected to penetrate through-wall, it was not unexpected to see at least one of the pits to fail this criterion. If the intended future operating period was decreased to 56 years, all pits would have met the criteria.

To ensure that the pit is not actually a locally thinned area, each pit diameter must also meet the following requirement:

$\mathrm{d} \leq \mathrm{Q} \sqrt{ } \mathrm{D} \mathrm{t}_{\min }$

where Q was determined from Section 4 Table 4.4 of API 579. All pit couples satisfied this requirement.

The jacket is acceptable. Although the analysis was not performed at the time the pipe was inspected, it does confirm that the decision to leave the pipe in place was correct.

\subsection{Conclusions}

The performances of the H- and F-area tank farm transfer lines, both the core and jacket pipes were assessed. In general, the transfer line system piping has performed well for over fifty years. Although there have been instances of failures of the stainless steel core pipe during off-normal service, no significant degradation is anticipated during normal operations for a reasonable service life. General corrosion of stainless steel in high level waste environments was shown to be insignificant (i.e., little or no wall loss is expected for a time on the order of 180 years or more). Erosion is also not expected to limit the life of the pipes due to the low usage of the transfer lines and low fluid velocity during transfers. Quality controls on the material (e.g., corrosion evaluation testing) and procedures/specifications that limit contact with chloride bearing materials or liquids minimize the potential for the occurrence of stress corrosion cracking of the core pipe. 
General corrosion of the carbon steel jacket is not expected to be significant for a reasonable intended service life (e.g., on the order of 170 years). However, the carbon steel jackets are expected to continue to fail in local areas due to pitting corrosion. Life prediction estimates project that a significant increase in the number of jacket failures (i.e., through-wall penetrations) may occur after an additional 30 to 60 years of service life (i.e., between 2035 and 2065). A Fitness-For-Service evaluation was performed for a recently inspected jacket that showed evidence of pitting within a locally thinned area. The evaluation concluded that the line is still able to perform its intended function and can remain in service.

\subsection{Acknowledgements}

The author gratefully acknowledges the assistance of G. B. Rawls, C. F. Jenkins, G. A. Antaki, A. S. Plummer, and G. D. Thaxton in the preparation of this report.

\subsection{References}

1. R. L. Sindelar and B. J. Wiersma, "SRS High Level Waste Tank and Piping Systems - Structural Integrity Program and Topical Report”, WSRC-TR-95-0076, April 1995.

2. DOE Order 435.1, Radioactive Waste Management, July 9, 1999.

3. DOE Order 433.1, Maintenance Management Program for DOE Nuclear Facilities.

4. DOE High Level Waste Operation and Engineering Divisions Bi-Monthly Report, CST-02-02-002.

5. "Transfer Line Structural Integrity Assessment for the Tank Farms", Technical Assessment CST-04-12-002, January 2005.

6. B. J. Wiersma and P. E. Zapp, "Materials Degradation Evaluation of High Level Waste Transfer System”, WSRC-TR-96-0356, November, 1996.

7. B. J. Wiersma, "Assessment of the Potential for Corrosion of Type I Transfer Lines”, SRT-MTS-94-2008, March 23, 1994.

8. R. W. Yancey, "Waste Lines 241 F \&H", SEP-WM-165.1, February 15, 1979.

9. B. K. Roberts, R. E. Sprayberry, and G. A. McCaskey, "Failed Evaporator Bottoms Line", 200-H Area Metallurgical Report, August 8, 1979.

10. "Piping Flexibility Study of Waste Transfer Lines at Savannah River Plant", DPE3631, September, 1980.

11. F. H. Brown, "Waste Tansfer Lines", 200-F Area Metallurgical Report, July 12, 1977.

12. C. F. Jenkins, "Transfer Line Tank 19", 200-F Area Metallurgical Report, June $16,1980$.

13. H. E. Huckins and W. I. Thisell to A. E. Daking and E. A. Hein, "Waste Transfer Line from Tank 32 to Diversion Box 4", WR-860098, June 1, 1970.

14. Drawing No. W235672.

15. Drawing No. W2020535. 


\section{Page 65 of 69}

16. C. F. Jenkins to O. M. Morris, "Protective Coatings for Waste Management Underground Piping", September 8, 1980.

17. B. J. Wiersma, "Assessment of the Material Degradation of the Transfer Line Between HDB-5 and Tank 24”, HLW-STE-2000-00086, February 28, 2000.

18. Drawing Number W2020335.

19. R. W. Yancey, "Waste Lines 241 F \&H", SEP-WM-165.1, February 15, 1979.

20. R. H. Perry and C. H. Chilton, "Non-metallic Pipe and Lined Pipe Systems", in Chemical Engineers' Handbook, 5th ed., McGraw-Hill, New York, p. 6-79, 1973.

21. "Process, Utility and Building Service Piping", Specification No. 3018, Rev. 19, February 28, 1957.

22. "Process and Service Piping", Site Specification No. 4482, Rev. 106, September 21, 1990.

23. "Application of ASME B31.3”, Manual WSRC-IM-95-58, Engineering Guide No. 15060-G, Rev. 5, April 4, 2005.

24. "Practices to Minimize Chloride Stress-Corrosion Cracking of 300 Series Stainless Steel”, Site Specification No. 5992, Revision 6, April 30, 1986; Initial issue was September 14, 1971.

25. "Required Practices to Minimize Chloride Induced Stress Corrosion Cracking of Austenitic Stainless Steel”, Engineering Standard No. 05952, Revision 3, September 11, 2003.

26. "Corrosion Evaluation of Stainless Steels and Nickel-Based Alloys", Specification SW-800-M, June, 1988; Initial issue was March 1965.

27. "Corrosion Evaluated Stainless Steel and Corrosion Resisting Alloys", Savannah River Site Specification 4498, Rev. 9, January 31, 1989.

28. "Corrosion Evaluation: Stainless Steels and Other Corrosion Resistant Alloys", Engineering Standard No. 05951, Revision 4, March 23, 2005.

29. "Preventing Corrosion of Equipment by Water During Construction, Testing, and Storage", Specification SG-19-S, January 1989; Initial Issue was 1977.

30. "Maintenance Inspection Practices for Structures and Components", Engineering Guide No. 01101-G, Rev. 1, August 9, 2005.

31. "Austenitic Stainless Steel Tubing, Type 300 Series", Specification SW-300-M, August 1987; Initial issue was April, 1954.

32. H. D. Martin to G. M. Johnson, "Savannah River Plant Tank Farm Core Pipe Specifications", October 8, 1986.

33. "Corrosion Protection for Underground Piping", Site Specification 9543.

34. "Installation of Insulation to Underground Piping", Specification No. 5093, November 22, 1965.

35. “Thermal Insulation”, Specification No. 7196, Rev. 6, March 22, 1989; Initial issue January 16, 1980.

36. B. J. Wiersma and M. S. Shurrab, and T. C. Hsu, "An Assessment of Underground Steam System Failures in the Waste Tank Farms", WSRC-TR-950312, August 1995.

37. "Corrosion Protection of Underground Steel", Engineering Requirement No. 09900-05-R, February 28, 1993.

38. "Corrosion Protection - Underground Steel", Engineering Guide No. 09903-G, May 23, 2005. 


\section{Page 66 of 69}

39. E. D. D. During, Corrosion Atlas, $2^{\text {nd }}$ Edition, Elsevier, Amsterdam, 1991.

40. B. J. Wiersma and J. I. Mickalonis, "Corrosion Study of Replacement Materials for Hazardous Low Level Waste Processing Tanks”, WSRC-TR-91-138, March 1991.

41. A. J. Sedriks, Corrosion of Stainless Steels, $2^{\text {nd }}$ Edition, John Wiley and Sons, New York, 1996.

42. B. J. Wiersma, "Coupon Immersion Testing in Simulated Hazardous Low Level Waste", WSRC-TR-91-493, August 22, 1991.

43. G. T. Chandler, P. E. Zapp, and J. I. Mickalonis, "Hot-wall Corrosion Testing of Simulated High Level Nuclear Waste”, WSRC-MS-94-0367, 1994.

44. J. R. Davis, Understanding the Basics of Corrosion, ASM International, Materials Park, OH, 2000.

45. Z. Szklarska-Smialowska, Pitting and Crevice Corrosion, NACE International, Houston, TX, 2005.

46. M. H. Anderson and B. J. Wiersma, "Supplementary Safety System Corrosion Studies", WSRC-TR-91-389, May 1991.

47. R. S. Ondrejcin, "SRP Waste Compatibility with 304L Stainless Steel”, DPST-78303, April 12, 1978.

48. J. H. Phillips and W. J. Singley, Corrosion, Volume 15, p. 450t, 1959.

49. B. J. Wiersma, "Constant Extension Rate Tensile Tests on 304L Stainless Steel in Simulated Hazardous Low-Level Waste”, WSRC-TR-92-229, April 28, 1992.

50. A. J. Sedriks, Stress Corrosion Cracking Test Methods, NACE International, Houston, 1990.

51. A. S. Barab, "CTS Transfer Pit Soil Contamination, 241-F", Private Communication, July 18, 1975.

52. E. J. Majzlik, "Central Transfer System (CTS) Piping", 200 F-Area Metallurgical Report, January 14, 1977.

53. E. J. Majzlik, "Central Transfer System (CTS) Piping", 200 F-Area Metallurgical Report, May 12, 1976.

54. R. L. Hooker to A. S. Barab, "200-H Waste Management: Operation of H-CTS with PVC Taped Piping", Private Communication, July 30, 1975.

55. E. J. Majzlik, "Concentrate Transfer System (CTS) Piping", 200 H-Area Metallurgical Report, January 30, 1976.

56. R. L. Hooker and C. W. Jenkins to D. B. Jett, "Alternate Scope of Work for HCTS Repair", Private Communication, September 2, 1976.

57. C. F. Jenkins and R. E. Sprayberry, "Concentrate Transfer System (CTS) Loop, Cleanout Port No. 3 Failure", 200-H Area Metallurgical Report, August 10, 1982.

58. C. F. Jenkins and R. E. Sprayberry, "H-Area CTS Loop, Cleanout Port No. 3 Replacement", 200-H Area Metallurgical Report, July 14, 1983.

59. C. F. Jenkins and R. E. Sprayberry, "H-Area CTS Loop, Cleanout Port No. 3 Replacement", 200-H Area Metallurgical Report, August 16, 1983.

60. "CSTF Corrosion Control Program, Program Description Document," WSRCTR-2002-00327, Rev. 3, November 17, 2004.

61. C. F. Jenkins, "Common Causes of Material Degradation in Buried Piping", WSRC-TR-97-0089, May 1997.

62. M. R. Louthan, “Microbiologically Influenced Corrosion”, SRL-MTS-913076, 
November 21, 1991.

63. J. G. Stoecker, "Overview of Industrial Biological Corrosion: Past, Present, Future", in Biologically Induced Corrosion, S. C. Dexter, Ed., NACE International, Houston, TX, 1996.

64. A. A. Stein, "MIC Treatment and Prevention", in A Practical Manual on Microbiologically Influenced Corrosion, G. Kobrin, Ed., NACE International, Houston, TX, 1983.

65. J. I. Mickalonis, "Conditions for MIC in Transfer Lines”, SRT-MTS-99-20001, Rev. 2, March 31, 1999.

66. G. Kobrin, "Reflections on Microbiologically Induced Corrosion of Stainless Steel", in Biologically Induced Corrosion, S. C. Dexter, Ed., NACE International, Houston, TX, 1996.

67. C. F. Jenkins, "MIC - Corrosion in DWPF Melter Cooling Water System Piping", EES920043, February 7, 1992.

68. C. F. Jenkins, "Microbiologically-Influenced Corrosion Damage in a Water Coolant Header for Remote Process Equipment', at Corrosion '95, Paper No. 210, NACE International, Houston, TX, 1995.

69. C. F. Jenkins, "Parallel Plate Heat Exchanger Failure”, EES920191, June 23, 1992.

70. J. T. Gee, “Summary Report/MIC Inspections on Interarea Transfer Lines”, OPSDTE-93-0114, December 29, 1993.

71. Source Book on Industrial Alloy and Engineering Data, American Society for Metals, Metals Park, OH, 1978, p. 188.

72. P. E. Zapp, "Potential for Erosion Corrosion of Stainless Steel Components in the Late Wash Facility", SRT-MTS-94-2051, December 14, 1994.

73. D. T. Hobbs, "Characterization of the Tank 41H Saltcake Insoluble Solids", WSRC-RP-94-1213, October 31, 1994.

74. R. F. Miller, "Hardness vs. Wear", on http://www.cladtechnologies.com/Articles/Hardness\%20vs.\%20Wear/hardness.htm.

75. E. J. Freed and P. S. Mukherjee, "Tank 8 Waste Removal Operating Plan”, UESR-f-00009, Rev. 5, April 3, 2001.

76. H. D. Smith and M. R. Elmore, " Corrosion of Carbon Steel under Impinging Jets of Simulated Slurries of Neutralized Current Acid Waste (NCAW) and Neutralized Cladding Removal Waste (NCRW)”, PNL-7816, Pacific Northwest Laboratory, January, 1992.

77. G. R. Hoey and J. S. Bednar, "Erosion-Corrosion of Selected Metals in Coal Washing Plant Environments", Materials Performance, Vol. 22, p. 9, April, 1983.

78. W. S. Morrison, “DWPF Abrasion Tests Data Summary”, Project 1780, June 27, 1985.

79. G. T. Chandler and B. J. Wiersma, "Impact of DWPF Frit Carryover to High Level Waste Tank Farm”, SRT-MTS-95-2069, December 20, 1995.

80. J. T. Gee, "DWPF Materials Evaluation Summary Report”, WSRC-TR-96-0217, September, 121996.

81. Database for DWPF transfers to the Tank Farm on $\$ WG08\HLWWRT \DWPF\Transfer $\backslash$ dwpf.09.19.2005.xls.

82. J. E. Owen and R. W. Yancey to D. B. Jett, "Waste Transfer Lines Flexibility Study Status Report", April 3, 1981. 


\section{Page 68 of 69}

83. "Piping Flexibility Analysis for Tanks 4, 5, 6, and 8 to FDB-2", W718173, August 16, 1988.

84. M. Romanoff, Underground Corrosion, National Bureau of Standards Circular 579, National Bureau of Standards, Washington, D. C., 1957.

85. T. M. Sullivan, Assessment of Release Rates for Radionuclides in Activated Concrete, BNL-71537-2003, August 2003.

86. H. H. Uhlig, Corrosion and Corrosion Control, $2^{\text {nd }}$ ed., John Wiley and Sons, New York, New York, 1971.

87. Soil Survey of Savannah River Plant Area, Parts of Aiken, Barnwell, and Allendale Counties, South Carolina, a Publication of the National Cooperative Soil Survey, completed in 1987.

88. K. H. Subramanian, Corrosion Analysis for Tritium Extraction Facility Disposal in Pre-disposal Configuration, WSRC-TR-2005-00220, Westinghouse Savannah River Company, Aiken, South Carolina, May 2005.

89. W. L. Poe, "Leakage from Waste Tank 16", DP-1358, Aiken, South Carolina, November 1974.

89. Corrosion Survey Report, 200-F Separations Area At the Savannah River Plant, prepared by Ebasco, July 1982.

90. R. A. Corbett and C F. Jenkins, Soil Characteristics as Criteria for Cathodic Protection of a Nuclear Fuel Production Facility, Effects of Soil Characteristics on Corrosion, ASTM Special Technical Publication 1013, V. Chaker and J. D. Palmer, Eds., American Society of Testing and Materials, Philadelphia, Pennsylvania, 1989, pp. 95-106.

91. Corrosion Investigation And Feasibility Study of Cathodic Protection For Underground Waste Storage Tanks and Process Lines in H-Area At the Savannah River Plant, prepared by Harco Corporation, July 1982.

92. D'Appolonia, Report: DWPF - Stage I Investigation Pan of Excavation and Backfill, Submitted to E.I. DuPont De Nemours and Company, Aiken, South Carolina, September 1981.

93. P. W. Norris, "Evaluation of Operating Underground Waste Transfer Lines", Technical Review SR-92-747, September 14, 1992.

94. H-Area: "Pressure Testing of Waste Line Jackets", SW9.6-SVP-5, Revision 13, August 3, 2005; F-Area: "Pressure Testing of Waste Line Jackets", SW10.6-SVP5, Rev. 11, August 16, 2005.

95. B. J. Wiersma, "Evaluation of Non-Testable Transfer Lines Associated with FDB-2”, C-ESR-F-00037, October 27, 2005.

97 R. P. Krishnan, "Seismic Evaluation of HLW Underground Transfer Lines (U)", T-CLC-G-00092, Rev. 2, November 23, 1999.

98. M. J. Patek, Nondestructive Examination Condition Report, TSD-NDE-990737, November 8, 1999.

99. C. F. Jenkins, "FDB-2 Waste Transfer Line 108”, Equipment Engineering Department 200-F Area Metallurgical Report, July 18, 1980. 


\section{Page 69 of 69}

100. R. Krishnan, "Seismic Evaluation of HLW Underground Transfer Lines (U)", TCLC-G-00092, Rev. 3, October 19, 2005.

101. F. H. Brown, "Waste Transfer Lines", 200-F Area Metallurgical Report, July 12, 1977.

102. B. J. Wiersma and J. I. Mickalonis, "Galvanic Corrosion in Waste Tank Environments", WSRC-TR-2004-00580, December, 2004.

103. W. R. Hinz, Nondestructive Examination Condition Report, SRT-MTS-200360368, July 9, 2003.

104. R. J. Sunderland, Nondestructive Examination Condition Report, SRT-MTS2005-60506, August 24, 2005.

105. Fitness-For-Service, API Recommended Practice 579, First Edition, American Petroleum Institute, Washington, D. C., January, 2000.

106. R. P. Krishnan, "Evaluation of High Level Waste Tank Farm Transfer Lines of F\&H Areas", T-CLC-F-00143, October 19, 2005.

107. Standard Specification for Seamless, Welded, and Heavily Cold Worked Austenitic Stainless Steel Pipes, ASTM A 312/A 312M -05A, ASTM International, West Conshohocken, PA, 2005.

108. B. J. Wiersma, "Corrosion Assessment for Tanks 11 and 51 Following Tank 11 Waste Removal”, X-ESR-H-00044, September 12, 2005.

109. V. M. Patel, "Seismic Evaluation of Underground ITP Transfer Lines", T-CLCH-00327, November 16, 2005.

110. B. J. Wiersma, "Estimation of High Level Waste (HLW) Tank Remaining Service Life", WSRC-TR-2005-00196, May 2005.

111. M. Terry, et.al. "Expert Panel Workshop for Hanford Site Double-Shell Tank Waste Chemistry Optimization", RPP-RPT-22126, November 10, 2004.

112. Process Piping, ASME Code for Pressure Piping, B31, ASME B31.3-2004, ASME International, New York, NY, 2004.

113. R. A. Oakeley, "Explosion in a Transfer Line”, S-CLC-G-00234, May 13, 2002. 


\section{Appendix A: Summary of DOE Findings and WSRC Responses}

The Department of Energy - Savannah River Operations Office (DOE-SR) performed a comprehensive assessment of the structural integrity program for the Tank Farm waste transfer system at the Savannah River Site (SRS). The principal findings highlighted by the assessment were:

Finding \#1: Nominal wall thickness and not minimum wall thickness, is used to qualify piping for normal load cases. This design methodology must be assessed and justification provided for why using nominal thickness is still appropriate. (Deficiency \#CST-05-02-002-001)

Finding \#2: In-situ evidence exists that indicates at least some of the core piping and jacket piping wall thickness may be less than nominal. This evidence must be assessed and justification provided for why using nominal thickness is still appropriate.

(Deficiency \#CST-05-02-002-002)

Finding \#3: No provision for corrosion allowance was built into any of the 8 qualification calculations and no basis was provided for neglecting corrosion. (Deficiency \#CST-05-02-002-003)

Finding \#4: The potential wall thickness reduction mechanism of erosion due to sludge slurry transfers was not addressed in the calculations reviewed. (Deficiency \#CST-0502-002-004)

Finding \#5: No basis was provided as to why intergranular stress corrosion cracking (IGSCC) should be ignored in these seismic qualification analyses for the stainless steel core pipe. (Deficiency \#CST-05-02-002-005)

Washington Savannah River Company (WSRC) performed a separate evaluation of the structural integrity of the transfer system piping. The evaluation consisted of a review of the design of the transfer lines, potential degradation mechanisms, past inspection results, life expectancy calculations and a Fitness-For-Service evaluation. On the basis of this evaluation, the following is a summary of the responses to the DOE findings.

Finding \#1: Longitudinal stresses in piping systems are calculated based on nominal wall minus corrosion and erosion allowance and mechanical allowance (such as threads and grooves in the pipe wall). This finding questioned whether the mill tolerance should be accounted for in the stress analysis as well. Erosion and corrosion allowances are addressed in the Findings that follow. This response addresses mill fabrication tolerance.

a) In accordance with ASME B31.1 102.4 and B31.3 304.1, the mill tolerance, is utilized to select the pipe schedule.

b) Unlike corrosion allowance, mill tolerance is not used in calculating longitudinal stresses, per ASME B31.1 104.8.2 and B31.3 302.3.5(c). 


\section{Page ii of ix}

c) The following Inquiry confirmed the statement in b):

Interpretation: 6-03

Subject: ANSI/ASME B31.3-1984 Edition, Paras. 300(c)(5) and

302.3.5, and Appendix O;

Longitudinal Stresses and Longitudinal Bending Stresses, Sustained

Loads

Date issued: December 14, 1987

File: B3 1-87-022

Question (i): In accordance with ANSI/ASME B31.3, para.

302.3.5(c), when calculating the longitudinal stresses due to pressure, weight, and other sustained loads, should the thickness of pipe used in calculating longitudinal stresses be the nominal thickness minus mechanical, corrosion, and erosion allowances, but not minus the manufacturer's mill tolerance?

Reply (1): Yes.

Finding \#2: The in-situ evidence for the use of piping with less than nominal thickness was investigated. In one particular case, it had been reported that a 4" jacket had a wall thickness of 0.188 ". Standard 4" Schedule 40 pipe, typically utilized for jackets, has a wall thickness of 0.237 ". The value of 0.188 " had been utilized in the seismic qualification analysis. The original drawings and the ultrasonic inspection data associated with this line were reviewed. A note on the drawing indicated that the pipe had a nominal thickness of 0.156 ". The average measured wall thickness was 0.162 ", thus confirming the thickness stated on the drawing. Thus, there was no indication that there had been any significant wall thinning of the pipe. The seismic qualification analysis has been revised to reflect the actual nominal thickness of 0.156 ".

Inspections have also indicated that the pipe wall thickness at the extrados of elbows is slightly below the nominal. This observation was made for both the core and jacket piping. Wall thinning at this location occurs as the pipe is bent during fabrication. ASTM standard A312 specifically requires that the minimum allowable installed thickness is $87.5 \%$ of nominal. The majority of the data reviewed indicated that the wall thickness at the elbow is well above the minimum allowable installed thickness. All but one spot ultrasonic measurement on one jacket met the ASTM requirement. However, the difference between the measurement and the allowable thickness in this case is within the accuracy of the measurement technique.

Secondly, the possibility of significant wall thinning due to in-service degradation due to erosion and corrosion was addressed. As described in the responses below, significant general corrosion of either the core pipe or jacket is not anticipated for many years.

Finding \#3: SRS wastes are compatible with 300 series stainless steel materials. Wall thinning of the stainless steel core pipe due to general corrosion is expected to be insignificant for a reasonable intended service life (e.g., on the order of 180 years or more) for the following reasons:

a) The protective chromium oxide passive film on the surface of the steel is extremely stable in the moderate temperature and high $\mathrm{pH}$ environment of the high level waste at SRS.

b) Laboratory testing of 304L stainless steels in simulated high level waste indicated that general corrosion rates are extremely low. 


\section{Page iii of ix}

c) Visual inspection of portions of stainless steel core pipe that had been removed from service after 15 years indicated no significant wall thickness loss.

d) MIC degradation is primarily a localized phenomenon. No general wall thinning of the material occurs, but rather pin-hole penetrations near welds in the pipe. Thus this mechanism would not impact the nominal wall thickness of the transfer line piping utilized for the structural calculations.

Protective coatings and/or thermal insulation prevent significant general corrosion of the exterior surface of the carbon steel jacket. Visual inspection of sections of jacket piping that were removed from service after 15 years indicated no significant wall thickness loss. Isolated failures of jacket piping have occurred due to:

a) Pitting of the carbon steel jacket occurs at defects (i.e., holidays) in a protective coating.

b) Corrosion of the carbon steel jacket occurs in local areas beneath thermal insulation that has been disturbed.

Small pin-hole penetrations may form on the exterior of the jacket at these isolated areas. The life expectancy of carbon steel jackets was estimated based on an actual case of pitting damage within a region of local thinning. Two failure mechanisms were considered: 1) wall loss due to general corrosion and 2) through-wall penetration due to pitting corrosion. Based on general corrosion rates, the wall thickness of the jackets will be sufficient for any reasonable service life (e.g.,on the order of 170 years or more). Pits on the other hand were estimated to penetrate through wall after 80 years of service. Therefore, through-wall penetration due to pitting corrosion would be the life limiting mechanism for the carbon steel jacket. The transfer lines have been in-service for approximately 20 to 50 years. Thus, occasions when the transfer lines fail the jacket pressure test are expected to begin to increase more significantly sometime between the years 2035 to 2065 .

Finding \#4: The transfer of sludge during waste removal operations or sludge and glass frit particles from the DWPF recycle stream through the stainless steel core pipe is not a significant erosion concern for the following reasons:

a) Low number of sludge or DWPF transfers performed.

b) The sludge particles are relatively non-abrasive.

c) Relatively low fluid velocities (i.e., less than $7.5 \mathrm{ft} / \mathrm{s}$ )

d) The concentration of the more abrasive glass frit particles in the DWPF recycle stream is relatively low.

e) Results from erosion tests in pilot facilities at SRS indicate that erosion is not expected to be significant.

f) Piping systems in other facilities at SRS (e.g., DWPF), constructed of similar materials to the waste transfer piping, that have handled waste streams with sludge and glass frit have been inspected visually and with ultrasonic measurements and show no evidence of erosion.

g) There have been no known failures of core piping due to erosion in the tank farm.

Wall thinning of the stainless steel core pipe due to erosion will likely be insignificant for a reasonable intended service life (e.g., on the order of 160 years or more). The carbon steel jackets are not exposed to a flowing stream, and therefore erosion is not a concern. 
Finding \#5: Failure of the transfer line core pipe due to IGSCC is highly unlikely for the following reasons:

a) Laboratory tests performed in simulated high level waste environments indicated that $304 \mathrm{~L}$ stainless steel is not susceptible to IGSCC.

b) IGSCC of a 300 series stainless steel requires a heavily sensitized microstruture that is susceptible to intergranular attack. Corrosion evaluation testing is performed to assess the susceptibility to intergranular attack and hence degree of sensitization. Successful completion of this test on samples of the stainless steel utilized for the transfer piping has been required since 1965.

c) Prior to 1965 , welded pipe was required per site specification to be solution annealed prior to being placed in service. Solution annealing homogenizes the microstructure of the material, thus minimizing the susceptibility of the grain boundary regions to IGSCC.

Transgranular stress corrosion cracking (TGSCC) of the core pipe has been observed in situations where the lines were exposed for extended periods of time to natural water $(\mathrm{pH}$ 2-8) that contained chlorides. Inadvertent elevated temperature in the vicinity of the pipe was also a contributing factor. The piping in these locations where this has occurred has either been replaced or has been retired from service. Administrative controls are in place to minimize the possibility of developing the off-normal conditions at other locations.

Other issues related to the structural integrity of the transfer lines, but not specifically addressed in the findings are summarized briefly below.

\section{Stainless Steel Core Piping}

a) Localized attack of stainless steel, such as pitting or microbiologically induced corrosion, can significantly reduce the life expectancy of the core pipe. Neither of these mechanisms is anticipated during normal operation of the transfer lines. These types of attack are possible if off-normal conditions (e.g., pipe contains uninhibited water) are allowed to exist for extended periods of time. Administrative controls are in place to minimize the potential for this type of attack.

b) One core pipe failed due to thermal fatigue. A comprehensive piping flexibility study was performed to identify other potentially susceptible lines. Recommendations were implemented to minimize the amplitude of the thermal cycle and associated thermal stresses that these lines experience.

b) Life expectancy calculations determined the time at which the wall thickness is less than the minimum required to survive a design basis seismic event. 


\section{Page $v$ of ix}

\section{Carbon Steel Jacket Piping}

A Fitness-For-Service evaluation was performed for a jacket that showed evidence of pitting within a locally thinned area. The evaluation concluded that the line is able to perform its intended function and can remain in service.

\section{Monitoring and Inspection}

a) A jacket pressure test is performed within two years prior to use to monitor the jacket and core pipe for through-wall penetration. For piping where the jacket pressure test is not possible, an evaluation of the potential for material degradation is performed to examine the risks associated with utilizing the pipe for waste transfer.

b) Helium testing is performed to locate the through-wall penetration. In many instances pits are not discovered on the jacket, but rather in jacket vents, jacket drain lines or dip tubes for the leak detection box. These failures occur earlier than the jacket due to a thinner wall. 
WSRC-TR-2005-00532

March, 2006

Page vi of ix

\section{Appendix B: Calculation Methodology for Determining the Minimum Required Wall Thickness}

An iterative, shell program that utilized MATHCAD ${ }^{\mathrm{TM}}$ was developed to calculate the minimum required wall thickness for a pipe due to an applied bending load. The program employs the maximum stress in the piping and determines the applied moment based on the full section modulus of the piping section. The program then determines the minimum required section modulus that will produce a maximum stress state in the piping equal to the maximum code allowable stress. The wall thickness that results in the minimum required section modulus is defined as the minimum required piping wall thickness necessary to support the applied bending moment.

The example calculation below is for a 10" schedule 20 waste transfer line jacket pipe (Line \#1663).

Input:

$\begin{array}{lllll}\mathrm{OD} & = & \text { Outside Diameter } & = & 10.75 ” \\ \mathrm{ID} & = & \text { Inside Diameter } & = & 10.25 ” \\ \mathrm{Z} & = & \text { Full Section Modulus } & = & 21.15 \\ \sigma & = & \text { Maximum Stress } & = & 36.49 \mathrm{ksi}[109]\end{array}$

Step 1: Calculate the required moment in the piping.

The following equation is utilized to calculate the bending moment, $\mathrm{M}$ :

$\mathrm{M}=1000 * \sigma * \mathrm{Z}$

$\mathrm{M}=771,764$ in-lbs

The pressure term is not applied because the jacket piping is at ambient conditions. The location being evaluated is in a straight section of piping and therefore the stress intensification factor is 1 .

Step 2: Calculate the allowable stress.

The allowable stress (S) as defined by ASME B31.3 [112] is:

$\mathrm{S}=\min \left\{3 * \mathrm{~S}_{\mathrm{h}}, 2 * \mathrm{~S}_{\mathrm{y}}\right\}$

$\mathrm{S}_{\mathrm{h}}=$ Allowable stress at maximum metal temperature $=20 \mathrm{ksi}$

$\mathrm{S}_{\mathrm{y}}=$ Yield Strength $=35 \mathrm{ksi}$

Therefore, $\mathrm{S}=60 \mathrm{ksi}$. 


\section{Page vii of ix}

Step 3: Calculate the minimum required section modulus.

The following equation is used to calculate the minimum required section modulus, $Z$ ':

$Z^{\prime}=M / S$

$\mathrm{Z}^{\prime}=(771,764 \mathrm{in}-\mathrm{lb}) /\left(60,000 \mathrm{lb} / \mathrm{in}^{2}\right)=12.863 \mathrm{in}^{3}$

Step 4: Determine the required minimum wall thickness that provides the minimum required section modulus.

a) Guess a value for the OD. The OD will decrease due to corrosion on the exterior of the jacket.

b) Calculate the outside radius (OR) and the inside radius (IR).

$$
\mathrm{OR}=\mathrm{OD} / 2
$$

$\mathrm{IR}=\mathrm{ID} / 2$

c) Calculate Z' from the following equation:

$$
\mathrm{Z}^{\prime}=\pi / 4 *\left(\mathrm{OR}^{4}-\mathrm{IR}^{4}\right) / \mathrm{OR}
$$

d) Compare the Z' calculated from Equation A.6 with that from Equation A.3. If they are equal, proceed to Step 5. Else, go back to a) and guess a new value for OD.

Step d) was satisfied when OD 10.557”.

Step 5: Calculate the required wall thickness, $t_{\min }$.

$$
\begin{aligned}
& \mathrm{t}_{\text {min }}=\mathrm{OR}-\mathrm{IR} \\
& \mathrm{t}_{\min }=5.279 "-5.125^{\prime \prime}=0.154 "
\end{aligned}
$$




\section{Appendix C: Calculation of Life Expectancy for Stainless Steel Core Pipe Considering Erosion Due to Sludge Slurry or DWPF Recycle Waste}

The five cases not shown in the body of the text are shown here.

1) 3" Schedule 10 pipe exposed to sludge slurry from Tank 40 to the Low Point Pump Pit.

Inputs:

$\mathrm{C}_{\mathrm{A}}=0.030 "$

$\mathrm{E}_{\mathrm{R}}=0.0004 \% / \mathrm{yr}$

$\mathrm{U}_{\mathrm{E}}=0.006$

$\mathrm{C}_{\mathrm{R}}=0.000078 \% / \mathrm{yr}$

$\mathrm{U}_{\mathrm{C}}=0.994$

$\tau=(0.030$ inches $) /(0.0004$ inches $/ \mathrm{yr} * 0.006+0.000078$ inches $/ \mathrm{yr} * 0.994)$ $=\quad 375$ years

2) 3" Schedule 10 pipe exposed to DWPF Recycle from the Low Point Pump Pit to HDB5 .

Inputs:

$\mathrm{C}_{\mathrm{A}}=0.030$ "

$\mathrm{E}_{\mathrm{R}}=0.0002 \% / \mathrm{yr}$

$\mathrm{U}_{\mathrm{E}}=0.012$

$\mathrm{C}_{\mathrm{R}}=0.000078 \% / \mathrm{yr}$

$\mathrm{U}_{\mathrm{C}}=0.988$

$\tau=(0.030$ inches $) /(0.0002$ inches $/ \mathrm{yr} * 0.012+0.000078$ inches $/ \mathrm{yr} * 0.988)$ $=378$ years

3) 3" Schedule 40 pipe exposed to sludge slurry from HDB-7 to Tank 51.

Inputs:

$\mathrm{C}_{\mathrm{A}}=0.014$ "

$\mathrm{E}_{\mathrm{R}}=0.0004 \% / \mathrm{yr}$

$\mathrm{U}_{\mathrm{E}}=0.027$

$\mathrm{C}_{\mathrm{R}}=0.000078 \% / \mathrm{yr}$

$\mathrm{U}_{\mathrm{C}}=0.973$

$\tau=(0.014$ inches $) /(0.0004$ inches $/ \mathrm{yr} * 0.027+0.000078$ inches $/ \mathrm{yr} * 0.973)$

$=161$ years 
Page ix of ix

4) 3" Schedule 40 pipe exposed to sludge slurry from Tank 40 to the Low Point Pump Pit.

Inputs:

$\mathrm{C}_{\mathrm{A}}=0.014$ '”

$\mathrm{E}_{\mathrm{R}}=0.0004 \% / \mathrm{yr}$

$\mathrm{U}_{\mathrm{E}}=0.006$

$\mathrm{C}_{\mathrm{R}}=0.000078 \% / \mathrm{yr}$

$\mathrm{U}_{\mathrm{C}}=0.994$

$\tau=(0.014$ inches $) /(0.0004$ inches $/ \mathrm{yr} * 0.006+0.000078$ inches $/ \mathrm{yr} * 0.994)$ $=175$ years

5) 3" Schedule 40 pipe exposed to DWPF Recycle from the Low Point Pump Pit to HDB5 .

Inputs:

$\mathrm{C}_{\mathrm{A}}=0.014$ "

$\mathrm{E}_{\mathrm{R}}=0.0002 \% / \mathrm{yr}$

$\mathrm{U}_{\mathrm{E}}=0.012$

$\mathrm{C}_{\mathrm{R}}=0.000078 \% / \mathrm{yr}$

$\mathrm{U}_{\mathrm{C}}=0.988$

$\tau=(0.014$ inches $) /(0.0002$ inches $/ \mathrm{yr} * 0.012+0.000078$ inches $/ \mathrm{yr} * 0.988)$

$=176$ years 
Distribution:

DOE-SR

M. A. Mikolanis, 707-H

M. P. Dholakia, 707-H

B. J. Gutierrez, 707-H

D. J. Blake, 707-H

T. C. Temple, 707-H

WSRC

V. G. Dickert, 766-H

W. I. Lewis, 766-H

D. B. Little, 703-H

J. P. Schwenker, 703-H

G. D. Thaxton, 703-H

A. S. Plummer, 703-H

E. J. Freed, 703-H

D. J. Martin, 703-H

W. L. Isom, 766-H

N. F. Chapman, 703-H

J. J. Phillips, 703-H

M. W. Loibl, 704-24S

D. C. Bumgardner, 704-26F

N. C. Iyer, 773-41A

G. T. Chandler, 773-A

R. L. Sindelar, 773-41A

G. B. Rawls, 773-41A

C. F. Jenkins, 730-A

G. A. Antaki, 730-1B

W. N. Kennedy, 730-1B 